
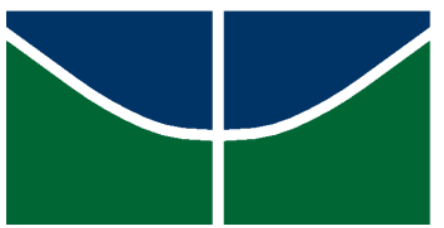

Universidade de Brasília

Instituto de Ciências Humanas - IH

Departamento de Serviço Social - SER

Programa de Pós-Graduação em Política Social - PPGPS

TESE DE DOUTORADO

O ACESSO, POSSE E CONTROLE DA TERRA DAS MULHERES RURAIS NAS COMUNIDADES DO DISTRITO DE INHARRIME

Maria Albertina Gomes Chale Chambe

Brasília, março de 2016 


\section{O ACESSO, POSSE E CONTROLE DA TERRA DAS MULHERES RURAIS NAS COMUNIDADES DO DISTRITO DE INHARRIME}

Tese de doutorado apresentada ao Programa de Pós-Graduação em Política Social do Departamento de Serviço Social da Universidade de Brasília (PPGPS/UnB) como requisito parcial para a obtenção do grau de Doutora em Política Social.

Orientador: Prof. Dr. Newton Narciso Gomes Junior (PPGPS/SER/UnB) 
Ficha catalográfica elaborada automaticamente, com os dados fornecidos pelo(a) autor(a)

$\mathrm{Ca}$

Chale Chambe, Maria Albertina Gomes

O ACESSO, POSSE E CONTROLE DA TERRA DAS MULHERES RURAIS NAS COMUNIDADES DO DISTRITO DE INHARRIME / Maria Albertina Gomes Chale Chambe; orientador Newton Narciso Gomes Junior. -- Brasília, 2016. $125 \mathrm{p}$.

Tese (Doutorado - Doutorado em Política Social) -Universidade de Brasília, 2016.

1. Acesso, Posse e Controle de Terra. 2.

Comunidade Rural. 3. Mulheres. 4. Moçambique. I. Gomes Junior, Newton Narciso, orient. II. Título. 


\section{BANCA EXAMINADORA}

Prof. Dr. Newton Narciso Gomes Junior

(Orientador - PPGPS/SER/UnB)

$$
\text { Prof. }{ }^{a} \text { Dr. }{ }^{a} \text { Débora Diniz }
$$
$(\mathrm{SER} / \mathrm{UnB})$

Prof. Dr. Marcelo Carvalho Rosa

$(\mathrm{UnB})$

Prof. Dr. José Rossini Campos Couto Corrêa (UDF/UniCEUB)

Prof. Dr. Sérgio Sauer (FUP/UNB) 
Em especial às minhas filhas (Miriam e Mirela), que me fizeram mãe.

Ao meu marido (Afonso Chambe), o meu suporte, o meu amor.

Ao meu pai (in memoriam) e minha mãe (Odete). 


\section{AGRADECIMENTOS}

Em especial agradeço ao meu marido, Afonso Chambe, pelo apoio e participação direta em todos momentos, bons e ruins, da minha vida acadêmica e especialmente neste trabalho. Muito obrigada, marido. Mais uma vez, fizeste-te presente no decurso das minhas pesquisas. Mais uma vez acompanhaste-me incondicionalmente e desta vez tivemos a companhia das nossas duas meninas. Pela minha constante ausência, tornaste-te pai e mãe delas quando mais precisei. Foste o marido, o pai presente das meninas e não o ajudante da esposa, o ajudante da mãe das tuas filhas.

Agradeço de coração à minha família (minha mãe, irmãos, irmãs, cunhados e sobrinhos), que são o meu suporte, meu porto seguro. Especialmente, as minhas palavras vão para minha irmã Ilda Marinela, carinhosamente tratada por "Nela". A tia "Nenha" de Miriam e Mirela. Foste uma ajuda extremamente importante. Resolveste detalhes do trabalho que me ajudaram a cumprir com os prazos. Foste a tia presente para esta mãe desesperada. Por isso e muito mais, muito obrigada, irmã. À minha irmã Maria de Lourdes, a "tia Nonoca". Mais uma vez mostraste o sentido de se ter uma família, de se ter uma irmã. Saíste do conforto do teu lar para cuidar das minhas filhas enquanto estive ausente a defender este trabalho. Por isso, não só eu, mas todos nós, dizemos: muito obrigada.

Vai meu especial agradecimento para o meu orientador, professor Newton Narciso Gomes Júnior, pela parceria e amizade acima de tudo. Pela compreensão nos momentos de falhas. Pelos momentos de "saia justa" que, com certeza, passou comigo. Pela confiança e acima de tudo, por acreditar em mim mesmo quando eu já não via nenhuma esperança para o término deste trabalho. E com tudo isto, não deixaria de agradecer aos professores Sérgio Sauer e Marcelo Rosa, que foram os professores que 
me examinaram no mestrado e os que me incentivaram a ingressar no doutorado. À professora Débora Diniz, pelo apoio e compreensão demostrados durante as minhas gestações enquanto sua aluna. Pela admiração que tenho para com todos, que com certeza foram a minha fonte de inspiração para a conclusão deste doutorado. Por isso, muito vos agradeço, professores.

Agradeço, ainda, ao professor Perci Coelho pela disponibilidade.

Agradecimentos especiais vão para a minha empregada doméstica, Elisa. Pedi-a que viesse ao Brasil apoiar-me com as meninas e a casa. Para isso, deixou o marido e as filhas, que também precisavam de apoio da esposa, da mãe por perto. Palavras me faltariam para dizer o quanto apreciei o gesto, o empenho e o cuidado que teve com todos nós.

E, por fim, e não menos importante, agradeço a todos participantes diretos da pesquisa de campo. À Ilda Banze, pela exposição a que estará sujeita para todo o sempre com a aprovação deste trabalho. Por permitir-me entrar em sua cerimônia de lobolo e fazer as imagens que trago algumas expostas no trabalho, pelas traduções, por tudo, muito obrigada. Aos chefes comunitários, aos representantes das instituições governamentais e privadas e a todas as famílias que me receberam. Particularmente, às mulheres que abriram seus corações e contaram-me seus sentimentos mais íntimos, seus temores, suas angústias, suas estórias de vida privada. Estes últimos anos de convivência juntas foram especiais e igualmente importantes para que este trabalho se concretizasse.

A todos, os meus mais sinceros agradecimentos. 


\section{LISTA DE SIGLAS}

ABC - Agência Brasileira de Cooperação

BI - Bilhete de Identidade

BIRD - Banco Internacional de Reconstrução e Desenvolvimento

BM - Banco Mundial

BRIC - África do Sul, Brasil, Rússia, Índia e China

CARE - Organização Humanitária Internacional

CEA - Centro de Estudos Africanos

CEPAL - Comissão Económica para América Latina

CID - Cooperação Internacional para o Desenvolvimento

DIRE - Documento de Identificação de Residentes Estrangeiros

DUAT - Direito e uso do aproveitamento de terra

EMBRAPA - Empresa Brasileira de Pesquisa Agropecuária

EUA - Estados Unidos da América

FRELIMO - Frente de Libertação de Moçambique

FMI - Fundo Monetário Internacional

GATT - Acordo Geral Sobre Tarifas Económicas

HIV-SIDA - Síndroma de Imunodeficiência adquirida

IESE - Instituto de Estudo Económicos e Sociais

IIAM - Instituto de Investigação Agrária de Moçambique

INCAJU - Instituto do Fomento de Caju

iTC - Iniciativa para Terras Comunitárias

JICA - Agencia de Cooperação Internacional do Japão

OMC - Organização Mundial do Comércio 
OMM - Organização da Mulher Moçambicana

PIB - Produto Interno Bruto

PRES - Programa de Reabilitação Económica e Social

PROSAVANA - Programa de Desenvolvimento da Agricultura

RENAMO - Resistência Nacional de Moçambique

SPGC - Serviços Provinciais de Geografia e Cadastro

UEM - Universidade Eduardo Mondlane

UNB - Universidade de Brasília

UNESCO - Organização das Nações Unidas para a Educação, Ciência e Cultura 


\section{LISTA DE FIGURAS}

Figura 1. Mapa de Moçambique

Figura 2. Mapa do distrito de Inharrime

Foto1. Assistindo a uma cerimonia de casamento em setembro de 2013

Foto 2. Atividades festivas

Foto 3. Elementos do grupo focal

Foto 4. Exemplo de uma nyumba

Foto 5. Um momento da cerimonia de adoração aos antepassados

Foto 6. Parte dos requisitos exigidos para a cerimónia do lobolo

Foto 7. Momento de entrega do dinheiro do lobolo por parte da noiva 


\section{GLOSSÁRIO}

Apwiyanwene/nihimo - irmã mais velha do regulo.

Awiyamwene - rainha confiada para a resolução dos problemas da comunidade. Cacana

- planta usada como alimento e para uso medicinal.

Chichope - língua falada pelo grupo étnico chope.

Chope - grupo étnico e língua da região sul de Moçambique.

Deliver - termo usado pelas mulheres de Inharrime para se referir ao veículo transportador de trabalhadores/e/ou suas bagagens/encomendas oriundos da África do Sul.

Dithevele - tronco para destilação de aguardente.

Feijão Nhemba - um tipo de feijão semelhante ao feijão verde.

Hikombela mati - estamos a pedir água (para dizer pedir mão de entrada).

Joni - termo usado no sul de Moçambique para se referir a África do Sul.

Ku ti thopa/Ku hlambaya - evocação dos antepassados.

Lobolo/Lowola - casamento tradicional.

Machamba - parcela de terra para a prática da agricultura.

Machope - pessoa de origem chope (oriunda das províncias de Gaza, ao norte e Inhambane, ao sul).

Madoda - pessoa mais velha de um grupo ou família.

Mafurra (Mtona/Munyanzi) - sementes oleaginosas extraídas da mafurreira.

Mathapa - prato na base de folhas de mandioca com amendoim, coco, caranguejo ou camarão.

Matolo - unguento extraído da mafura usado no tratamento de parturientes.

Mbila/Timbila - instrumento para danças tradicionais.

Muphahlu - evocação dos antepassados feito por um elemento mais velho da família, preferencialmente homem.

Ndzanga-machado pequeno. 
Nhandibande - o homem da terra.

Nyumba - casa, palhota feita de caniço ou capim.

Pahlar - rito tradicional que simboliza apresentação das preocupações.

Status - elemento de diferenciação.

Si beso - designação de enxoval de bebê.

Tinhloco - cabeças.

Vahiside /Vamwalede - desaparecer, na língua chope.

Wa hombe - pessoa com autoridade.

Wanhwani - fulano de determinada família/casa.

Wukhwena/in sungi - ritos tradicionais de circuncisão.

Xibalo - trabalho forçado.

Xiguiane - entrega da noiva e seus pertences, após o casamento, à casa do noivo.

Xiguinha - prato na base de mandioca, feijão, coco e amendoim. 


\section{RESUMO}

O objetivo principal da tese é discutir a questão da terra focando os problemas que as mulheres enfrentam para o acesso, posse e controle da terra junto às comunidades tradicionais onde estão inseridas. Sabe-se que, em Moçambique, o meio rural possui uma notória participação das mulheres nas atividades produtivas, que garante, além da segurança alimentar das suas famílias, a sustentabilidade da economia rural moçambicana num todo, bem como a reprodução social das comunidades rurais. Não é à toa que esta mulher encontra-se envolvida em um mundo tradicional culturalmente rico, em que, ao mesmo tempo em que exerce uma proteção sobre ela e sua família, pode representar uma forma de exclusão e um elemento limitante para o acesso aos recursos junto as suas comunidades. É nesse contexto que o argumento principal levantado no trabalho é de que, quaisquer que sejam os constrangimentos que as mulheres enfrentem para exercerem o controle de sua vida e ter acesso aos recursos fundamentais para a sua sobrevivência, existem formas de contornar, sem no entanto confrontar e questionar os preceitos das tradições e culturas, de modo que garantam e mantenham para elas o acesso, a posse e o controle da terra e outros bens, em caso de necessidade. Afinal, existem relações sociais que são mecanismos bem mais fortes de reprodução hierárquica e de submissão para com as mulheres e que definem os tradicionais papéis para a mulher e para o homem dentro das comunidades rurais. Neste contexto, sendo a terra um recurso produtivo bastante almejado no mundo capitalista em que nos encontramos envolvidos, não se poderia deixar de fora uma análise da posição em que Moçambique se encontra dentro dele, pelo que são mostrados os mecanismos de dependência externa econômica e como esta transita para o mundo social da sociedade, gerando ao mesmo tempo uma certa forma de dependência social. Por isso, descortinam-se ainda as riquezas culturais das comunidades que compõem o grande Moçambique, mostrando o posicionamento da mulher, bem como as formas que estas apresentam-na como forma de adquirir os recursos e aceder à terra, afinal, no fim das contas, são essas tradições, culturas, hábitos e costumes que exercem influência na atuação da mulher junto à família e que determinam em que condições esta poderá ter acesso aos recursos.

Palavras-chave: Acesso, Posse e Controle de Terra, Comunidade Rural, Mulheres, Moçambique. 


\begin{abstract}
The main aim of the thesis is to discuss the land issue focusing on the problems that women face to have access, ownership and control that the land next to the traditional communities where they are inserted. It is known that in Mozambique the rural area has remarkable participation of women in productive activities that ensure, besides food security of their families, the sustainability of Mozambican rural economy as a whole, as well as the social reproduction of rural communities. No wonder that this woman, is involved in a rich traditional world culturally, that in the same time that exerts a protection about her and her family, can represent a way of exclusion and limited element to access the resources near their communities. It is in this context that the main argument raised in the work is that whatever the constraints that women faces to exercise the control of their life and to have access to the main resources for their survive, there is ways of turn around without confront and question the traditional and cultural principles, in way to ensure and maintain for them the access, the ownership, and control of the land and other goods in case of necessity. after all, there is social relations that are stronger mechanism of hierarchical reproduction and submission to women and define the traditional role for woman and for man inside the rural communities. In this context, being the land a productive resource very target in the capitalist world where we are involved, we can't left out an analyze of the position that Mozambique is within it, therefore are shown the mechanism of economic external dependence and how this transits to social world of society, generating at the same time a certain way of social dependence. That is why, are still revealed the cultural wealth of the communities that compose the great Mozambique, shown the woman positioning, as well as the ways that they present it is a way to acquire resources and access to land, after all are these traditions, cultural, habits and costumes that exert influence in the woman's performance inside the family and determine in which condition she can have access to the resource.
\end{abstract}

Keywords: Access, Ownership and Control of the Land, Rural Community, Women, Mozambique. 
INTRODUCÃO

Procedimentos Metodológicos $\quad 10$

LOCAL DE ESTUDO

ETAPAS DA PESQUISA

CONSIDERAÇõES GERAIS SOBRE O MÉTODO DE PESQUISA

$\begin{array}{ll}\text { ESTRUTURA DA TESE } & 27\end{array}$

CAPITULO I - A TEORIA DA DEPENDÊNCIA E DEPENDÊNCIA EM \begin{tabular}{lr} 
MOCAMBIQUE & 28 \\
\hline
\end{tabular}

INTRODUÇÃO 28

1.1. OS PRECEITOS DA TEORIA DA DEPENDÊNCIA 29

1.2. A GÊNESE DA DEPENDÊNCIA EM MOÇAMBIQUE E SEU IMPACTO NAS RELAÇÕES COMUNITÁRIAS 36

1.3. A CONTINUIDADE DO ESTADO DE DEPENDÊNCIA

1.4. CONSEQUÊNCIAS DA DEPENDÊNCIA EXTERNA NO MEIO RURAL

CONCLUSÃO $\quad 50$

CAPÍTULO II - A ORIGEM E FORMACX̃̃O DA FAMÍLIA

INTRODUÇÃO

2.1. A ORIGEM DA FAMÍlIa

2.2. A PERSPECTIVA AFRICANA DE FAMÍLIA

2.3. A FaMília EM MOÇAMBiQUe

2.3.1. AS COMUNIDADES COM PREDOMINÂNCIA MATRILINEAR: O EXEMPLO DOS MACUALOMWE $\quad 62$

2.3.2. AS COMUNIDADES DE PREDOMINÂNCIA PATRILINEAR 65

$\begin{array}{ll}\text { CONCLUSÃO } & 79\end{array}$

CAPÍTULO III - AS FORMAS DE ACESSO, POSSE E CONTROLE DE

\begin{tabular}{lr} 
TERRA EM MOCAMBIQUE & 81 \\
\hline
\end{tabular}

$\begin{array}{ll}\text { INTRODUÇ̃̃OO } & 81\end{array}$

3.1. O CONTEXTO GERAL DA QUESTÃo FUNDIÁRIA NO DOMÍNIO COMUNITÁRIO $\begin{array}{ll}\text { RURAL } & \mathbf{8 1}\end{array}$

3.1.1. A EVOLUÇ̃̃o HISTÓRICA DO ACESSO, POSSE E CONTROLE DA TERRA 83

3.2. A AUTORIDADE TRADICIONAL COMO ELEMENTO CENTRAL NA POSSE DE TERRA

3.3. MECANISMOS DE CONTROLE E POSSE DA TERRA EM MOÇAMBIQUe

3.4. O ACESSO A TERRA $\quad 102$

3.4.1. ACESSO POR HERANÇA 102

3.4.2. ACESSO PELO CASAMENTO 105

3.4.3. ACESSO POR EMPRÉSTIMO $\quad 112$

$\begin{array}{ll}\text { CONCluSão } & 114\end{array}$

CONSIDERACÕES FINAIS $\quad 115$

REFERÊNCIAS 


\section{INTRODUÇÃO}

Figura 1: Mapa de Moçambique

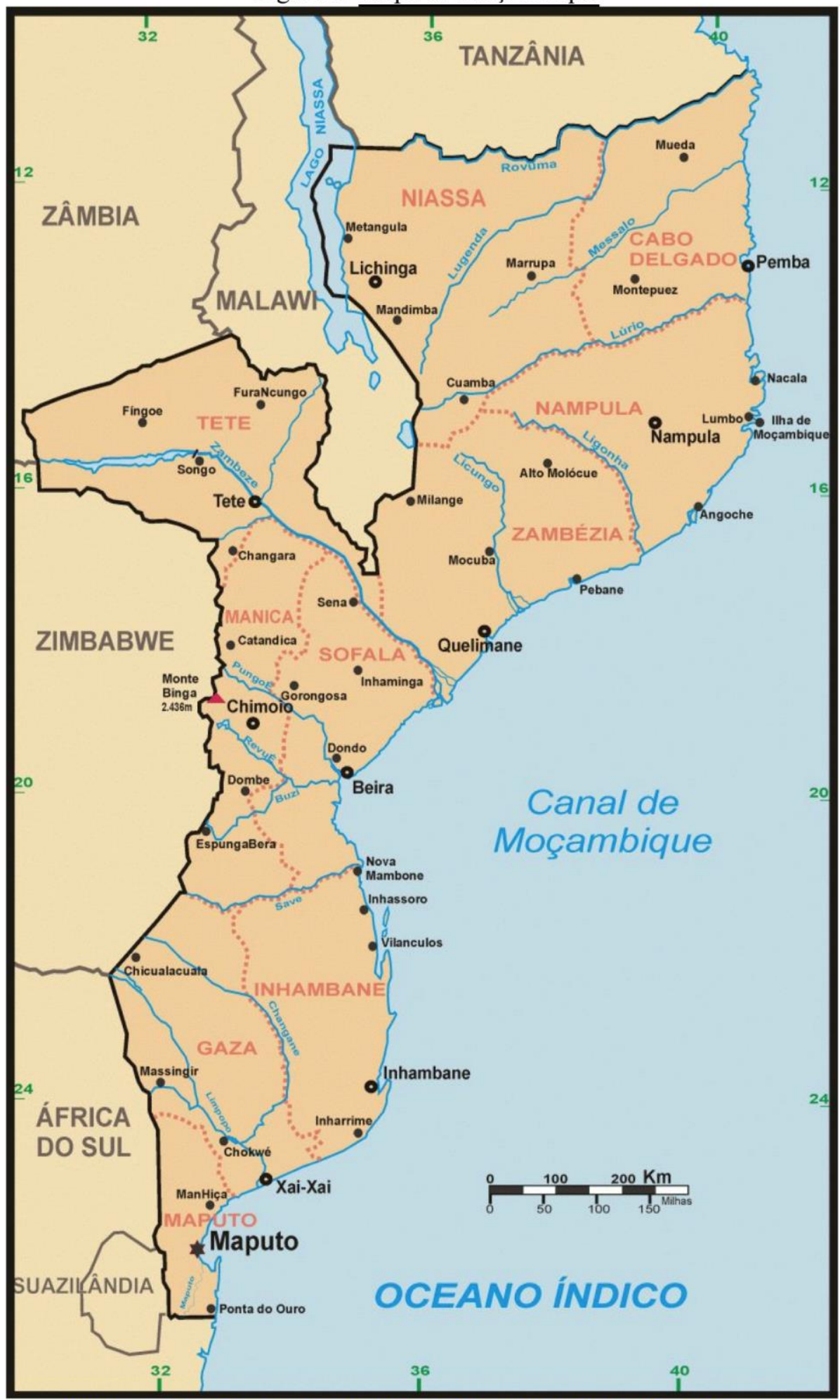

Fonte: http://www.portaldogoverno.gov.mz/Mozambique/mapa_mocambique.jpg 
Moçambique - país que se localiza na costa oriental da África, com uma superfície total de aproximadamente $800.000 \mathrm{~km}^{2}$ e um litoral com pouco mais de 2500 km de costa. O país faz fronteira, ao norte, com a Tanzânia, ao sul, com a África do Sul e a Suazilândia, ao oeste, com o Zimbabwe, Zâmbia e Malawi e, ao leste, com o vasto Oceano Índico. Geograficamente, distinguem-se três grandes regiões (Norte, Centro e Sul) com características distintas, tanto sob o ponto de vista cultural, como em relação às suas potencialidades naturais e em termos de recursos.

As três regiões geográficas perfazem 11 províncias administrativas, sendo a região Norte constituída por Cabo-Delgado (o berço do grupo étnico dos Macondes), Niassa (característica pelos seus ritos) e Nampula (o berço da cultura Macua e destaque para as grandes linhagens matrilineares). Na região Centro encontram-se as províncias de Tete, Zambêzia, Manica e Sofala, destacando-se nelas as etnias Nguni, Cena, Ndau. Por fim, a região Sul, onde se localizam as províncias de Inhambane, Gaza, Maputo (província) e Maputo (cidade), onde predomina a cultura Tsonga e os seus rituais do lobolo.

Moçambique, à semelhança de muitos países africanos, apresenta uma diversidade de culturas e tradições, hábitos e costumes que constituem sua maior riqueza e norteiam a vida das populações locais por diversas gerações. A historicidade de Moçambique não pode ser dissociada do processo de colonização europeia que durou cerca de 500 anos. Porém, já antes da penetração colonial, as populações locais que viviam da caça e recolecção tiveram ligações, primeiramente com povos Bantu, emigrantes oriundos da região central da África, e da fusão surgiram as primeiras sociedades sedentárias com domínio da agricultura e do processo de fabrico do ferro. Por volta do século IX começam as primeiras ligações comerciais com povos asiáticos através do Oceano Índico. Destas ligações, surgiram casamentos e a introdução do Islã entre as comunidades locais e os árabes que influenciaram as formas de vida, os hábitos, usos e costumes. Nestas sociedades, organizadas por linhagens, a terra era patrimônio e não propriedade das linhagens e podia ser usada de livre vontade, cabendo ao chefe da linhagem a sua distribuição pelas famílias.

A invasão portuguesa, que teve seu início em 1498 e término em 1975 trouxe, entre diversos acontecimentos, a destruição dos modos de vida da população nativa por meio da posse de terra e da escravização das populações locais. Em última análise, qualquer que tenha sido a forma de atuação, a invasão portuguesa veio, de certa forma, criar uma nova organização dos espaços rurais moçambicanos. 
Para a implantação do regime colonial em Moçambique, as companhias majestáticas e o sistema dos prazos foram as formas mais significativas que o sistema colonial português encontrou para a colonização das regiões Centro e Norte. Os prazos referiam-se a concessões de terras que eram definidas por duas ou três gerações e transmitidas por via feminina (mais especificamente a filha mais velha). A forma de utilização da terra foi por via de monoculturas direcionadas ao mercado exportador, obrigando a população nativa a se integrar no trabalho assalariado, que constituía a mão-de-obra barata nessas plantações. Esses prazos estabeleceram linhagens bastante poderosas, e não se pode deixar de mencionar a influência asiática em Moçambique, gerada pela grande maioria dos prazeiros ${ }^{1}$ oriundos da Ásia. Ademais, o já existente comércio marítimo entre os povos asiáticos e os povos do litoral de Moçambique trouxe também a expansão de povos muçulmanos para o país, que se concentraram, na sua grande maioria, no Norte de Moçambique.

A colonização do Sul do país estava sob o domínio total da colônia portuguesa. A estratégia utilizada aqui foi atrair os moçambicanos ao trabalho migratório, com destaque para as minas de ouro da África do Sul, transformando a região numa reserva de mão de obra para o trabalho de exploração mineira. O Sul era ainda o grande centro de arrecadação de impostos e benefícios para a economia portuguesa, mediante utilização dos caminhos de ferro, portos e estradas que ligavam Lourenço Marques (Maputo) ao hinterland, bem como a ligação do porto de Lourenço Marques à África do Sul.

Na medida em que se consolidava o colonialismo português em Moçambique, a produção de monoculturas foi institucionalizada e agravada, introduzindo-se culturas forçadas, bem como o trabalho forçado, tanto para servir a indústria extrativa mineira sul-africana como para as atividades nas plantações de monoculturas. Portanto, assistese em Moçambique à entrada acentuada do investimento estrangeiro, especialmente na indústria manufatureira e a integração da economia num contexto de economia regional de domínio sul-africano.

Não à toa que, com a conquista da independência nacional, houve uma total preocupação em se reverter a condição da posse da terra em favor dos moçambicanos

\footnotetext{
${ }^{1}$ Os prazeiros eram representados por colonos portugueses ou "indo-portugueses" (indianos convertidos ao catolicismo, que adotaram nomes portugueses e pretendiam fixar-se em Moçambique), comerciantes e soldados que, muitas vezes, se casavam com as filhas dos chefes locais, estabelecendo linhagens bastante poderosas (UEM, 1983).
} 
que nela viviam e trabalhavam. Nesse contexto, a terra se torna pública e, consequentemente, o grande legado pelo qual nós, moçambicanos, temos orgulho. Afinal, desde a independência nacional que estão assegurados o acesso, posse e controle da terra pelas famílias moçambicanas. No decurso destes últimos 40 anos de Moçambique independente, transformações estruturais foram observadas nos sistemas econômicos e sociais do país, dada a dinâmica da própria economia mundial que, dominada pelos interesses do modo de produção capitalista, fizeram com que os governos, nos diferentes momentos históricos, realizassem mudanças de governação e adoção de políticas que se enquadrassem nos intentos dessa onda sedente de acumulação capitalista. Entretanto, a questão fundiária continua preservada em favor do Estado, único proprietário da terra em Moçambique e, consequentemente, em benefício do povo moçambicano.

Afinal, Moçambique transitou de um regime colonial, como colônia portuguesa, para uma economia completamente influenciada pelos ideais socialistas, um regime de economia de mercado. No período do sistema de economia centralizada, foram implementadas políticas de socialização das forças produtivas, com destaque para os espaços rurais onde se concentrava a grande maioria da população. A estratégia de desenvolvimento visava à modificação do espaço rural, com a promoção da produtividade, a nacionalização das grandes monoculturas e plantações (bem como as fábricas de processamento), a criação de cooperativas agrícolas aliadas ao movimento das aldeias comunais e a institucionalização de um sistema econômico de planificação centralizada.

$\mathrm{Na}$ realidade, referem alguns pesquisadores, tal como Mosca (2005), que essas medidas visavam à construção de uma sociedade socialista, em que a estratégia de desenvolvimento rural se assentava na socialização do campo, onde, por um lado, o modelo produtivo seria baseado nas empresas estatais com critérios específicos de superfície agrícola, volume e destino da produção, número de trabalhadores, entre outros. Essas empresas funcionavam ainda como instrumentos de poder, de soberania e de transformação econômica. Por outro lado, existiriam as cooperativas agrícolas, que deveriam eliminar o individualismo, a dispersão e as dificuldades de controle da população funcionando como uma via para envolver os camponeses na coletivização produtiva e funcional (MOSCA, 2005; CASAL, 2008; JAKOBSEN E CARVALHO, 2008). Assim, de acordo com os autores citados, constituíam focos de mudança os seguintes: 
$\checkmark$ as aldeias comunais, que buscavam integrar o setor produtivo rural com a indústria. A intenção era promover o aumento da produção agrícola, ao mesmo tempo em que melhorava as condições de $80 \%$ da população de Moçambique que, nesse momento, se localizava no campo;

$\checkmark$ as empresas estatais, no lugar das unidades de produção que tinham como critérios a dimensão e a contiguidade da superfície agrícola, volume e importância da produção (produtos de exportação ou para a alimentação das cidades), número de trabalhadores, volume de recursos necessários para o funcionamento (financiamento corrente, investimento, infraestrutura, etc.);

$\checkmark$ as cooperativas agrícolas, concebidas como forma de eliminar o "individualismo", a dispersão e as dificuldades de controle da população e, numa perspectiva positiva, facilitar as funções de prestação dos serviços essenciais (educação, saúde, água, melhoria de habitação etc.).

O objetivo aqui era sair da dependência econômica na qual Moçambique estava mergulhada com as políticas econômicas coloniais. No entanto, diversas incongruências na aplicabilidade das políticas e a ineficiência destas diante dos objetivos almejados levaram o governo a abandonar os ideais socialistas. Para além do cenário apresentado, a guerra civil em Moçambique, que teve início em 1977, dois anos após a proclamação da independência nacional em 25 de junho de 1975, veio a contribuir grandemente para a dificuldade na aplicabilidade das políticas. As consequências trazidas pela guerra foram extremamente negativas sob o ponto de vista de o país focar seus planos de políticas transformistas no campo, região onde o que mais se observava era o abandono pela população e a massiva destruição das infraestruturas, campos de produção, redes de comercialização, etc., ou seja, abandono e destruição do fraco sistema que havia garantido maior parte de produção e circulação do consumo interno, com ações geradas pelos bandidos armados que viam essa atuação como a forma de destruir e desestabilizar o pais.

Por sua vez, a subordinação às economias do centro e a vulnerabilidade pela qual a economia do país atravessava, à semelhança de vários países subdesenvolvidos nos anos 1980, também contribuíram para que o governo de Moçambique, àquela altura, aceitasse a ajuda internacional, que vinha com a condição primária de mudança para um sistema econômico liberal. Passamos, assim, aos cânones da economia de mercado, iniciando um novo ciclo de desenvolvimento da economia de Moçambique, com um 
programa de ajustamento estrutural com o Banco Mundial (BM) e o Fundo Monetário Internacional (FMI), inicialmente designado Programa de Reabilitação Econômica (PRE) de 1980 a 1990, combinando, mais tarde, ao componente social, o que mudou a designação para Programa de Reabilitação Econômica e Social (PRES). De modo geral, esses programas tinham por objetivo a redução global do controle administrativo da economia, a fim de reestabelecer incentivos comerciais para promover a produção e o comércio, sendo que estavam assentes nas privatizações, característica marcante do período. Os programas vinham com o discurso de envolvimento em peso do setor familiar na economia, dado que este setor, especialmente na agricultura, até então era o elemento chave de desenvolvimento econômico a ser dominado pelo setor familiar de produção.

Portanto, o impacto das políticas no âmbito do ajustamento estrutural e suas consequências também se fizeram sentir sobremaneira no meio rural, levando as famílias a procurarem formas de absorver os benefícios prometidos. Assim, famílias rurais recriam novas formas de trabalho e ajustam seus recursos materiais e humanos, ou seja, reorganizam suas famílias e comunidades para estarem capacitados a responder aos intentos do capital e dele se beneficiarem.

No contexto da terra, a propriedade continua pertencente ao Estado reforçada pela criação da Lei de Terras de 1990, que regula a propriedade e as condições de uso e aproveitamento da terra. No entanto, destaca-se na Lei de Terras as normas ligadas ao direito consuetudinário e tradicional, privilegiando, dessa forma, as comunidades e sua ação na utilização e na preservação da terra. Vários debates já foram desenvolvidos a fim de tornar a terra num bem privado. Os debates defendem uma total incoerência de decisões políticas ao manter a terra como elemento nas mãos do Estado, ao mesmo tempo em que, dentro do contexto de economia capitalista, existe a preocupação de se atrair investimento externo privado que preze pela propriedade privada dos meios de produção, incluindo a terra. Afinal, atraindo para o país uma fonte incalculável de investimento externo para a agricultura, perspectivando o desenvolvimento intensivo desta para alimentar o mercado exportador, a propriedade privada se mostra mais coerente e segura no investimento. Entretanto, há que se realçar, que a propriedade pública da terra nunca foi ponto imperativo para as decisões de investimento privado, mesmo na agricultura, pois várias empresas herdadas do sistema colonial continuam operando em caráter privado em Moçambique. Recentemente, cada vez mais projetos 
de investimentos estrangeiro estão direcionados para a agricultura como a força motriz para alavancar a economia.

Se para o investimento privado existem reticências quanto à utilização da terra e seu caráter público de posse, para as comunidades e famílias rurais, os direitos sobre a terra, no que diz respeito ao acesso, posse e controle, configuram-se como um problema resolvido, depois que ficaram definidos os contextos e limites da atuação das comunidades locais na Lei de Terras. A Lei de Terras reconhece e respeita o direito das comunidades locais como detentoras tradicionais da terra, sendo essas reguladas por culturas e tradições referentes a cada comunidade e suas etnias. Entretanto, não se pode dizer que no nível familiar existe a mesma percepção e direitos iguais quando se trata de mulheres e homens, ainda que, pela lei, não exista distinção de gênero para tal. Talvez a combinação entre as leis formais e costumeiras explique o porquê e/ou onde se inicia tal tratamento diferencial nas questões da terra.

$\mathrm{Na}$ verdade, o campo de acesso à terra nas regiões rurais vai muito além daquilo que é mostrado pelas leis. Uma vez que a terra é o ativo principal na geração de condições que proporcionem o preenchimento adequado das necessidades básicas da maioria da população moçambicana, a forma como ela é cedida, controlada e herdada constitui uma das bases mais importantes de socialização que influencia as escolhas dos diferentes grupos sociais (NEGRÃO, 2000). Estudar esse complexo mecanismo de acesso, posse e controle da terra no seio das comunidades rurais torna-se fascinante na medida em que constitui a melhor via de incursão nas tradições, que podem ajudar a compreender a forma como estas moldam e são moldadas pelas construções sociais que determinam o lugar e a função dos gêneros na sociedade moçambicana.

Se o que a história mostra é a incursão e a adaptação do país ao dominante modo de produção capitalista, com todas as suas contradições, então, vale lembrar que, em Moçambique, o padrão de acumulação se encontra concentrado nas regiões rurais, sendo o setor agrícola a principal fonte de subsistência do país. Indiscutivelmente, também é sabido que a contribuição das mulheres nas atividades produtivas de acumulação de capital garantem a sustentabilidade da economia rural, bem como a segurança alimentar e a acumulação de riquezas em nível familiar, tudo isso porque as formas de organização familiar se orientam pelas tradições e culturas, que impactam nos papéis dos homens e das mulheres em seus contextos familiares, sendo conferido às mulheres o papel social de produtoras e guardiãs da vida social no campo. 
Dentro dessa lógica, o objetivo principal da tese é discutir a questão da terra, focando os problemas que as mulheres enfrentam para o acesso, posse e controle da terra junto às comunidades tradicionais onde estão inseridas. Procura-se perceber de que forma as mulheres tem o acesso à terra e se a posse e o controle das mesmas lhes são conferidos. No contexto das suas tradições e culturas, pretende-se perceber como a mulher se posiciona e que estratégias busca para fazer valer seus direitos, expressos na Lei formal.

Portanto, toma-se aqui a mulher como elemento central de discussão, estando esta inserida nesse contexto de culturas e tradições historicamente adquiridas e que a identificam como pertencente ao grupo. No entanto, a análise se concentra no argumento de que, quaisquer que sejam os constrangimentos que as mulheres enfrentem para exercerem o controle da sua vida e terem acesso aos recursos fundamentais para a sua sobrevivência, existem formas de contornar, sem no entanto confrontar e questionar os preceitos das tradições e culturas, de modo que garantam e mantenham para elas o acesso, a posse e o controle da terra e outros bens, em caso de necessidade.

Esta temática é resultado, em primeiro lugar, das inquietações que ficaram por ser respondidas durante as pesquisas feitas no âmbito da elaboração do meu trabalho de mestrado, focado nos pequenos produtores de caju do distrito de Manjacaze, ao Sul de Moçambique. Durante as pesquisas, pude constatar que:

(i) as categorias acesso, posse e controle eram distintas e podiam não caminhar juntas. Por "acesso", entende-se a capacidade de as mulheres terem a terra para o uso como elemento fundamental de reprodução social. À "posse", refere-se a forma legal de utilização dela, pela importância que toma como fator de produção, agente social, fonte de rendimento e o lugar físico onde fluem as tradições e culturas que expressam a identidade dos povos. $\mathrm{O}$ controle é a capacidade que define as formas de uso, de decisões sobre o que fazer com o recurso terra;

(ii) a condição de ser mulher ou de ser homem dentro de um grupo familiar funciona como determinante para se ter, efetivamente, o acesso, posse e controle sobre a terra e/ou qualquer outro recurso ou bem material de caráter duradouro, à semelhança de um imóvel construído num espaço familiar;

(iii) por menor que seja a exploração agrícola da família, a esperança de se beneficiar o máximo possível do que o mercado disponibiliza se mostra 
presente. Num contexto em que a mulher, especialmente do Sul da região estudada, é a principal força de trabalho agrícola (pois é característico da região os homens migrarem), as complicações que ela enfrenta impactam, não apenas na produção em si, mas, sobretudo, na sua motivação no trabalho agrícola, bem como nos cuidados com a terra para os subsequentes ciclos de produção, comprometendo o próprio desejo de se inserir nessa onda de produção direcionada ao mercado.

Em segundo lugar, essa temática é resultado da percepção que tenho de que existem, e cada vez mais acentuadas, assimetrias de informação entre homens e mulheres, especialmente nos espaços rurais que culminam em uma maior subordinação das mulheres com relação aos homens. Essa constatação retiro da convivência frequente que tenho com diversas mulheres de algumas comunidades rurais, especialmente de alguns povoados de Inharrime, distrito da província de Inhambane ao Sul do país, local de onde vem o homem com quem me casei. As ligações que o meu marido mantém com seu local de origem são tão fortes que, em 10 anos de casada, tirando os que permaneci aqui no Brasil, deslocávamo-nos quinzenalmente ao distrito de Inharrime, daí a interação que pude desenvolver com diversas mulheres entre membros da família e outras pertencentes a famílias vizinhas. De certa forma, essa convivência despertou em mim o interesse de perceber melhor a comunidade em que está inserida a família com quem me juntei por casamento, seus mecanismos de acesso, posse e controle da terra. 


\section{Procedimentos Metodológicos}

Em 2009, ingressei no Programa de Pós-Graduação em Agronegócios na Universidade de Brasília (PROPAGA/UnB) e me propus a trabalhar com os pequenos produtores familiares de caju do distrito de Manjacaze, na província de Gaza, em Moçambique. Realizei um trabalho exaustivo e prazeroso de pesquisa de campo na companhia do meu marido que, aliás, é bastante presente no meu dia a dia acadêmico. Visitei cada família juntamente com ele, que me ajudou muito na interpretação das questões colocadas ou na tradução das respostas dadas pelos entrevistados, afinal, as entrevistas decorriam na língua chichope que muito pouco domino.

Durante as entrevistas, por várias vezes, tive de abandonar o roteiro que levava religiosamente comigo, pois, os dados que as famílias me apresentavam iam muito além daquilo que eu pretendia saber. À semelhança de uma visita familiar, sentávamo-nos à sombra de uma árvore qualquer e, de nossas "conversas", pude obter as mais ricas informações. Pois bem, o que colhi dessas "conversas" foi muito precioso, tanto para a realização do meu trabalho de mestrado como, e fundamentalmente, para me inteirar da cultura chope, de suas relações sociais no quadrante relações interfamiliares e com os bens familiares dos quais a terra faz parte. Até então, para mim, as leis formais que regulam os diversos mecanismos da vida social e econômica existentes em Moçambique eram o que bastava para me posicionar em relação a qualquer situação da vida. As famílias me mostraram que, antes de recorrer às leis formais, seria interessante saber o que diz a sociedade onde encontram-se inseridas, quais os limites que a família com quem se vive apresenta, o que para elas é de suma importância, podendo ou não sair do seu domínio.

Com algumas informações fiquei confusa, afinal, vivemos em um país onde a terra é pertencente ao Estado. Ouvimos falar, desde os tempos de Samora $\mathrm{Machel}^{2}$, que a terra pertence ao povo e é de quem nela trabalha. Em Manjacaze, por todas famílias por onde passei, quem trabalhava na terra e quem cuidava da casa era a mulher, ou seja, a mulher é o suporte da família e guardiã da terra e de todas as benfeitorias nela contidas. Por outro lado, o homem, seu marido, pai, irmão ou filho migrava em busca de trabalho assalariado nas grandes cidades ou, como foi o caso da maioria, nas minas

\footnotetext{
${ }^{2}$ Primeiro presidente de Moçambique independente.
} 
da “Joni ${ }^{3 "}$ ", como é conhecida a designação da vizinha África do Sul. Ainda que isso fosse uma verdade incontestável, as mulheres não tinham nenhum direito nem por essa terra, nem pelos bens duradouros e, muitas vezes, davam seu suor na busca de água para construir a moradia da família. Os filhos também não lhe pertenciam; criou-os "sozinha" com o suor de seu trabalho na terra e, por vezes, nem o seu próprio destino a pertencia, afinal, em caso de viuvez, alguém da família do marido convocaria uma reunião para decidir qual seria o seu destino a partir daí.

Portanto, diante daquilo que era automático de se pensar e agir na minha cabeça, a realidade do campo me mostrou uma postura contrária, e me perguntei: afinal, qual é mesmo o papel destas mulheres? O que lhes cabe na vida quando crianças, jovens e depois mulheres adultas em seus lares? Qual é o sentido e valor que elas dão à vida, à terra e ao trabalho nela efetuado, se de antemão sabem que seus destinos são incertos no contexto familiar? Ao mesmo tempo em que me questionava, apercebia-me que a minha realidade não estava tão longe daquilo que via e ouvia. Aquelas famílias de Manjacaze com quem trabalhei eram machopes e eu estava ali do lado de um, meu marido. Bom, o que me levara a Manjacaze não era questionar as tradições, as culturas, os hábitos ou costumes, mas sim, colher dados para meu trabalho de mestrado e, assim, continuei firme e forte.

Finalizei o meu trabalho e, na banca de defesa, um dos examinadores mostrou interesse nas questões da terra em Moçambique e da forma como ela foi explorada no trabalho. Esse fato, aliado às inquietações que se mantiveram em mim durante as pesquisas de campo, me fez ficar atenta e observar mais e procurar entender como é esse universo das relações sociais entre os chopes, a comunidade da qual, hoje, faço parte em Inharrime, e me levou a pensar que um doutorado teria sentido se eu pudesse estudar e explorar mais essa questão focando especialmente a mulher. Foi nesse contexto que propus-me a estudar o acesso, posse e controle da terra pelas mulheres rurais do distrito de Inharrime.

\footnotetext{
${ }^{3}$ Expressão popularmente usada para se referir à vizinha África do Sul. Deriva do nome de uma das cidades sul-africanas mais populares, a cidade de Johanesburgo.
} 


\section{Local de Estudo}

A divisão de Moçambique inclui províncias, distritos, postos administrativos e localidades, além de existirem regiões urbanas com as cidades e as vilas. Hoje, com o processo de descentralização em curso no país, foram criados os municípios. O estudo decorreu no distrito de Inharrime, localizado ao Sul da província de Inhambane.

O distrito faz fronteira ao Norte com Panda, Homoíne e Jangamo. Ao Sul, encontram-se o distrito de Zavala e parte da província de Gaza (Mandlakaze). Ao Oeste, está o distrito de Panda e, ao Leste, o Oceano Índico. O distrito ocupa uma superfície territorial de $2.748 \mathrm{~km}^{2}$ do total de $68.775 \mathrm{~km}^{2}$ da província de Inhambane. A figura 2 apresente o Mapa do distrito:

Figura 2. Mapa do distrito de Inharrime

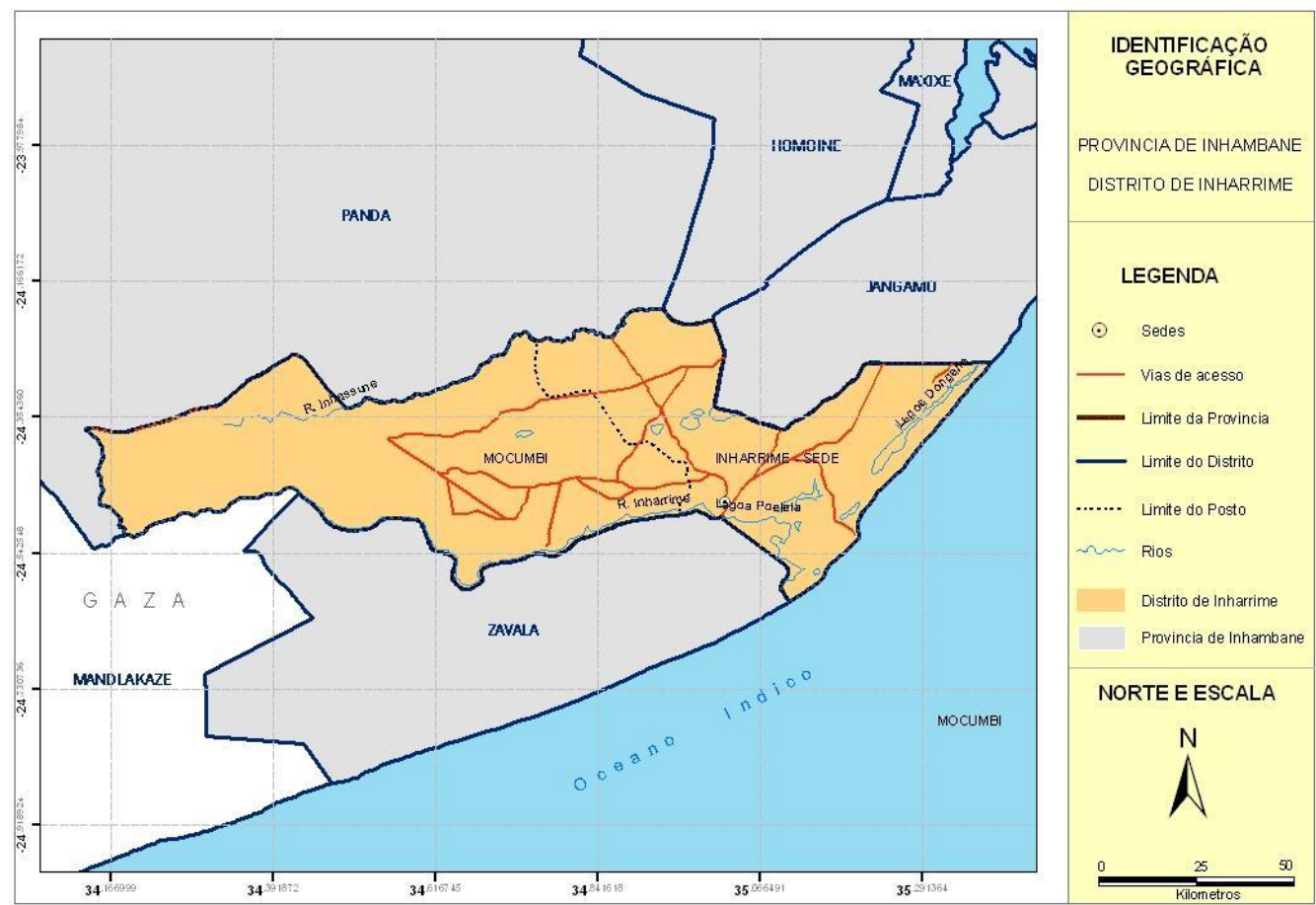

Fonte: Moçambique (2012a)

O distrito tem uma população estimada em 116.285 habitantes, dos quais 64.358 são mulheres, sendo de matriz rural devido à taxa de urbanização de 5\% 
(MOÇAMBIQUE, 2005; MOÇAMBIQUE, 2012a). As explorações estão divididas em cerca de 48 mil parcelas, metade com menos de meio hectare e exploradas em $60 \%$ dos casos por mulheres (MOÇAMBIQUE, 2005). A distribuição das mulheres ativas por setor de atividade é a seguinte: $98 \%$ trabalham na agricultura e os $2 \%$ restantes se dividem entre o setor comercial formal e informal e o setor da saúde e educação (MOÇAMBIQUE, 2005).

No geral, o distrito Inharrime é caracterizado por assentamentos dispersos, em que o tipo de habitação, na grande maioria, é a palhota, com pavimento de terra batida, cobertura de capim ou colmo e paredes de caniço ou paus. Muito pouco se observa casas de madeira, e apenas se observa $10 \%$ do total das habitações de bloco de cimento, em que, na sua maioria, estão localizadas na sede da vila (MOÇAMBIQUE, 2005; MOÇAMBIQUE, 2012a). Bens considerados duráveis em nível das comunidades comuns, apresentados pelas famílias, são rádio, telefone e bicicleta. Nas comunidades estudadas, nenhuma possuía energia elétrica, apenas uma apresentou um gerador. $\mathrm{O}$ comum era uma placa solar ou bateria, apenas para carregar as baterias dos telefones, sendo comum a energia proveniente do petróleo/parafina/querosene e lenha.

Dados sobre a história do distrito dizem que a administração colonial foi criada em 1816, funcionando apenas como circunscrição, pois, apenas funcionavam no distrito quatro. Apenas nos anos 20, com a redistribuição das terras, Inharrime se torna administração do conselho, depois que conseguiu os seis regulados necessários para ascender à categoria de administração. O primeiro régulo de Inharrime (régulo Nhanombe) surge nomeado pelos portugueses em reconhecimento à coragem deste ao enfrentar Ngungunhane, impedindo que este atravessasse o território (MOÇAMBIQUE, 2012b). Atualmente, o distrito é composto por três postos administrativos: Sede - localidade de Nhanombe, Mucumbine e Chacane. A localidade Nhanombe, também considerada regulada pelas leis costumeiras, ocupa a grande maioria do distrito, onde se localizam as estruturas formais de governação. Foi na localidade de Nhanome onde me concentrei na realização das pesquisas de campo. A localidade de Nhanombe ${ }^{4}$ possui os povoados de Macupulane, Nhamiba, Jelengue, Ngulela, Nhamadjasso, Nhancongo, Xidigua, Nhantumbo, Ussaka, Mbiene e Dongane. Devido à dimensão da localidade, o estudo concentrou-se no povoado de Macupulane,

\footnotetext{
${ }^{4}$ Esses dados foram obtidos por informação oral no decorrer da entrevista com o secretário do bairro do distrito de Inharrime no dia 10/01/15. Os nomes podem ter outra designação gráfica, devido a dificuldades encontradas para a verificação da grafia correta.
} 
especialmente nas unidades um e dois de Banzala. O povoado possui ainda outras quatro unidades, respectivamente: Nhatungue, Mazivila, Incumbine e Impindo.

A população de Inharrime se considera chope e tem a língua chichope como sua língua materna. Na verdade, na grande maioria das famílias, a língua portuguesa é aprendida no processo de alfabetização nos primeiros anos escolares. Aliás, a taxa de analfabetismo é um dado preocupante para o distrito de um modo geral e para a população feminina em particular. $\mathrm{O}$ analfabetismo de mulheres acima dos 40 anos encontra-se acima dos $60 \%$ e o dos homens estão bem abaixo dos $25 \%$, conforme mostram os dados estatísticos em Moçambique (2012a).

A organização tradicional no distrito é notória e respeitada. As lideranças tradicionais recebem designação própria, correspondente ao idioma praticado, sendo: Nhandibande - o homem da terra; wa hombe - figura de autoridade e Madodas - os mais velhos (os anciãos). Portanto, compõem as figuras de autoridade, os que dominam os contextos políticos e sociais, os Nhandibande, Wa hombe e os Madodas.

A atividade econômica do distrito é basicamente dominada pela agricultura, sendo esta praticada pelo setor familiar disperso. No geral, a produção é para subsistência, com quase nenhum uso de tecnologias modernas de produção. Entretanto, existem algumas explorações agrícolas privadas com o uso de sistemas modernos de irrigação. Explorando áreas relativamente maiores que se dedicam, para além das culturas alimentares, a produção de culturas de rendimento tem especial destaque para o ananás e citrinos. A pecuária e a mineração também são setores relativamente importantes para a economia do distrito. Existe em Inharrime uma grande produção de galinhas e do gado bovino. Entre os minérios, destaca-se a argila, titano e o xisto (MOÇAMBIQUE, 2012a; MOÇAMBIQUE, 2012b).

\section{Etapas da Pesquisa}

Antes de iniciar com a descrição das etapas que corresponderam a pesquisa de campo que deu origem a esta tese, importa esclarecer alguns pontos de interesse. $\mathrm{O}$ projeto apresentado ao programa para o exame de qualificação, ocorrido em março de 2014, levava uma proposta de análise do tema na perspectiva do gênero aliado a 
questões agrárias, pois o estudo seria feito com o olhar direcionado a mulher rural, sendo esta a atuante principal da agricultura.

Diversas foram as leituras feitas no sentido de se perceber como eram tratadas as questões de gênero em Moçambique e como a academia moçambicana acompanhava a dinâmica internacional no desenvolvimento teórico e prático da questão. Fato interessante foi perceber que as questões de gênero, ainda que em última instância caminhem para o mesmo objetivo, as lutas e a militância deveriam ser distintas das apresentadas, especialmente pelo ocidente, pelo fato de a emancipação da mulher moçambicana ter sido assunto de pauta ainda no decorrer do processo de revolução que culminou com a independência nacional:

A libertação da mulher é uma necessidade fundamental da Revolução, uma garantia de sua continuidade, uma condição de seu triunfo. A Revolução tem por objetivo essencial a destruição do sistema de exploração, a construção de uma nova sociedade libertadora das potencialidades do ser humano e que o reconcilia com o trabalho, com a natureza. É dentro deste contexto que surge a questão da emancipação da mulher. Não se pode liquidar só uma parte da opressão [...] Como fazer então a Revolução sem mobilizar a mulher? Se mais da metade do povo explorado e oprimido é constituído por mulheres, como deixá-las à margem da luta? A Revolução para ser feita necessita mobilizar todos os explorados e oprimidos, por consequência, as mulheres também (MACHEL, 1979, p. 18).

Como pode se observar com a citação, a revolução devia ocorrer em paralelo com a emancipação da mulher, ficando consagrada na constituição a igualdade de direitos para homens e mulheres. Na sequência, as políticas e programas desenvolvidos passaram a contar com o elemento facilitador para a eliminação, ainda que gradualmente, dos fatores que restringem o acesso e controle dos recursos e o acesso aos órgãos de tomada de decisão pelas mulheres. Assim, pretendia-se chegar em última análise na percepção do processo de empoderamento da mulher por vias de acesso à terra e incremento da produção agrícola, entendendo-se que o impedimento para que tal ocorresse era as relações sociais em que ela estava envolvida.

Pois bem, em primeiro lugar, exaustivas discussões ocorreram com o meu orientador, que incansavelmente procurava fazer-me perceber que o empoderamento não cabe como questão, tampouco como o fim. Na verdade, concordamos que seria mais interessante pensar sob o ponto de vista da autonomia da mulher, tanto que, por diversas vezes, deixou claro que o termo empoderamento não lhe trazia simpatia para o tema em questão. 
Em segundo lugar, feita a defesa do projeto, as discussões me conduziram a certificar que gênero e questões agrárias não eram temas que ajudariam a explicar os meandros da problemática da terra em Moçambique. Por um lado, Moçambique está envolvido no contexto da economia capitalista internacional, atuando como periferia em relação ao centro e fonte de acumulação para as grandes economias. Ainda assim, o país mantém a propriedade pública da terra, o que contraria as leis da economia capitalista. Por outro lado, o caráter tradicional das formas de organização das sociedades/comunidades ou famílias toma a terra mais como um elemento central de existência humana e menos como um recurso produtivo. A terra representa a essência do ser, a casa, o sagrado, o divino. Este fato, que é característico em muitos povos africanos, especialmente em países do sul da África, fez com que os governos tivessem que ajustar suas leis formais, no sentido de estas seguirem em paralelo com as leis tradicionais de vivência humana, pois percebe-se que a comunidade e os poderes tradicionais devem participar ativamente no processo de desenvolvimento do país, fato que originou uma dualidade de sistemas jurídicos.

Disso resultou, em discussões com a banca examinadora, a percepção de que existiriam diversas complexidades no tema, que não seriam inteiramente explicadas mediante o referencial teórico apresentado. Na verdade, concordou-se que o olhar teórico do ocidente não descortina as questões culturais enraizadas nas comunidades rurais africanas e não explica as tensões do acesso, posse e controle da terra em Moçambique. Por esse fato, sentimos necessário mudar o referencial teórico, absorver o máximo possível de dados da pesquisa de campo, bem como privilegiar a experiência empírica que tenho sobre o tema, sobre a região, culturas e tradições.

Diversos estudos que se debruçam nas questões culturais africanas (continente em que a grande maioria da população é negra) são escritos na perspectiva do ocidente, por brancos que tampouco vivem, na primeira pessoa, o regime cultural e tradicional africano. Assim, poucos são os estudos feitos por pessoas negras, pertencentes à comunidade em questão, em que, de certa forma, ou na totalidade, são afligidas pelas tradições locais. Portanto, o diferencial deste trabalho seria o fato de ser escrita por uma moçambicana, negra, que estaria falando na primeira pessoa sobre a problemática apresentada na pesquisa.

Feitas as reformulações, são, então, descritas as etapas do trabalho de pesquisa que deu resultado a esta tese, ainda que não de forma linear, como serão aqui apresentadas. A primeira etapa correspondeu a uma pesquisa bibliográfica, que ocorreu 
de março de 2012 a janeiro de 2016. A distância com a realidade trabalhada gerou dificuldades no acesso a materiais físicos, científicos e acadêmicos sobre o tema. Numa fase inicial, o suporte foi a internet e a biblioteca virtual, que ainda assim apresentavam limitações de busca a trabalhos acadêmicos escritos e publicados em fóruns científicos de Moçambique. As deslocações ao país possibilitaram a realização de consultas em bibliotecas como a da Universidade Eduardo Mondlane (UEM), a do Centro de Estudos Africanos (CEA), a do arquivo histórico de Moçambique e a do Instituto de Estudos Sociais e Econômicos (IESE). Foi possível também estabelecer contatos com alguns pesquisadores que facultavam o acesso físico a trabalhos e livros publicados.

Existe um exaustivo debate, tanto acadêmico como político sobre a questão da dependência externa em que Moçambique encontra-se mergulhado, onde se discutem seus impactos para a economia bem como para a sociedade, especialmente a rural, onde reside a maioria da população de Moçambique. O suporte teórico da dependência externa foi baseado em Ruy Mauro Marini (2000, 2012), que discute a questão da dependência externa da América Latina, especialmente no Brasil. Além de ser um clássico, é de suma importância para a discussão da questão, pois a participação de Moçambique nos organismos internacionais de regulação econômica geralmente é feita em blocos e, em alguns deles, como na Organização Mundial do Comércio (OMC), as pautas de discussão estão aliadas ao Brasil. Os debates críticos sobre a questão da dependência externa são ricamente apresentados por pesquisadores do IESE, como Orlando Nipassa (2009) e Carlos Nuno Castel-Branco (2011). Recorreu-se ainda a autores como Hector Guerra Hernandéz (2009), Maria Paula Meneses (2010) e José Luís Cabaço (2007), que mostram os caminhos da dependência nos diferentes momentos históricos pelos quais o país passou.

Nas questões de prisma tradicional e cultural, em tratando-se de espelhar o interior das famílias, não podia passar despercebido do clássico de Friedrich Engels (1987), “A origem da família, da propriedade privada e do Estado”, e do recurso Jimi Adesina (2012), que discute a necessidade de nos dissociarmos da dependência a trabalhos epistemológicos universais definidos pela Europa nas discussões das relações de gênero. $\mathrm{O}$ argumento é que já existem trabalhos africanos de valor epistemológico nas ciências sociais que podem muito bem interagir com trabalhos acadêmicos. Henri Junod (1996) descortina aspectos culturais da tribo Tsonga e a escritora moçambicana Paulina Chiziane, primeira mulher negra moçambicana, de origem chope, a escrever 
um romance, aborda em seus livros aspectos sociais da cultura do sul do país, especialmente ricos em estórias sobre mulheres e suas tradições.

No campo do acesso, posse e controle da terra, foi mais difícil encontrar material que trate das questões da terra num contexto fora da mediação desta com a agricultura, pois o olhar que dá-se à terra neste trabalho é a relação que se estabelece nos domínios sociais que vão qualificar a mulher. O trabalho de Heidi Gengenbach (1998) foi especialmente importante para percepção do enquadramento da mulher na família e das relações que estas estabelecem com a terra. Clarifica os rituais pelos quais a mulher deve passar que, consequentemente, garantem-lhe o acesso à terra. Neste trabalho, levantam-se questionamentos que são temas de grandes debates na África, como a preocupação com os direitos da mulher sobre a terra, num ambiente em que se reconhece que aquela seja a principal usuária desta. Esse é um tema longe de ser encerrado, pois, ao avaliar o caso de Moçambique, o estudo encomendado pela Actionaid (2009), que visava colher informações sobre o estágio atual do direito da mulher à terra em Moçambique, mostrou que, em algumas regiões, o conhecimento da mulher com relação ao seu direito sobre a terra é ainda incipiente. De modo geral, o estudo constatou que as mulheres constituem o grupo que tem maior acesso ao uso da terra, sendo elas responsáveis pela garantia do sustento da família. Entretanto, o direito de controle ainda está no domínio do homem, cabendo a este a última decisão em relação ao que fazer com a produção, o que produzir e quando produzir.

O trabalho de Benjamim Alfredo (2009) contribuiu nas questões normativas de posse e uso de terra em Moçambique. Neste trabalho, o tema central abordou o regime jurídico moçambicano sobre a posse, uso e aproveitamento da terra e os conflitos emergentes, basicamente derivados das discrepâncias entre o sistema formal (Lei de Terras) e o sistema informal de ocupação de terras. A dualidade da posse de terra está também na pauta dos debates na África, especialmente na África Subsaariana, em que a maioria dos países sustenta-se pelas duas formas jurídicas nas questões da terra.

A segunda parte correspondeu às visitas às instituições governamentais e privadas, bem como a algumas organizações específicas de apoio à mulher no distrito de Inharrime. Essa fase ocorreu de dezembro de 2014 a fevereiro de 2015. O objetivo, aqui, era perceber onde a mulher em Inharrime encontrava apoios que pudessem proporcionar-lhe assessoria para a gestão dos conflitos sociais dentro da família, bem como os mecanismos formais em seu poder para o acesso e especialmente o controle 
da terra. Tinha-se em vista, ainda, saber o grau de mobilização das instituições na divulgação das leis formais e na assistência social às mulheres.

Essa foi a etapa mais difícil e com quase nenhum sucesso. Primeiro, os representantes das instituições governamentais mostravam-se reticentes em receber-me e, quando tal acontecia, apenas apresentavam discursos formais. Não aceitavam gravar as entrevistas, alegando que, de alguma forma, comprometia o seu posicionamento na instituição. Percebo, aqui, que o fato de as pesquisas de campo para fins acadêmicos ocorrerem ainda de forma esporádica no distrito pode ser a causa de pouca familiaridade com a forma de trabalho por mim apresentada. Em alguns casos, quando era sugerido o uso do gravador, a primeira preocupação era se não se tratava de um jornalista de rádio ou televisão.

A terceira etapa correspondeu à minha inserção no meio do grupo pesquisado, isto é, nas comunidades locais. Esta etapa do estudo foi realizada de forma contínua, iniciada bem antes do processo de estudo do doutorado, pelo fato de ser um local já frequentado por mim desde o meu casamento. Entretanto, para as questões do presente trabalho, foram realizados três contatos diretos, com a duração de aproximadamente três meses cada. Nesses três momentos, a observação foi participativa, com a realização de grupos focais e entrevistas às famílias, às mulheres e aos líderes comunitários.

\section{Considerações Gerais sobre o Método de Pesquisa}

Para a compreensão do tema em questão e privilegiando-me de estar em um programa de estudos interdisciplinares, a abordagem pluridisciplinar foi a estratégia utilizada. Combinou-se o interesse da história política, econômica e social envolvendo as questões da terra aos interesses sociais e antropológicos da sociedade moçambicana. O fato de ser difícil dissociar as questões da terra das circunstâncias e dinâmicas políticas, econômicas e sociais, bem como das estratégias da população frente aos sistemas políticos e econômicos distintos, tornou necessário o resgate dos momentos históricos de desenvolvimento político, econômico e social. Na mesma lógica, mostrouse necessário compreender e interpretar as práticas culturais e tradicionais, as percepções da vida social da comunidade numa relação de intersubjetividade minha com os diferentes grupos estudados, bem como a explicação minuciosa dos termos e 
contextos dos fatos verificados, o que conduziu ao recurso do método etnográfico diante da forma qualitativa das informações trazidas, que mais se basearam em relatos e discursos dos sujeitos pertencentes aos grupos estudados.

A técnica de pesquisa de campo e coleta de dados adotada foi a combinação entre a observação direta e participante, entrevistas e grupos focais. Durante os quatro anos de decurso do doutorado, a observação direta e participante ocorreu na rotina da comunidade em diferentes momentos do dia a dia das mulheres; em momentos de entretenimento e confraternização, em reuniões dos líderes comunitários, etc., ainda que de forma intercalada. William Foote Whyte, autor do clássico "Street corner society”, publicado orginalmente em 1943, tornou-se fonte inspiradora nos estudos qualitativos e pesquisa social, usando a observação direta como técnica de pesquisa. Do seu livro, Licia Valladares (2007) produziu uma resenha contendo 10 mandamentos para a observação participante, que foram a fonte de inspiração no processo da pesquisa de campo.

Sobre o tempo de pesquisa usando a observação, Valladares (2007) considera que a técnica acarreta um processo longo, com a necessidade, por vezes, de meses de negociação para a entrada do pesquisador no grupo, fato suplantado pela condição de esposa de um dos membros de uma das comunidades estudadas e por já participar de forma ativa na vida da comunidade, a exemplo de diversas cerimônias de evocação de defuntos, de lobolos, de casamentos, bem como encontros comunitários de resolução de conflitos em que me fiz presente na comunidade. A foto 1 reflete um dos momentos da minha integração na comunidade. 


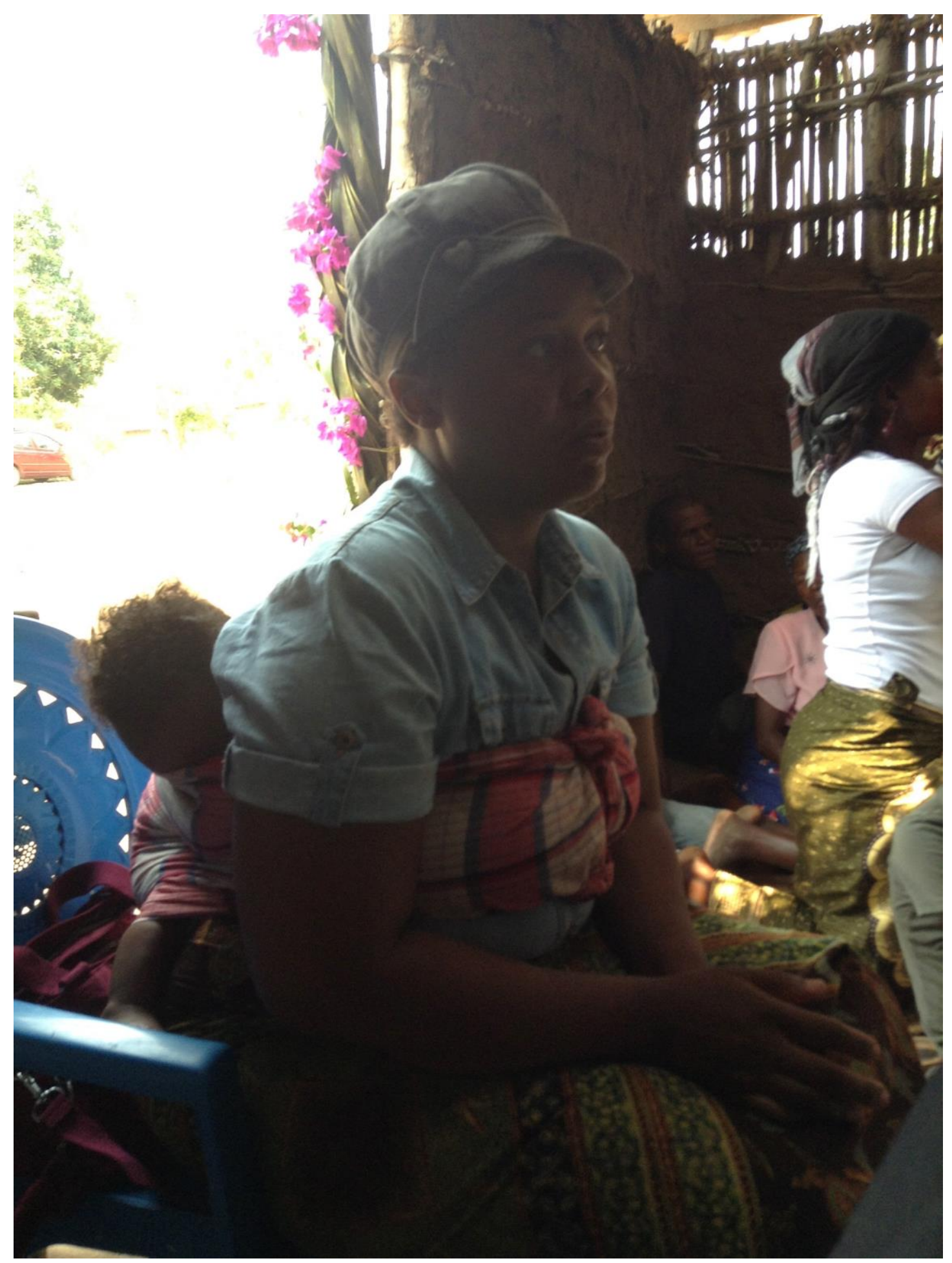

Foto 1. Assistindo a uma cerimônia de casamento em setembro de 2013 Fonte: A autora

Nesse contexto, a minha inserção no grupo, facilitada pelos laços de casamento, de certa forma me colocava como pesquisada em alguns momentos. Esse elemento me aproximou ainda mais do grupo, possibilitando o desenvolvimento de uma relação de amizade com certas mulheres que puderam me fornecer informações minuciosas de sua 
vida íntima, desejos, anseios e sentimentos pessoais, que sob outras circunstâncias não poderia obter.

Ao mesmo tempo, a minha qualidade de urbana (criada em uma família financeiramente estável e no contexto urbano), formada ${ }^{5}$ e independente financeiramente na mesma relação matrimonial me colocou numa condição diferente perante o pesquisado. Contudo, ainda que bem percebido esse distanciamento, tal condição mostrou-se poderosa na recolha dos dados, pois os informantes viam em mim a pessoa capaz de resolver seus problemas, colocando suas preocupações mais íntimas.

As entrevistas tiveram um caráter formal e informal. No geral, foram realizadas entrevistas formais, obedecendo a um questionário preestabelecido com três líderes comunitários e um secretário de bairro, com representantes da Organização da Mulher Moçambicana (OMM), dos serviços distritais de saúde, mulher e ação social, bem como dos serviços distritais de atividade econômica. Nesses organismos, pouco foi colhido que respondesse ao debate levantado na tese. As informações limitaram-se aos discursos formais, cautelosos e defensivos. Em grande parte, foram apenas de caráter oficioso, neutro em opiniões e posições pessoais com relação ao tema, havendo, portanto, relutância perante a hipótese de gravação dos encontros. Em regra, serviram para o aprofundamento da organização do distrito, conhecimento do grau de divulgação das leis, entre elas a lei da família e das terras, os projetos de ação social, o envolvimento dos serviços distritais na legalização dos direitos de uso e aproveitamento da terra em nível do distrito, bem como os quesitos necessários para a legalização dos direitos pelos seus usuários. Entrevistas informais foram realizadas com cinco famílias. Nesse caso, a conversa não foi individualizada, tendo a mesma ocorrido com todos os membros da família que se fizeram presentes. De forma individual, ocorreram 12 entrevistas informais com mulheres de diferentes comunidades.

Foi realizado, ainda, um grupo focal em combinação com a técnica de observação participante e entrevistas. $\mathrm{O}$ uso do grupo focal foi necessário na medida em que a técnica tem por objetivo:

(...) reunir informações detalhadas sobre um tópico específico (...) a partir de um grupo de participantes selecionados. Ele busca colher informações que possam proporcionar a compreensão de percepções, crenças, atitudes sobre o tema, produto ou serviço (TRAD, 2009, p. 780).

\footnotetext{
${ }^{5}$ Para muitos da comunidade pertencente ao meu marido, eu sou doutora, isto é, médica. A noção de nível acadêmico é pouco percebida e compreendida, daí que tornou-se comum, em qualquer situação de primeiros socorros, recorrerem à minha casa em busca de ajuda (medicamentos).
} 
O fato de pretender-se buscar percepções e atitudes das mulheres com relação às suas famílias, casamentos e/ou sobre si mesmas implicava, de certa forma, invadir a intimidade de cada mulher. Por isso, o uso do grupo focal foi a maneira eficaz encontrada para que as mulheres se libertassem e expusessem seus mais íntimos sentimentos, percepções e atitudes de forma mais natural possível.

A negociação para as entrevistas foi um o processo complicado, em termos de minha inserção nas instituições formais, pois, pelo fato de ser uma pesquisa para o doutorado, a ideia de que estariam se comprometendo com as informações fornecidas gerou dúvidas se deviam ou não me receber-me. Dentro das comunidades, a negociação foi mais simples, ainda que poucos percebessem a finalidade da minha pesquisa e a razão de serem entrevistas.

A seleção dos participantes do grupo focal é que foi um processo complexo. Os participantes selecionados foram apenas mulheres pertencentes à comunidade da qual faço parte, falantes da língua chope e que pouco ou quase nada sabem de português, língua oficial falada em Moçambique. Portanto, era fundamental que a moderação do grupo fosse feita na língua local, ou pelo menos nas duas línguas na mesma proporção. Com isso, primeiro tive de selecionar outro informante-chave, elemento previsto na técnica de observação que “(...) simboliza esse mediador que garante o bom acesso à localidade e/ou ao grupo social estudado" (VALLADARES, 2007, p. 153), que não fosse meu marido, mas que fosse igualmente de total confiança e com legitimidade dentro do grupo.

A seleção da pessoa certa para informante-chave, incluindo a seleção das mulheres participantes do grupo focal, ocorreu durante uma cerimônia de inauguração de um pequeno estabelecimento comercial de um dos líderes comunitários da comunidade da qual faço parte. Ao casarem, as mulheres se mudam para a casa do marido e lá formam o primeiro grupo dos casamentos da família, juntamente com as suas cunhadas, irmãs de seus maridos. Quando ocorrem eventos dessa natureza, é de praxe que as mulheres casadas, suas cunhadas, filhas e noras (que correspondem ao segundo grupo de casamentos da família) realizem tarefas de apoio na casa do anfitrião, para o bom decurso da cerimônia. Dessas tarefas inclui-se a busca de água, lenha e condimento dos alimentos para a festa, enquanto os homens cuidam do sacrifício do animal e as anciãs dormem ou cuidam das crianças, exemplos mostrados na foto 2. Como membro da comunidade e pelo interesse que tinha com a observação direta dessas mulheres, participei no processo de interajuda compondo o grupo que cuidaria 
da comida da festa, ainda que, no final, todas as outras mulheres se ajuntassem para a limpeza da cozinha.

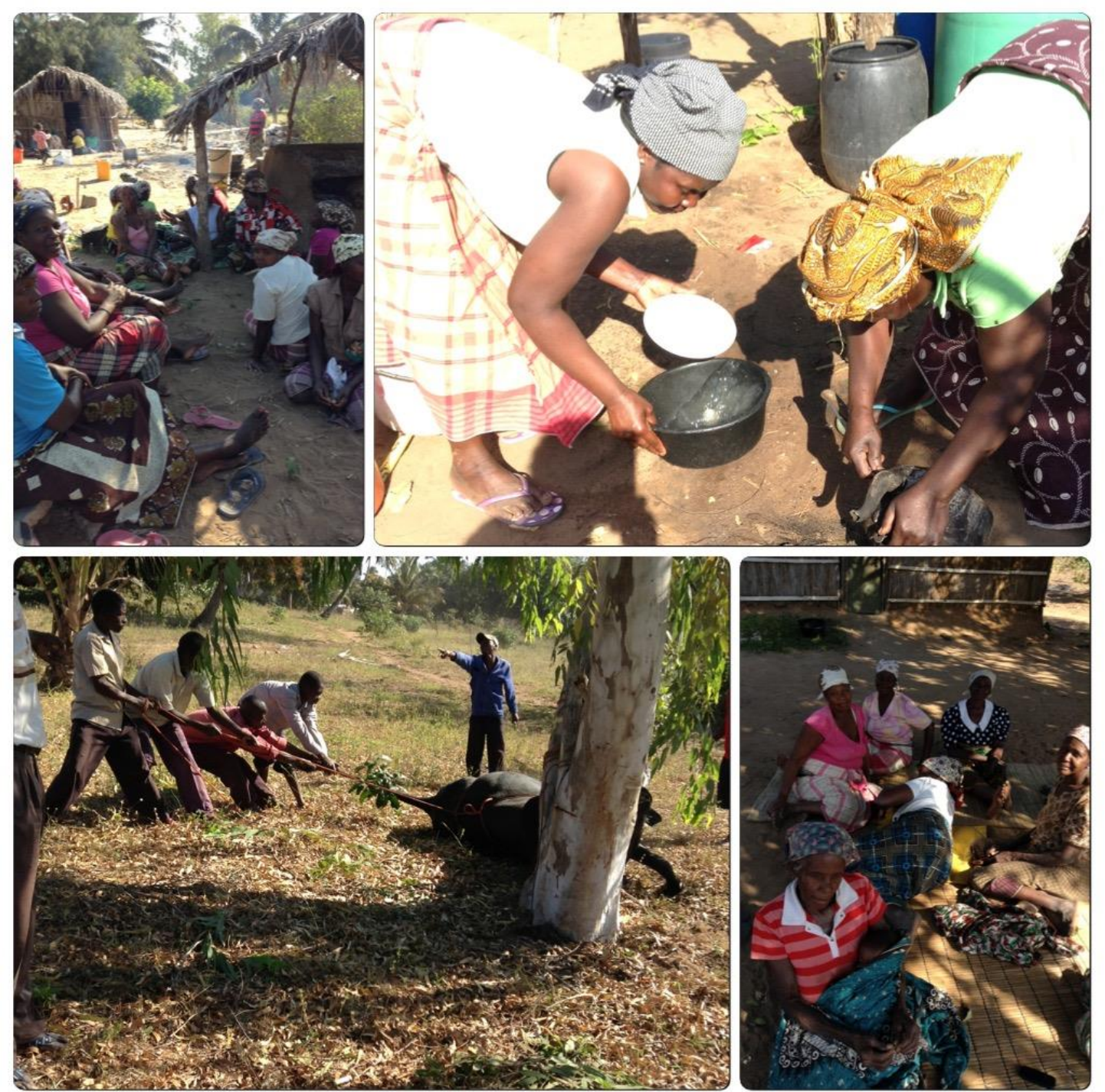

Foto 2. Atividades festivas

Fonte: A autora

Faz parte da tradição, depois de confeccionados os alimentos, servir-se em primeiro lugar aos Nhandibande, Wa hombe, Madodas, aos homens que cuidaram e/ou cuidam de outras atividades da festa, às crianças, ao restante dos convidados, e, por último, nós, mulheres, que cuidamos das tarefas da cozinha. Na minha opinião, essa é a parte mais ingrata da distribuição dos alimentos, pois, por vezes, as mulheres acabam tendo de fazer outra comida complementar, pois, do prato principal (o boi que geralmente é sacrificado para a cerimônia), pouco sobra para elas. Das bebidas alcoólicas da festa, nenhuma chega a ser oferecida às mulheres. Tornou-se comum em ocasiões de festas, especialmente aquelas sob o meu domínio, oferecer à parte esses 
elementos a elas excluídos. Feita a cerimônia, ofereci aos meus pares a bebida comprada do próprio estabelecimento, com a condição de que o consumo seria feito apenas por nós, mulheres daquele grupo de trabalho. Surge, nesse instante, em decisão unânime, a mulher que deveria ser responsável pelo dinheiro da compra da bebida, dada a condição de ser a que não consumia bebida alcoólica e ter integridade moral e respeito por todas para ser a guardiã do dinheiro e da bebida do grupo.

Da decisão relatada acima, pude também selecionar meu segundo informantechave, que atuou ainda como segundo moderador, apoiando na tradução, explicação das questões mal percebidas, como a da guardiã do dinheiro e da bebida do grupo de mulheres, entre outras tarefas. A outra grande sacada foi perceber que os participantes ideais para o grupo focal seriam os componentes do primeiro grupo das mulheres de trabalho, as mulheres casadas e noras de primeiro grau, grupo este no qual estou enquadrada, bem como as filhas (cunhadas destas). Com a colaboração do segundo informante-chave, foram levadas a cabo as negociações para a seleção do número e perfil desejado, afinal, segundo Valladares (2007):

Considerando que os participantes do grupo devem ser competentes para posicionarem-se diante das temáticas a serem abordadas na pesquisa, é conveniente nesta fase realizar algumas consultas com informantes-chave que conheçam particularidades do fenômeno, situação em estudo ou do universo a ser pesquisado (VALLADARES, 2007, p. 785).

Portanto, os elementos que compuseram o grupo focal eram mulheres, na faixa etária de 25 a 55 anos, que estivessem na condição atual de noras em primeira linha em seus lares, ou filhas na condição de viúvas e/ou divorciadas que teriam regressado à casa de seus progenitores, ou que tivessem permanecido em suas famílias receptoras. A condição de apenas participar um elemento por cada família também serviu de critério de seleção, isto é, o privilégio era dado inicialmente à nora, obedecendo a faixa etária estabelecida. Se, por um lado, na mesma família existisse uma filha regressada do lar, esta era automaticamente excluída, pois supunha-se que intimidaria a cunhada, o elemento principal. Por outro, no caso de a nora estar fora da faixa etária, ou no limite desta, privilegiava-se a participação da cunhada (a filha divorciada, viúva, abandonada, etc.). Não foi selecionado nenhum elemento da família direta do meu marido (irmãs, cunhadas esposas dos irmãos ou dos primos em primeiro grau, etc.).

A pesquisa com o grupo focal ocorreu no espaço da minha residência, sob condição de não se encontrar presente nenhum elemento do sexo masculino de 
nenhuma das partes, incluindo meu marido e filhos. O encontro teve a duração de sete horas, com intervalos para o lanche da manhã e o almoço, refeições confeccionadas por pessoas totalmente neutras à família. Era a temática da pesquisa: duas empregadas domésticas, uma recrutada no nível local e a outra que me acompanha desde o início do meu casamento. A foto 3 mostra grupo das mulheres constituintes do grupo focal.

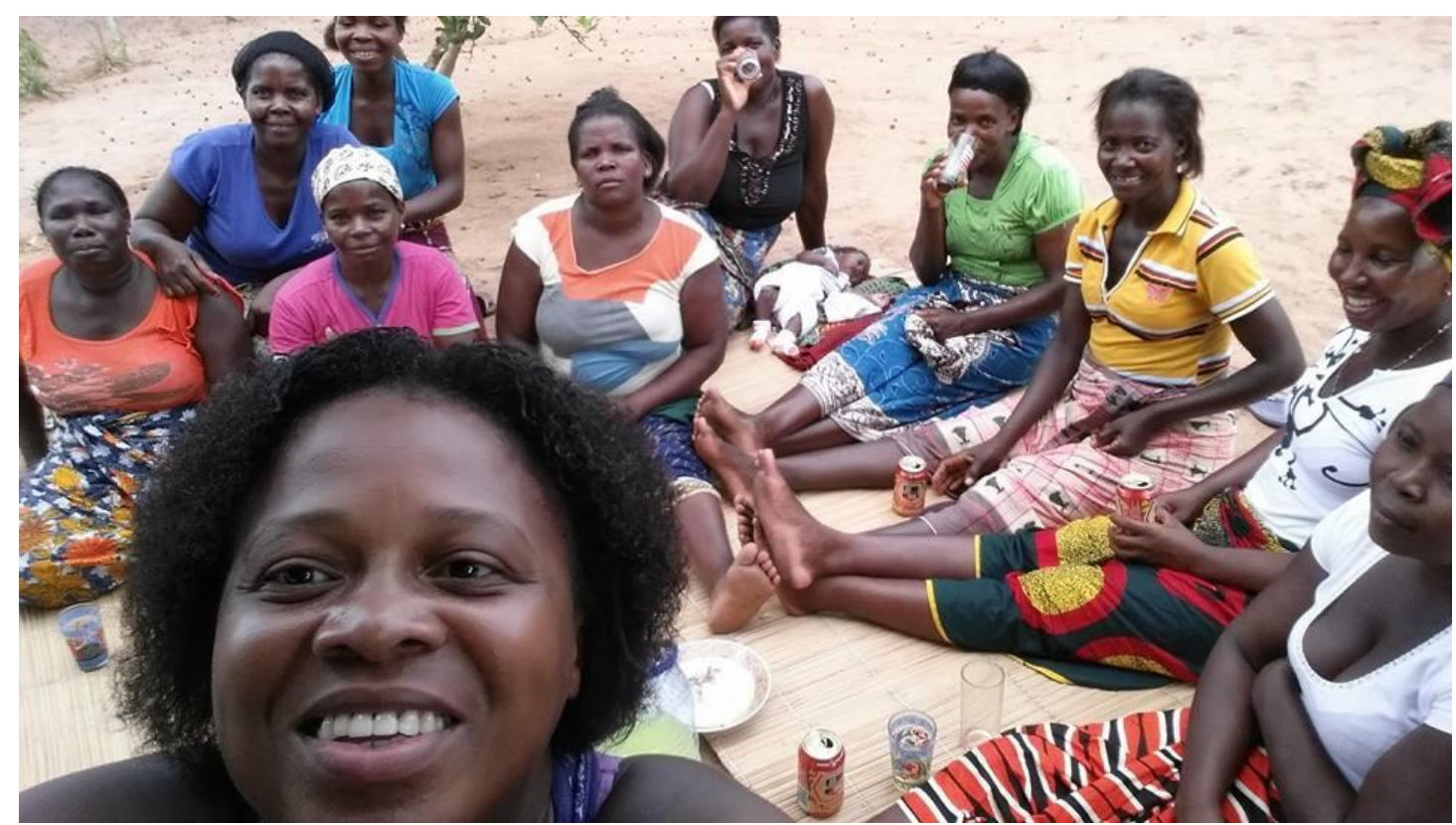

Foto 3. Elementos do grupo focal

Fonte: A autora 


\section{Estrutura da Tese}

O trabalho compõe uma introdução, três capítulos e uma conclusão. O primeiro capítulo, intitulado "A Teoria da Dependência e Dependência em Moçambique”, tem como objetivo contextualizar o país no seu processo histórico de desenvolvimento econômico, social e político. Explora os conceitos fundamentais da teoria da dependência, no sentido de resgatar a origem da dependência econômica externa em Moçambique. Em seguida, o capítulo trata da questão da dependência, em distintos momentos históricos, mostrando como as políticas adotadas transformaram as relações sociais e afetaram a visão sobre a vida, ou seja, o sentido de existência humana para o povo, especialmente no mundo rural. O segundo capítulo, intitulado "A Origem e Formação da Família em Moçambique", tem por objetivo explorar a questão da família como local primordial de reprodução social e célula básica da sociedade. Nesse capítulo, faz-se uma reflexão, partindo dos contextos universais da gênese da família, segundo Engels (1987), dos modelos apresentados no contexto das famílias africanas, no contexto geral das famílias moçambicanas, especialmente a comunidade chope de Inharrime. Em seguida, debruça-se sobre a questão da mulher, mostrando os parâmetros do envolvimento desta junto à sua comunidade, assim como na forma como a mulher se posiciona no contexto familiar, os locais e condições em que esta exerce o poder e autonomia no contexto da cultura chope. O terceiro capítulo intitulado "As Formas de Acesso, Posse e Controle de Terra em Moçambique", trata das questões da terra, os regimes jurídicos e tradicionais de acesso, posse e controle da terra, dentro do contexto da dualidade de regimes verificado em Moçambique. Nesse capítulo, são ainda explorados os exemplos verificados no trabalho de campo, no aspecto do acesso, posse e controle da terra pelas mulheres, diante das relações em estas se encontram envolvidas junto à família e à comunidade em que se inserem. Finalmente, é apresentada a conclusão da tese, na qual procuro cruzar os dados dos três capítulos, mostrando como isso afeta o campo do acesso, posse e controle da terra no âmbito geral e especialmente para a mulher. Ao mesmo tempo, são mostradas as estratégias possíveis, bem como as que são apresentadas pelas mulheres em Inharrime, no sentido de contornarem as dificuldades apresentadas em nível das tradições e/ou usadas em seus contextos familiares para se adaptarem ao modo de vida a elas apresentadas, e que sustentem o argumento central da tese. 


\section{Introdução}

Os 40 anos de independência de Moçambique são repletos de conquistas que marcam a identidade dos moçambicanos como povo. O país passou por um período longo de colonização, precisando enfrentar um conflito armado para a conquista da sua liberdade. Na tentativa de ser dono de si mesmo, o país acabou abraçando os ideais do bloco socialista, culminando na adoção do Estado Marxista-Leninista. Bem antes que pudessem ser percebidos os efeitos das políticas desenhadas em tentativa de implementação, inicia em Moçambique uma guerra civil que confrontou, na altura, o governo da FRELIMO e da atual RENAMO.

Na sequência, a falta de alternativas fez com que os governantes aceitassem um plano de reformas econômica e social, na esperança de conseguirem benefícios econômicos que melhorassem as taxas de crescimento, assim como as condições de vida do seu povo, que mergulhava num contexto de pobreza extrema diante de tantas modificações que para si se apresentavam. O plano de reforma mergulhou o país num mundo de dependência crônica de ajuda externa.

Por muito tempo me mantive na concepção de que a dependência externa teria iniciado nesse contexto dos preceitos da economia voltada para o mercado. No entanto, a literatura mostrou que talvez fosse interessante fazer um recuo nas formas de atuação dos distintos governos em momentos históricos pelos quais passamos e encontrar a gênese dessa "doença" que insiste em se manter no país e que, sem querer ou perceber, o vai afetando, especialmente no meio rural, na forma como encara-se a vida, no trabalho, bem como na família, criando e recriando alternativas que possam manter as pessoas vivas nesse contexto de mudanças.

É dentro dessa lógica que este capítulo trata da questão da dependência. Traz os diversos momentos históricos, mostrando como as políticas adotadas transformaram as relações sociais, bem como as decisões individuais do povo, especialmente no mundo rural. 


\subsection{Os Preceitos da Teoria da Dependência}

De acordo com Dougherty e Pfaltzgraff (2003), a teoria da dependência foi desenvolvida pela Comissão Econômica para a América Latina (CEPAL). A tese defendida é de que a dependência, enquanto estrutura mundial, é distinta do estado de dependência que liga os países uns aos outros. A CEPAL dividia o mundo em dois polos: o centro e a periferia. As estruturas de produção desses dois polos irão se diferenciar significativamente, tendo o centro uma estrutura diversificada e a periferia uma estrutura especializada, em que as relações se caracterizavam pela troca de produtos manufaturados por alimentos e matérias-primas.

Focando especialmente na América Latina, Marini (2000) comenta que, como periferia, a América Latina se desenvolve em estreita consonância com a dinâmica do capitalismo internacional. Disso constatou-se que as relações da América Latina com os centros europeus se inserem em uma estrutura definida, resultante da divisão internacional do trabalho a ela conferida como colônia, produtora de metais preciosos e gêneros exóticos e como produtora e exportadora de bens primários.

Das leituras de Nipassa (2009), percebe-se que a teoria da dependência encontra três desdobramentos: subdesenvolvimento dependente, desenvolvimento dependente e reversão da dependência. $\mathrm{O}$ argumento central seria que

o sistema capitalista global, ampla mas não exclusivamente através das corporações transnacionais, opera ativamente para sub desenvolver o terceiro mundo e que nenhum crescimento genuíno era possível enquanto sobrevivesse o sistema (NIPASSA, 2009, p. 10)

Para Nipassa (2009), sendo o estado de dependência resultado de constrangimentos estruturais, será praticamente impossível que um país pobre saia da condição dependente, pois isso não consta nos planos da estrutura econômica internacional.

Essa visão sobre a dependência foi também observada por Marini (2000), que entendia a dependência como uma relação de subordinação entre nações formalmente independentes, em cujo âmbito as relações de produção das nações subordinadas são modificadas e recriadas para assegurar a reprodução ampliada da dependência. Assim, se o estado de dependência está inteiramente ligado a necessidades subjacentes a uma determinada relação de produção, sua liquidação estará condicionada, necessariamente, à supressão dessas relações que ela supõe. 
Marini (2000) explica a gênese da dependência por via da mais-valia relativa que se dá com a exploração do trabalhador. Direcionado ao estudo da realidade latinoamericana, o autor explica que essas economias, além de responderem ao que é exigido para a acumulação dos países industriais, tinham como função, na economia capitalista, facilitar o crescimento quantitativo destes e contribuir para que o eixo da acumulação na economia industrial se deslocasse da produção de mais-valia absoluta à mais valiarelativa. Dessa forma, uma vez que a acumulação passa a depender mais do aumento da capacidade produtiva do trabalho, ocorre, assim, uma maior exploração do trabalhador.

Nessa lógica, diante das desigualdades da capacidade industrial dos países da América Latina com relação aos países industriais, argumenta Marini (2000), verificase a deterioração comercial que vai, então, forçar essas economias a produzir em maior escala. Ao invés de essas nações desfavorecidas buscarem corrigir o desequilíbrio entre o preço e o valor das suas mercadorias exportadas, elas buscaram compensar a perda da renda gerada pelo comércio internacional através do recurso a uma maior exploração do trabalhador, que se deu pelo aumento da intensidade de trabalho, que consequentemente gerou um aumento da mais-valia. Assim, a indústria da América Latina seguiu especializada na atividade subordinada à produção e à exportação de bens primários, que constituíam o centro vital do processo de acumulação. Isso explica o forte desenvolvimento da economia exportadora da América Latina.

$\mathrm{Na}$ África, especialmente em Moçambique, o estado de dependência atual se dá por meio de ajuda externa para o desenvolvimento, também designada ajuda pública ao desenvolvimento. Ela consiste na transferência de recursos de um país para o outro, a fim de promover o desenvolvimento no país receptor.

Para Marini (2012), os programas de ajuda externa derivam de um plano norteamericano (EUA) de reorganização da economia mundial, realizado em benefício do capital norte-americano, depois de sucessivas crises que abalaram o mundo da economia capitalista internacional. Na onda de recuperação geral, Marini (2012) afirma que coube aos EUA a tarefa de reorganizar a economia capitalista, pois, dotados de uma economia imperialista, estariam capacitados a reestabelecer o funcionamento normal do mercado internacional mediante um contínuo investimento dos enormes excedentes comerciais que a capacidade da sua própria economia criava, bem como ampliando o raio para a acumulação do capital que pudesse absorver a produção em massa de dinheiro gerado pela sua prosperidade. Marini (2012) acrescenta que é sobre a base da 
reorganização da economia capitalista mundial e da expansão monetária que se dá a ampliação progressiva do raio de acumulação do capital privado norte-americano.

Nesse contexto de reorganização da economia internacional, os EUA contaram, por um lado, com organismos de intervenção multilateral criados no âmbito da conferência de Bretton Woods em 1944, nomeadamente: (i) o Fundo Monetário Internacional - FMI e o Banco Mundial - BM, onde o FMI respondia pelo financiamento dos déficits dos balanços de pagamento, utilizando as reservas mundiais em seu poder, a fim de impedir possíveis obstáculos à circulação internacional do capital; (ii) o Banco Internacional de Reconstrução e Desenvolvimento - BIRD, com a tarefa de financiar projetos de desenvolvimento econômico que criassem condições para a rentabilidade do capital privado; e, (iii) em 1947, o Acordo Geral sobre Tarifas Econômicas - GATT, em que, por meio do referido acordo, os EUA puderam impor o livre comércio e suprir as barreiras alfandegárias que, a priori, dificultavam o fluxo das suas exportações. Por outro lado, a intervenção dos organismos internacionais possibilitaram que os EUA focassem e expandissem seus planos de ajuda externa, econômica e militar (MARINI, 2012).

Entretanto, a ajuda externa representa um componente fundamental de cooperação para o desenvolvimento dos países, não importando se é de ordem pública ou privada, exercida por via de instituições governamentais e não-governamentais, de ordem empresarial ou ainda de cooperação entre os países do Norte-Sul ou Sul-Sul, incluindo a cooperação como fenômeno de ajuda (NIPASSA, 2009). De acordo com Melani (2012),

\begin{abstract}
a cooperação internacional para o desenvolvimento (CID) pode ser definida como um sistema que articula as políticas dos Estados e atores não governamentais, um conjunto de normas difundidas (ou em alguns casos prescritas) por organizações internacionais e a crença de que a promoção do desenvolvimento em bases solidarias seria uma solução desejável para as contradições e as desigualdades chegaras pelo capitalismo no plano internacional (MELANI, 2012, p. 211).
\end{abstract}

No entanto, importa salientar que a cooperação como fenômeno de ajuda não significa uma relação de reciprocidade, como acontece com os outros tipos de cooperação. Esta se dá de forma unívoca, em que, tecnicamente, o país doador não deveria esperar nenhuma forma de contrapartida do país receptor, como assim afirma Nipassa (2009).

De acordo com Nipassa (2009), o que mais se observa é que a ajuda externa acaba sendo sempre motivada, respondendo aos interesses próprios dos países doadores, que 
vão desde a procura de novos mercados e áreas de expansão para as suas indústrias nacionais até os interesses de política externa que reforcem suas posições no seio da comunidade internacional (NIPASSA, 2009). Sobre esta posição, Marini (2012) adverte que, na intervenção das multinacionais ou empresas transnacionais, aquelas com $25 \%$ ou mais do seu investimento, produção, emprego ou vendas no exterior, geradas na sua maioria pelas mudanças nas exportações de capital para o exterior, as razões para a intervenção focam especialmente na:

1. rentabilidade da empresa, o efeito que a taxa de lucro representa para a empresa que conta com as infraestruturas de transporte e energia, existência de matéria prima, bem como do custo de mão de obra do pais receptor;

2. capacidade do mercado;

3. capacidade de aumento das indústrias de bens de capital ou correlatas (material bélico);

4. possibilidade de crescimento da produção, especialmente em setores de eletrônica, de química pesada, de máquinas e ferramentas, etc.

De certa forma, estes aspectos constituem uma exigência para que os Estados nacionais receptores da ajuda se empenhem na sua capacidade de criar infraestruturas, proteger e defender o mercado interno nas negociações financeiras e comerciais com o exterior e criar condições políticas favoráveis ao investimento estrangeiro. Tais ações são de ordem estritamente econômicas, que do ponto de vista social pouco ou quase nada contribuem para o bem estar da população afetada pela ajuda. Na verdade, o que mais faz além do reescalonamento dos países, sob ponto de vista da sua capacidade de acumulação, é gerar e encorajar uma competição entre os países receptores da ajuda de forma a se tornarem elegíveis a empréstimos adicionais (MARINI, 2012; CASTELBRANCO, 2011).

Adicionalmente, o impacto que a ajuda externa pode gerar na economia mundial é, segundo Nipassa (2009), corroborando as opiniões mostradas por Marini (2012) e Castel-Branco (2011), o de estruturar as relações entre países, identificando-se, por um lado, o movimento dos países desenvolvidos, aqueles que ajudam e que, por isso, têm aptidão para lidar com o mundo, sendo a eles reconhecidas formas superiores de organização social, política e econômica. Por outro lado, estariam identificados os países pobres e subdesenvolvidos, aqueles que são ajudados e, por isso, não lhes são reconhecidas certas capacidades, como as de lidar com o mundo, bem como com as formas de organização que são consideradas inferiores. 
Na verdade, o argumento que Castel-Branco (2011) apresenta é que, diante da fragilidade e fragmentação das instituições do governo, em consequência da ajuda recebida, a preocupação para com a proteção dos interesses do capital e a adoção, por exemplo, de uma legislação laboral e de investimento estrangeiro mais liberal têm constituído um critério para a classificação da política econômica em "boa" ou "má". Ora, com todos fatos expostos, vale dizer que ser ajudado significa admitir um estado de incapacidade total, ao mesmo tempo em que o país, dado o seu estado de dependência, acaba se sujeitando a situações de humilhação.

Diante do exposto, Castel-Branco (2011) toma Moçambique como um bom exemplo para o estudo da dependência. Afinal, a ajuda externa em Moçambique persiste por décadas, a ponto de se tornar multidimensional, estrutural e dinâmica. $\mathrm{O}$ apoio a Moçambique por parte da comunidade internacional acontece especialmente por via de donativos e do crédito, o que deveria se refletir positivamente no desenvolvimento do país. Entretanto, ao contrário de uma resposta positiva junto à população local, vemos agravarem-se carências alimentares, problemas nas áreas da saúde, educação, habitação e emprego. Essa situação só vem a sustentar o posicionamento de Nipassa (2009), de que quanto mais ajuda Moçambique recebe, mais dependente se torna, pois, nas condições em que a ajuda é cedida ao país, viabilizase o domínio dos doadores, estrangula o sentido de dignidade, limita a autonomia do indivíduo, bem como compromete a possibilidade de os moçambicanos construírem o seu próprio desenvolvimento.

Entretanto, contrariamente ao que pode se observar nos meandros da dependência externa, em países extremamente pobres e vulneráveis, potências médias emergiram-se da condição de periféricas à condição de potências globais, "favorecidas" pelo fato de poderem se inserir no contexto da economia capitalista internacional, ainda que na forma de economias dependentes, porém, com a possibilidade de exercerem uma política expansionista autônoma. Foi o caso mostrado por Marini (2012), sobre algumas economias latino-americanas como o Brasil, que diante das mudanças ocorridas na economia capitalista no período da crise mundial entre guerras, aproveitaram para impulsionar o processo de industrialização, fortalecendo, assim, sua indústria manufatureira. Ainda que as economias emergentes, à semelhança do Brasil, estivessem em condição de dependentes ao capitalismo internacional, ou seja, num contexto de "capitalismo dependente", que segundo Luce (2011) se caracteriza pela superexploração da força de trabalho aliado ao divórcio gerado por essa condição entre 
a estrutura produtiva e necessidades de consumo das amplas massas, pela industrialização, tais economias têm a possibilidade de se projetar como subimperialista ao exercerem uma política expansionista relativamente autônoma. Tal política, apesar de manter-se no marco da hegemonia exercida pelo imperialismo dominante, permite manobrar conquistas no contexto da esfera de influência própria.

Na verdade, o termo "subimperialismo" foi cunhado por Marini (2012). Segundo o autor, a crescente expansão e a acelerada circulação tanto do capital produtivo como do capital dinheiro, apresentaram-se como condições para a configuração de uma nova economia mundial capitalista baseada num esquema de divisão internacional do trabalho. Nesse contexto, o modelo simples centro-periferia daria lugar a uma realidade em que a indústria toma todas as atenções, amplia e se fortalece para as áreas extrativas e agrícolas, originando um reescalonamento e hierarquização dos países capitalistas na forma piramidal, bem como tornando possível o aparecimento de centros medianos de acumulação, o que remete à ideia da emergência do subimperialismo. Assim, para Marini (2012, p. 59) o subimperialismo é "a forma que assume a economia dependente ao chegar à etapa dos monopólios e do capital financeiro", devendo a economia mostrar uma composição orgânica média na escala mundial dos aparatos produtivos nacionais e o exercício de uma política expansionista relativamente autônoma, acompanhada de uma maior integração do sistema produtivo imperialista.

De acordo com Luce (2011), o subimperialismo pode ser entendido pela combinação de quatro variáveis, que são:

1. A composição orgânica média nacional do capital - esta variável traduz a posição de um sub-centro econômico de acumulação mundial na divisão internacional do trabalho no interior do sistema mundial diferenciado. De acordo com Luce (2011), esse aspecto teria o mesmo sentido do que Marini (2012) considerou o grau de operação do capital financeiro dos monopólios capitalistas na economia dependente, ao que lhes imputa equivalência de sentido - composição orgânica média/monopólio e capital financeiro;

2. Esquema tripartite de realização de mercadorias - esta variável consiste na presença de um mercado externo, o Estado e o consumo santuário que definese como "produto a cujo consumo não tem acesso, em grau significativo, as massas trabalhadoras" (LUCE, 2011, p. 6, nota 8 apud ACMyS, p. 27, nota 26);

3. Hegemonia em um subsistema de poder; 
4. Presença de uma política de cooperação antagônica de um dado país com relação ao imperialismo dominante. Esta variável conta, sobremaneira, com a ação do Estado, lançando mão de uma política que vise a melhorar relativamente suas condições no marco da sua dependência.

Portanto, o que vemos como tendência atual, especialmente na África, são potências médias como o Brasil, a Índia e a China aumentando bastante sua presença em países mais vulneráveis, especialmente nos países africanos de renda extremamente baixa, por meio de acordos de cooperação, bem como por via de inserção de grandes empresas transnacionais. Para Marini (2012), essa ascensão das nações emergentes acaba sendo baseada na exportação dos seus setores mais populares e nos países onde atuam, convertendo estes últimos em países periféricos das nações emergentes. Ainda que cercadas de inúmeras críticas à sua atuação e intenções, como se fossem unicamente para o seu enriquecimento e transnacionalização do capital, é fato que esses países representam uma alternativa contra a ajuda externa dos doadores tradicionais. Cita-se, por exemplo, a expansão do grupo BRIC (Brasil, Rússia, Índia e China) como uma força em ascensão capaz de se tornar economicamente a maior do mundo em 2050 (CICHAVA, 2011). As crescentes relações desse grupo com o continente africano já elevaram sobremaneira o volume do comércio, melhorando suas posições na lista dos maiores parceiros econômicos da África, com a China em $2^{\circ}$ lugar, a Índia em $6^{\circ}$, o Brasil em $10^{\circ}$ e a Rússia em $15^{\circ}$ (CHICHAVA, 2011).

Entretanto, o que se discute na literatura é que, à semelhança do que acontece com as condições impostas para receber ajuda externa, oferecida pelos países doadores tradicionais, essas economias emergentes acabam, ainda que maquiadas de discursos solidários para o benefício social, canalizando, da mesma forma, para o enriquecimento e a transnacionalização do seu capital sem, no entanto, representar benefícios equivalentes para as economias onde estão assentes, aspecto esse que autores como Marini (2012) consideraram um ato característico da tendência subimperialista. 


\subsection{A Gênese da Dependência em Moçambique e Seu Impacto nas Relações Comunitárias}

Ainda que diversos autores contabilizem um processo de ajuda externa para o desenvolvimento de Moçambique a partir de seu início em 1975, mediante apoio da então União Soviética, China, dos países nórdicos e por parte de alguns movimentos progressistas dos Estados Unidos e da Europa, outros autores recuam para um período ainda dentro do contexto da colonização portuguesa em Moçambique. Afinal, vale lembrar que a economia de Moçambique emerge de um contex to típico de dependência aos modelos ocidentais, ditados pela política colonial portuguesa no país. Tal como em diversos países ocidentais, no século XIX, Portugal também se refinou de forma a se adequar ao modo de produção capitalista, sistema que nada mais é que um cedente processo de acumulação sustentado pela propriedade privada dos meios de produção e exploração do trabalho (NETTO e BRAZ, 2012). Cabaço (2007) lembra que, até a metade do século XIX, Portugal ainda não tinha ocupado efetivamente o território moçambicano. Portugal passava por uma crise socioeconômica por conta da formação do capitalismo no país, bem como por outros fatores, como a revolução mineira e o início da industrialização na vizinha África do Sul, que teve um papel fundamental para as transformações que iriam ocorrer em Moçambique com as políticas coloniais.

Com a abolição da escravatura e na perspectiva de criação de riquezas para a acumulação capitalista, Portugal acabou adotando em suas terras colonizadas, especialmente em Moçambique, a política civilizadora através do trabalho assalariado e a atração do investimento das empresas estrangeiras para as grandes plantações, extração mineira, comércio exterior, serviços como o hinterland, entre outras áreas favoráveis ao investimento. Dessa forma, o território passa a ser dividido de acordo com as suas potencialidades, para a possibilidade de acumulação de Portugal. Assim, o Sul do país se torna o foco de prioridade no processo de ocupação portuguesa, pois aqui se concentrava a principal pressão britânica, era o centro dos lucros gerados pelo recrutamento da força de trabalho para a África do Sul, bem como das receitas das tarifas de trânsito dos produtos sul africanos que usavam o porto de Lourenço Marques. Enquanto isso, no Centro e no Norte do país se concentraram as grandes concessões de terras com amplos poderes administrativos, pois nelas havia cobrança de impostos, negociavam-se as formas de exploração do solo, do subsolo e das riquezas marítimas, 
e a elas estavam garantidos os direitos de exclusividade no recrutamento de mão de obra, bem como na emissão de moeda, selos postais nos territórios da sua administração. (CABAÇO, 2007; HERNÁNDEZ, 2009).

Hernández (2009) considera que essa substituição de uma imagem do escravo para um trabalhador livre enquadrava-se dentro de uma política de trabalho como caminho adequado para a incorporação dos negros africanos nessa nova ordem econômica - a capitalista. Entretanto, isso não significou a criação de uma classe trabalhadora, fosse ela urbana ou rural. Tal incorporação consolidou-se estruturalmente com uma dicotomia entre o indígena e não-indígena, civilizado e não-civilizado, assimilado e não assimilado, destruindo todos os poderes locais, gerando a subordinação das suas organizações políticas e sociais aos parâmetros e valores do colonialista (CABAÇO, 2007; FARRÉ 2008; MENESES 2009). No entanto, contraditório foi prevalecer o igualitarismo rigoroso, que considerava que "(...) todo o habitante de Portugal era português em qualquer dos seus territórios" (FARRÉ, 2008, p. 398-399), fato que gerou ausência de critérios coerentes de direitos e/ou separação de direitos que constituiriam a cidadania moçambicana em favor da cidadania portuguesa. Para Hernández (2009), o indígena, ainda que supostamente fosse considerado trabalhador livre, tampouco possuía o estatuto de cidadão pleno português. Cabaço (2007) acrescenta que o indígena estava mais submetido a um sistema jurídico culturalmente bastante complexo:

1. Do ponto de vista laboral, a legislação aplicada obedecia estritamente a conceitos europeus e respondia às necessidades da metrópole;

2. Do ponto de vista do direito público e criminal, o quadro legal a que se subordinava dependia da especificidade da colônia, e;

3. Nas questões do direito privado, os "usos e costumes" do seu agrupamento gentílico prevaleciam domésticos ou sociais, desde que não ofendessem os direitos de soberania nacional ou não repugnassem os princípios da humanidade.

$\mathrm{Na}$ verdade, esta foi a forma mais explícita que Portugal usou para mostrar que havia uma inferioridade dos súditos africanos, justificando, por isso, a presença europeia para uma missão civilizadora. Tal aconteceria ainda com a emancipação dos indígenas das "trevas", das suas culturas que simplesmente foram reduzidas a um 
conjunto de usos e costumes tradicionais (CABAÇO, 2007; HERNÁNDEZ, 2009, DIREITO, 2013).

Para Meneses (2010), essa missão colonial em Moçambique com o rótulo de libertar os indígenas locais da barbárie, nada mais era que tornar os nativos "seres mais evoluídos", ao ensinar-lhes o tempo da modernidade, ou seja, torná-los seres civilizados. Para isso, precisavam não apenas do controle do espaço, mas do próprio corpo humano, do comportamento e das ações, sendo elas definidas a partir da Europa, o cânone do progresso e da civilização. Portanto, tudo que aparecesse e se mostrasse diferente era bárbaro e atrasado.

Tal qual Hernández (2009), Meneses (2010) corrobora o fato de a política portuguesa ter se centrado no trabalho ou na sua exploração como forma de atingir o "desenvolvimento de Moçambique" e, consequentemente, como forma de tornar os indígenas civilizados, mostrando o domínio da legislação, que previa o

(...) dever moral do governo colonial em desenvolver as propensões morais dos indígenas encorajando-os a cumprir as suas obrigações morais de melhoria das suas condições de vida através do engajamento em atividades laborais compulsivas, durante seis meses por ano (MENESES, 2010, p. 75).

$\mathrm{Na}$ verdade, isso prova que a tese vinculada ao trabalho como meio para a civilização iria justificar o regime explorador da força de trabalho, maquiado na intenção de desenvolver Moçambique, mas que pudesse de forma rápida responder aos interesses acumulativos da Europa. Na sequência, continua Meneses:

(...) todos os indígenas das províncias ultramarinas portuguesas estariam sujeitos à obrigação moral e legal de adquirir pelo trabalho os meios que lhes faltassem para substituir e melhorar a própria condição social, tendo plena liberdade de escolherem o modo de cumprir essa obrigação, o que, se não fosse feito, poderia ser-lhes imposto pelas autoridades. Este código, ao qual se seguiram outros, estabelecia que a obrigação do trabalho era vista como cumprida quando, a critério das autoridades locais, os indígenas provassem ter capital suficiente, ter produzido bens de exportação, ter cultivado terras por conta própria em quantidade e dimensão fixadas pela administração, ou o exercício de ofício ou profissão que lhes garantisse, a si e a seus familiares, níveis de vida compatíveis com os padrões civilizados (MENESES, 2010, p. 76). 
Nesta perspectiva, foram legitimadas as práticas mais hediondas da exploração em Moçambique: o trabalho forçado $\left(X_{i b a l o}{ }^{6}\right.$ ), os impostos, os castigos corporais, a inaplicabilidade ao indígena dos direitos humanos e dos princípios cristãos, isso nas relações de produção indígenas. Para Cabaço (2007, p 160), a própria representação do indígena criou-se não o observando como um indivíduo, mas como alguém inserido numa comunidade: “(...) sem história, sem sentido de Estado, sem valores éticos, sem economia, isto é, sem civilização. O interlocutor do colonialismo era a tribo, não o indivíduo. Esse só ganhava existência quando se assimilava (...)”. Entretanto, vários autores, à semelhança de Cabaço (2007) e Hernández (2009), convergem para o posicionamento de que já se observava uma total dependência da economia moçambicana aos modelos de economia ocidental. Para Cabaço (2007), a substituição do trabalho escravo pelo trabalho assalariado gerou, entre outras consequências, a movimentação da mão de obra africana dentro do continente, que se transformou numa fonte de rendimento para as economias coloniais. Hernández (2009) acrescenta que a então política colonial em Moçambique possuía uma estrutura de serviços voltados a responder às exportações e importações das colônias vizinhas da África do Sul e Rodézia, bem como ao fornecimento de mão de obra para a extração mineira e para a agricultura nesses países. Portanto, conclui o autor, centrou-se numa ação que buscou articular a acumulação do capital, a ação militar, a ocupação efetiva das terras e a utilização compulsiva da força de trabalho indígena, assentes numa dependência total do capital estrangeiro e das economias vizinhas.

É caso de dizer que, com todos os discursos aplicados na época com vistas à elevação do indígena a um grau de civilização aceitável mediante o trabalho, libertar o indígena do atraso que representava a sua cultura, que, como disse Cabaço (2007), para o colono nada mais era que um simples conjunto de usos e costumes, estava escondido e mascarado em formas medonhas de extração de excedentes que jamais foram capazes de responder à criação de um sistema agrícola e industrial autossuficiente, bem como ao desenvolvimento de infraestruturas capazes de alimentar um envolvimento no mundo capitalista congruente como se observava não só na Europa, mas também nos países vizinhos. Na realidade, o sistema fez com que mais se acentuasse a já existente

\footnotetext{
${ }^{6}$ Surge no código de trabalho indígena de 1899 e era aplicado a quem não pudesse ou não tivesse como pagar o imposto de palhota. Aqueles que eram apanhados para cumprir com o Xibalo eram requeridos para o trabalho em plantações agrícolas, edificação de caminhos e obras diversas, construções, empregos domésticos, entre outras atividades (HERNÁNDEZ, 2009).
} 
dependência econômica com o exterior, aprofundando ainda mais a pobreza da população indígena que caminhava debilitada diante do trabalho compulsório e do recrutamento para o trabalho nas minas da África do Sul em detrimento de um desenvolvimento agrícola local (HERNÁNDEZ, 2009).

Segundo Cabaço (2007), na tentativa de assimilar os nativos, o que na verdade ocorreu foi a implementação de uma política que acabou desqualificando oficialmente as culturas locais, agredindo crenças, práticas sociais, visão do mundo, sem nunca ter elevado os seres humanos a igualdades, pois, ainda que o indígena ganhasse o estatuto jurídico de cidadão, no plano social ele permanecia um membro subalterno que, no fim, via-se afastado das suas raízes, permanecendo dentro do mundo dos civilizados como a "casca inferior”, ou seja “o menos civilizado deles". Entretanto, para outros indígenas, num mundo em que o fator decisivo do progresso e de captação de riquezas era o trabalho, o colono soube retirar proveito ao extremo da exploração intensiva do trabalho, tornando-o base da economia do país. Isso fez ressurgir novas formas de adaptação da sua forma milenar de sobrevivência, da agricultura à mineira-industrial, para que se possibilitasse o desenvolvimento de novas maneiras de relacionamento entre a vida tradicional e o seu enquadramento no tão almejado sistema internacional de exploração capitalista.

\subsection{A Continuidade do Estado de Dependência}

O mito da superioridade foi um dos pilares da arquitetura colonial, que gerou relações de dominação/servidão nos diferentes atores sociais dos países africanos, especialmente em Moçambique, e que de certa forma é onde encontramos as razões e/ou as explicações para a condição de dependência a que, ainda hoje, estão sujeitas algumas nações africanas.

Moçambique, 40 anos depois da independência, ainda carrega os vestígios da dependência econômica e social gerados pelas políticas coloniais. Tais vestígios não só se confirmaram como seguem se consolidando, ainda que, segundo Marini (2000, p. 109) seria um equívoco comparar o sistema colonial à condição de dependência dos países, pois, para o autor, "a situação colonial não é igual à situação de dependência. Ainda que se dê uma continuidade entre ambas, não são homogêneas". No entanto, 
mesmo que aparentemente se mostrem diferentes, ambas partem de um conceito de superioridade que inibe o aparecimento das capacidades daqueles que serão considerados inferiores, em detrimento das ações e da aceitação de modelos que tampouco espelham suas culturas e seus objetivos.

Ora, com base na concepção de Marini (2000), o estado de dependência em Moçambique teria o seu início na década de 1980, quando a economia de Moçambique entrou em colapso e precisou da ajuda externa vinda do Ocidente. Para a obtenção dessa ajuda, as exigências feitas pelos doadores foram: a inevitável adesão à economia de mercado, ao Fundo Monetário Internacional (FMI) e ao Banco Mundial; que o país autorizasse a operação de organizações não-governamentais internacionais, como a CARE e a World Vision, que viriam cinco anos mais tarde a se multiplicar e a adoção de políticas de ajustamento estrutural, que consistiam num aparelho estatal mínimo, na desvalorização, desregulamentação e privatização (NIPASSA, 2009).

Em 1984, Moçambique torna-se membro do Fundo Monetário Internacional (FMI), mas o Programa de Ajustamento Estrutural exigido pelas agências doadoras teve seu início somente em 1987. A crise econômica dos anos 1980, a fraca capacidade da economia nacional de satisfazer às necessidades do mercado nacional e a incapacidade de o Estado moçambicano honrar os seus compromissos financeiros internacionais são aspectos citados como sendo os que motivaram as estruturas governamentais na altura a aceitarem tais intervenções políticas.

Para Macamo (2003), o programa de ajustamento estrutural nada mais foi do que uma reinvenção do Estado moçambicano como um espaço de intervenção externa. $\mathrm{O}$ autor salienta que o programa está aquém da correção de desiquilíbrios estruturais econômicos, sendo, acima de tudo, um projeto de normalização, afinal, estabelece normas de conduta que vão guiar o comportamento dos atores sociais em questão, fator fielmente mostrado acima por Castel-Branco (2011), exemplificando os aspectos que seriam levados em conta para a classificação das políticas econômicas. Por sua vez, para Macamo (2003), os programas de ajustamento estrutural trouxeram ao de cima a avaliação de políticas econômicas com prioridades nos números. Ainda que apreender o país em números fosse uma ideia infeliz, foi, porém, uma lição que Moçambique aprendeu escrupulosamente diante da forma como se apresenta, mostrando que melhorou bastante a sua capacidade de se resumir em números. No entanto, esse tipo de análise com base em números propicia que as instituições (FMI e o Banco Mundial) ajam com frieza em relação ao lado social das suas políticas, focando apenas no modelo, 
ignorando o comportamento do indivíduo que deveria ser levado em conta. Entretanto, continua o autor, as referidas análises feitas à base de números tomam Moçambique como um caso específico de "sucesso" das políticas implementadas no âmbito do ajustamento estrutural, pois, com elas, verifica-se a manutenção de taxas elevadas do crescimento do PIB e de taxas relativamente baixas na inflação. No entanto, como a análise de políticas vai além da apresentação de simples dados estatísticos, o que se observa são políticas econômicas implementadas na ótica dos doadores potenciais com total incapacidade de promover e organizar a produção alimentar para o mercado interno em grande escala e a preços baixos. Esse fator mal contribui para fornecer bens básicos de consumo e/ou alimentar os processos produtivos com insumos baratos e de qualidade, pouco contribui para a criação de novos empregos decentes e em larga escala, e acaba se mostrando ineficazes no sentido de reduzir a pobreza. Se o objetivo para a aderência de tais políticas era equilibrar a balança de pagamentos, este está longe de ser alcançado, sendo a principal conquista uma maior dependência do país ao auxílio externo (MACAMO, 2003; CASTEL-BRANCO, 2011).

Autores como Nipassa (2009) e Castel-Branco (2011) concordam que a indústria de caju é um bom exemplo para mostrar como a política de liberalização na comercialização da castanha em bruto acabou mal aplicada, ainda que o governo percebesse que ela apenas responderia aos interesses de um certo grupo restrito. A imposição feita pelos doadores teria sido o motivo pelo qual o governo teria se sujeitado a tal política. Castel-Branco (2011), que mostra em detalhes como vinha sendo aplicada a política do caju, diz que esperava-se que:

(...) os camponeses beneficiariam da liberalização, porque o preço de exportação da castanha em bruto iria subir e a percentagem do ganho comercial para os camponeses iria aumentar devido à crescente competição entre os comerciantes. Como resultado, os camponeses iriam investir na reabilitação e expansão das suas plantações de cajueiros e melhorar os seus meios de subsistência (CASTELBRANCO, 2011, p. 35).

Entretanto, o mesmo autor comenta adiante que a grande maioria dos produtores de caju, que por sinal são camponeses,

(...) seguem estratégias de trabalho diversificadas para melhorar as possibilidades de sobreviver, procurar e tirar vantagem de oportunidades de trabalho assalariado e reduzir riscos. Assim, mesmo que os camponeses tivessem capacidades adicionais para alocar à produção do caju, seria improvável que eles aumentassem a quantidade de trabalho, terra, esforço e investimento para se especializarem na produção de uma única cultura para um único 
mercado, sobre o qual não têm nenhum controle (CASTELBRANCO 2011, p. 36-37).

Portanto, sendo a estrutura do meio rural e sua forma de produção agrícola tampouco guiadas pelas lógicas do mercado, Castel-Branco (2011) afirma que os incentivos por via dos preços não seriam capazes, por si só, de conduzir o comportamento dos camponeses na sua decisão de investir nas suas plantações de cajueiros. Corroborando as afirmações de Castel-Branco (2011), Chambe (2012) por sua vez, também mostrou como muitas vezes as lógicas do mercado pouco funcionam nas decisões dos camponeses de investirem tempo de trabalho e dinheiro numa única cultura, mesmo contando com benefícios gerados pelo governo no acompanhamento das políticas em questão, como é o caso atual da política de repovoamento dos cajueiros, uma das culturas que foi altamente afetada pelas políticas de liberalização do mercado. Segundo a autora,

(...) o INCAJU ${ }^{7}$, através dos provedores de serviços, disponibiliza mudas para que os produtores experimentem e fiquem incentivados a aceitar esta nova tecnologia e, consequentemente, comprar as mudas melhoradas. As entrevistas efetuadas mostraram de que forma é recebido tal incentivo pelas populações: "temos tido apoio da Agricultura (INCAJU). Deram-nos 10 mudas para fazer a distribuição e convidar as populações a irem comprar a preços especiais. Mais só aceitam porque são oferecidas, comprar ninguém foi” (CHAMBE, 2012, p. 62).

Dentro dessa lógica, vale a pena resgatar uma frase de Marini (2000, pp. 118) que diz “(...) não é porque se cometeram abusos contra nações não industrializadas que estas se tornaram economicamente fracas, é porque eram fracas que abusou-se delas". Esta frase cabe para mostrar que, apesar dessas insuficiências na política, o FMI, por exemplo, continua a ter uma forte intervenção sobre o desenho das políticas macroeconômicas em Moçambique, devido à fragilidade e à fragmentação do governo como resultado da dependência da ajuda e consequente interferência de doadores (CASTEL-BRANCO, 2011). Assim, é viável concordar com Macamo (2003), quando diz que, da forma como as políticas vêm sendo desenhadas e implementadas, estas representam mais a continuação da política doméstica de contenção de risco dos países

\footnotetext{
${ }^{7}$ Instituto de Fomento do Caju. É um órgão de definição de políticas, estratégias de coordenação e supervisão das atividades realizadas em nível das diversas entidades executoras: produtores, setor privado, ONGs, etc., com o objetivo de promover o plantio de cajueiros, no mesmo tempo em que impulsiona a indústria do caju e seus derivados, ou seja, a revitalização do setor (CHAMBE, 2012).
} 
do centro para garantir a estabilidade e segurança destes, do que gerar o desenvolvimento em Moçambique, que continua com um acentuado atraso econômico.

Ora, se a cooperação com o Ocidente tem demostrado suas fragilidades e poucos resultados sociais visíveis aos olhos de uma parte da camada da sociedade moçambicana, recentemente, o que se assiste em Moçambique é um resgate e um aprofundamento das relações de cooperação com países dos BRICs, com destaque especial para o Brasil e a China. Estes países aparecem como esperança a outros modelos de cooperação e ajuda externa, afinal, usando as palavras de Roque e Alden (2012, p. 12), a "China aparece neste contexto quando gerações e gerações de moçambicanos tem testemunhado a cooperação com a Europa, mas continuam ainda à espera de ver os benefícios". Ainda que mostrem uma diversidade das áreas escolhidas para investimento, o setor agrícola vem sendo tomado como uma das áreas prioritárias de cooperação, sustentada pela tese de que a "agricultura era a abordagem eficaz para garantir a segurança alimentar, erradicação da pobreza e melhorar a vida das pessoas na África” (CHICHAVA, 2011, p. 373), considerando-se, por isso, necessário

O reforço da cooperação agrícola em áreas como a gestão da terra e dos recursos hídricos, desenvolvimento de infra-estruturas agrícolas, cultura, pecuária, aquicultura, segurança alimentar, intercambio e transferência de tecnologia agrícola aplicada, assistência técnica, fabricação de máquinas agrícolas e processamento de produtos agrícolas (CHICHAVA, 2011, p. 373).

Atuando nesse contexto, a China e o Brasil, especialmente, vêm fazendo grandes investimentos na área da agricultura e desenvolvimento rural. Chichava (2011) cita como investimentos chineses:

$\checkmark$ o estabelecimento de um centro de tecnologias agrárias,

$\checkmark$ o incremento na produção de arroz, que para tal vem ocupando enormes parcelas de terras, e

$\checkmark$ a concessão de crédito no valor de 50 milhões de dólares americanos para investimento em projetos agrícolas no Vale de Zambeze, entre outros.

Entretanto, de acordo com Chichava (2011) existem grandes preocupações com relação aos investimentos chineses na agricultura, especialmente nas questões ligadas à terra. Segundo o mesmo autor, os governos de Moçambique e da China assinaram um acordo para transformar o Vale de Zambeze numa "colônia" agrícola chinesa (com uma produção dirigida com exclusividade para o mercado chinês), sendo necessário para a sua concretização o envio de 3.000 chineses e estimando-se que o número destes 
chegaria a 10.000, sem contar com o investimento para a construção da ponte de Catembe ${ }^{8}$ e da barragem de Mpanda Nkhuwa ${ }^{9}$, que estariam dependentes da concessão de terras aos chineses.

Por sua vez, o Brasil direciona seus interesses mais na área dos biocombustíveis, onde, segundo Chichava (2011, p. 388), “o Brasil (...) espera transformar este país num grande produtor na África, ou seja, numa espécie de novo Brasil" ${ }^{10}$. Entretanto, a atuação do Brasil em Moçambique no setor agrícola é feita através da Empresa Brasileira de Pesquisa Agropecuária (Embrapa) que, em nível bilateral, além de direcionar apoios para o desenvolvimento da agricultura familiar das populações vizinhas cercadas pelo investimento mineiro que a companhia brasileira Vale do Rio Doce tem em Moatize, província de Tete (CHICHAVA, 2011), tem como foco fortalecer a capacidade do sistema de inovação tecnológica em áreas estratégicas vitais para o desenvolvimento rural em Moçambique e melhorar a competitividade do setor no que diz respeito à segurança alimentar e excedentes exportáveis (AVELHAM, 2014).

No plano multilateral de cooperação, Chichava (2011) destaca o projeto triangular entre o Brasil, a União Europeia e o governo de Moçambique, com o objetivo de desenvolver o setor de bioenergia - biocombustíveis e bioeletricidade. Segundo o autor, critica-se este projeto por não se perceberem benefícios para Moçambique, apenas para a Europa. Afinal, usa-se para tal enormes parcelas de terra agrícola no plantio de jatrofa e cana de açúcar em um país onde a fome cíclica é uma das questões mais preocupantes e merece atenção prioritária. Entretanto, o grande destaque vai para o ProSavana, (programa de desenvolvimento da agricultura das savanas tropicais no corredor de Nacala). É um projeto triangular entre o Brasil (Embrapa e ABC), Japão (JICA) e Moçambique (IIAM), mas que incentiva o investimento privado com o intuito de promover um sistema de produção sustentável que conduza à redução da pobreza (AVELHAM, 2014), bem como de desenvolver uma agricultura tropical no corredor de Nacala, região com características do cerrado brasileiro, podendo, por isso, ser a

\footnotetext{
${ }^{8}$ Ponte que liga Maputo (cidade capital de Moçambique) ao distrito que empresta seu nome à ponte. A travessia hoje é feita com praticidade através de um ferryboat.

${ }^{9}$ Extensão ou continuação da Barragem da Cahora-Bassa, ambas localizadas no Rio Zambeze, na provincial de Tete. Hoje a albufeira de Cahora-Bassa é a quarta maior da África, fornecendo produtos de eletricidade para Moçambique, África do Sul e Zimbabwé.

${ }^{10}$ Neste setor, o Brasil conta com um grande apoio do governo de Moçambique, que inclusive aprovou uma Política Nacional de Biocombustíveis.
} 
réplica em Moçambique do sucesso obtido no cerrado brasileiro também com investimento do Japão (CHICHAVA, 2011).

O ProSavana é um programa que gera debates em todos os níveis, pois possibilita a entrada de corporações transnacionais que, de certa forma, alienam a autonomia das famílias camponesas, destruindo seus sistemas típicos de produção, afinal, como observaram Clements e Fernandes (2013), as atividades da Embrapa são realizadas com modificações produtivas, com o objetivo de transformar a região em um território de monoculturas para exportação. Para Loureiro (2012), o modelo do agronegócio a ser transferido para Moçambique já foi visto por experiência do desenvolvimento do agronegócio brasileiro, tanto que pouco se considerou garantir a distribuição de renda e a preservação da terra e poder de quem dela necessita. Clements e Fernandes (2013) corroboram mostrando que a experiência brasileira gerou a dispersão dos produtores rurais e das comunidades indígenas, a criação de uma massa laboral empregada na cultura de soja e a migração de outros produtores para as cidades na procura de empregos. Assim, poderá se esperar, ainda, para Moçambique, o surgimento dos semterras e o aumento da insegurança alimentar, pois tampouco esse é um modelo capaz de inserir o tipo de agricultores, com raízes em aldeias, de pequena escala e que lutam pela sobrevivência do rural moçambicano. No máximo, prevê-se que a evolução do agronegócio em Moçambique apenas venha modificar o caráter da população rural, afetando a felicidade rural, para se embarcar numa lógica de agricultura capitalista, voltada para o mercado, onde cada vez mais serão necessárias políticas sociais que corrijam as falhas que a produção capitalista deixa por onde se instala.

Portanto, se pensarmos que o sentido de organização do quotidiano rural é guiado pela relação estabelecida com os espíritos antepassados, a exemplo do pahlar, rito tradicional que simboliza a apresentação das preocupações e/ou solicitação da aprovação dos mortos de algum ato, que pode ser no âmbito agrícola, na construção de grandes infraestruturas como pontes, barragens, etc. A prosperidade econômica e social das famílias e dos povoados é fortemente influenciada por tais relações. Assim, empresas transnacionais que vêm verticalizando as formas de produção agrícola, criando condições para que territórios nacionais cada vez mais se convertam em espaços de economias capitalistas internacionais, levam para as regiões rurais desafios para a supressão de diferenças nos relacionamentos e comunicação com as comunidades locais, onde conhecer as tradições locais e as relações sociais étnicas 
seriam as condições para entendimento e aprimoramento das relações com o meio rural moçambicano.

\subsection{Consequências da Dependência Externa no Meio Rural}

As populações de Inharrime e especialmente a dos povoados estudados passaram por diversas transformações sociais geradas pelos regimes de dominação colonial, com o ambicioso projeto de assimilação e trabalho forçado (xibalo), tratado na segunda parte deste capítulo. Por muitas vezes, devido à sua condição de assimilados, tais populações tiveram de renunciar a sua cultura para ter acesso às instituições de ensino e mesmo ao trabalho remunerado. Dos poucos casos encontrados de idosos ou pessoas acima dos 60 anos alfabetizados, ou que pelo menos tivessem, em algum momento de suas vidas, frequentado uma escola, disseram terem o feito nas missões católicas, e que a aceitação à condição de assimilado teria sido a única forma de conseguir melhorar sua condição de vida por via da alfabetização. Diz o relato oral, dos líderes comunitários entrevistados, que ainda que muitos não tivessem renunciado de fato à sua cultura, o projeto de assimilação afetou sobremaneira a forma de viver e encarar a vida da população. Afinal, o nativo assimilado, ainda que submetido à parte negativa que tal condição acarretava, encontrava "privilégios" de tratamento, pois podia encontrar trabalhos administrativos e empregos domésticos juntos às instituições coloniais, bem como na residência de alguns colonos.

$\mathrm{Na}$ tentativa de fugir ao xibalo, bem como na procura de um trabalho assalariado que o possibilitasse criar condições de vida melhoradas para si e sua família, a migração para as minas da África do Sul e para as grandes cidades nacionais foi a solução encontrada pela grande maioria dos homens de Inharrime. Não à toa que Inharrime se tornou reconhecida pela migração de homens no período colonial, fenômeno que foi exatamente motivado pela introdução dos impostos e do trabalho forçado submetido a homens e mulheres sob dominação. Nesse contexto, muitos homens migraram para as minas, pois encontravam no trabalho mineiro a garantia da isenção do xibalo do regime colonial. Sendo esta uma política que o sistema colonial adotou para a identificação da força de trabalho assalariada, mas que pudesse torná-la barata, isto é, com baixos salários e longas jornadas de trabalho, elementos típicos de acumulação capitalista de 
forma selvagem, o xibalo e o trabalho migratório alimentavam-se mutuamente, mostrando uma relação de reciprocidade.

Atualmente, a migração para o território das minas e grandes cidades transformou-se em cultura, ainda que motivada por outros interesses. Segundo o depoimento de alguns membros das famílias entrevistadas, não migrar pode representar fraqueza ou preguiça por parte do homem, fazendo com que este seja motivo de descriminação e/ou de ridicularização por parte de outros homens ou mulheres da comunidade. Afinal, na concepção desses homens, a experiência migratória permite que eles falem de trabalho com outros de igual maneira, identificando-os como tal homens. Nas palavras de um chefe do grupo familiar ${ }^{11}$ :

É importante para o homem sair daqui do mato e procurar trabalho lá fora. Se conseguir nas minas muito bem, porque lá é garantia de sucesso. Mas se não for lá, pelo menos tem que conseguir um trabalho para poder mandar dinheiro para casa, casar uma mulher e deixá-la bem aqui a cuidar das suas coisas e mesmo dos seus pais. Veja que aqui a nossa tradição são os homens a trabalhar fora mesmo antes de casar. Meu irmão foi o primeiro a conseguir ir para as minas. Eu fiquei aqui com a mulher dele. Queria casar, mas não tinha dinheiro, só trabalhava na machamba. Foi ai que meu irmão conseguiu me meter nas minas. Fui. Casei e ficaram aqui em casa as nossas mulheres a cuidar da casa e das crianças. Quando cresceram, também ensinamos que tem que procurar trabalho. Todos filhos aqui da casa trabalham fora. Saíram. Uns estão na África do Sul e outros estão em Maputo e Xaixai. Mas só um deles casou aqui e deixou a mulher aqui conosco. Os outros levaram as mulheres ou casaram lá mesmo e ficaram por lá. Mas trabalham.

Este é o depoimento de um chefe do grupo familiar de uma comunidade de Chireue, que atualmente conta com apenas cinco membros, dos quais quatro idosos, em consequência da migração dos membros restantes da família. Assim, mais do que responder a uma necessidade de busca pelo trabalho assalariado, o homem que migra sente, com o processo, uma obrigatoriedade masculina e a forma de expressar sua masculinidade.

Outra grande razão que gerou mudanças e consolidou a migração como fenômeno de mudança social foi a guerra civil que desolou grandemente os povoados estudados. De modo geral, Inharrime foi um dos distritos bastante afetados com a guerra, o que gerou uma movimentação massiva da população para os grandes centros urbanos ou regiões que se mostrassem mais seguras. A guerra também causou o isolamento de algumas áreas que quase nenhum crescimento ou desenvolvimento apresentam, mesmo

\footnotetext{
${ }^{11}$ Entrevista ocorrida no dia 21/12/14.
} 
com o retorno de parte da população às suas origens. Existem povoados que distam, para a escola de ensino primário e/ou centro de saúde mais próximo, cerca de $15 \mathrm{~km}$, sem nenhuma infraestrutura de serviços, lojas, sequer vias de acesso adequadas. Em resultado disso, os homens chegam à fase da adolescência e à sua fase adulta, mesmo que ainda na idade escolar, almejando sua emancipação como forma de procurarem empregos fora de sua região de origem, daí o outro incentivo para a migração masculina.

No fim das contas, o caminho para a migração possibilita buscar condições para melhorar o sustento das famílias, mediante o envio de dinheiro e bens materiais. É comum, nos meses de dezembro, verificarem-se movimentações fora dos padrões de mulheres em direção à vila sede de Inharrime, na expectativa de receberem encomendas mandadas pelos maridos trabalhadores na África do Sul. Por várias vezes, interpelei algumas, e em conversa, era frequente dizerem-me: "vou esperar o deliver ${ }^{12}$. Meu marido mandou lá dinheiro e alguma comida para passarmos as festas"; "eu vou porque soube que o deliver vai passar. Vai que também tenha algo para mim? Meu marido não irá vir este ano".

A condição de migrante ainda aufere ao homem um determinado status social dentro da comunidade, o que mostra que é um elemento de diferenciação social. O status vai estar de acordo com o tipo e tamanho da habitação que o migrante consegue construir. A qualidade da casa e seu tamanho funcionam como critérios de avaliação e como o grau de importância a ser-lhe atribuído na comunidade. Portanto, a preocupação sempre é por construção de moradias melhoradas, na base de blocos de cimento e, quanto mais cômodos tiver, melhor, pois facilmente verá a expressão de admiração e a relação de respeito pelos membros da sua comunidade. Bem diz uma canção que ouvi na festa do meu casamento em Inharrime e que frequentemente é cantada quando ocorrem cerimônias do gênero por membros que vivem fora da comunidade, mas que, no entanto, levam suas esposas para realizarem uma cerimônia de apresentação aos seus familiares que, por impossibilidade de varia ordem, não se fizeram presente no ato:

Construa sua casa (habitação) em casa (comunidade)

Afinal só mostras o respeito pelos teus, se a eles retornares

\footnotetext{
12 Nome que as mulheres (em Inharrime) dão ao carro que transporta os mineiros e/ou suas bagagens/encomendas vindas da África do Sul.
} 


\section{Que orgulho levas ao teus com tal atitude?}

E, assim é feita a história da grande maioria dos homens em Inharrime. A maioria das famílias entrevistadas tinha pelo menos um membro fora de casa, trabalhando ou em busca de emprego com melhores condições em relação às apresentadas no meio rural. Os poucos que lá permanecem, ou já passaram pelas minas, ou são os que, "beneficiados" com o projeto de assimilação, puderam estudar, capacitaram-se profissionalmente, melhoraram os níveis de formação e/ou melhoraram com formação complementar e conseguiram entre outros trabalhos, empregos nos serviços públicos que só nas grandes cidades poderiam encontrar. Como resultado, várias famílias apresentam elementos de até três gerações como migrantes, ao mesmo tempo que percebe-se que as comunidades, cada vez mais, são compostas por população idosa, mulheres e crianças.

\section{Conclusão}

O capítulo abordou a questão da dependência externa. Procurou mostrar em que contexto surgem seus conceitos e consequências. Contando que as contradições de ideias são os pontos chave para grandes debates, ainda que não explorados no mais alto nível, foi possível, de forma modesta, abordar em que contexto surge o subimperialismo e suas ligações com as questões da dependência externa a que nações estão sujeitas. Afinal, nações imperialistas, por vários anos, tiveram o monopólio sobre a ajuda externa disponibilizada aos países desfavorecidos. Estes encontram-se atualmente concorrendo com nações que outrora estiveram também dependentes daquelas.

Ao que se observou, ainda no período colonial, Moçambique teve a sua economia altamente dependente da dinâmica das economias da Rodézia e da África do Sul. Àquela altura, esses territórios eram colônias pertencentes à Inglaterra. Segundo Marini (2012), a hegemonia britânica foi marcada pela criação e consolidação do mercado mundial, mercado capitalista cujo objetivo central é de acumulação do capital de forma desmedida. 
Nos anos subsequentes à independência, Moçambique tentou enquadrar-se em outros ideais não capitalistas, como forma de buscar uma economia autossuficiente. Ainda assim, a condição de dependência permaneceu, ainda que neste período o que mais se observou foi a dependência externa, num contexto movido por ideais mais políticos do que econômicos. No entanto, as ineficácias de políticas e a guerra civil que, entre outros aspectos, mergulharam Moçambique num contexto de pobreza e vulnerabilidade, não ofereceu ao país outra solução senão submeter-se e sujeitar-se às políticas estabelecidas pelas instituições do Bretton Woods, como forma de mudar o cenário de sua economia e, consequentemente, as condições de vida da sua população, que padecia de fome.

Ainda que Moçambique observe hoje níveis elevados de crescimento econômico, tal como é demonstrado em diversos fóruns de pesquisa, o país continua sendo um dos países considerados mais pobres do mundo, ao mesmo tempo em que continua altamente dependente, a ponto de considerarem a condição de dependência como crônica para o país. Claro que, torna-se inevitável questionar em que medida tais políticas vêm favorecendo o conjunto daquilo que é o país, especialmente o seu lado social. Discussões em curso a respeito da temática levam a crer que o que vem acontecendo em resultado da dependência é o enriquecimento e acumulação capitalista de tais sociedades "modernas e civilizadas", o aparecimento de novas economias poderosas e cada vez mais projetos de desenvolvimento viáveis do ponto de vista econômico, mas que falham no aspecto mais desejável de melhorias da condição social dos povos.

E, assim, continua a crônica da dependência em Moçambique, com a entrada dessas novas economias, as consideradas "emergentes", que levam novas formas, promessas e condições de ajuda supostamente diferentes daquelas apresentadas pelo Ocidente. Ainda que o pano de fundo dessa nova forma de cooperação mostre-nos a transnacionalizaçao do capital, o entupimento do mercado com produtos importados provenientes de tais nações, de empresas estrangeiras transnacionais dos respectivos países, bem como a entrada de culturas, valores, hábitos e tradições desconhecidas da grande maioria da população, espera-se que a cooperação com estes países traga resultados positivos e mais esperançosos no âmbito social. 


\section{CAPÍTULO II - A ORIGEM E FORMAÇÃO DA FAMÍLIA}

\section{Introdução}

A família é o espaço indispensável para a garantia da sobrevivência, do desenvolvimento e da proteção integral dos seus componentes. Como local primordial de reprodução social, a família é a matriz dos vínculos sociais, biológicos, afetivos, bem como emocionais, afinal, é a célula básica da sociedade. É na família que se processa de forma inicial a construção da identidade. É nela, na família, que se dá a relação primária da criança com a mãe, com o pai, com os irmãos, construindo-se, no seu imaginário, as figuras parentais. É ainda espaço de produção, reprodução, consumo, distribuição e lucros. No entanto, cada família tem uma forma de organização, uma trajetória, um tamanho, traços, bem como ciclos de vida peculiares. A gênese é diferente para cada família e fortemente determinada pelas suas histórias, tradições e culturas distintas para cada região geográfica no mundo.

É dentro do contexto da família que definiu-se o objetivo do presente capítulo. Nele serão tratados os contextos universais da gênese da família, segundo o pensamento e fatos identificados na clássica obra de Engels (1987), para em seguida procurar perceber como seriam "enquadrados" os modelos apresentados no contexto das famílias africanas de um modo geral e das famílias moçambicanas, especialmente a comunidade chope do distrito de Inharrime, que correspondem o destaque do estudo apresentado. Aliada a essa temática, o capitulo procura mostrar os parâmetros do envolvimento da mulher no seio do seu agregado familiar, sua comunidade, assim como os locais e as condições em que ela exerce o poder e autonomia. 


\subsection{A Origem da Família}

De acordo com a obra "A origem da família, da propriedade privada e do Estado", de Engels (1987), pode-se constatar que a pré-história da humanidade é conhecida inicialmente pelos estudos de Morgan como o primeiro que, por conhecimento de causa, dividiu e ordenou os estados da civilização humana em três dimensões: o estado selvagem, a barbárie e a civilização. Destas três dimensões, Morgan se ocupou com a descrição do estado selvagem e da barbárie, ficando o estado da civilização por conta de Engels.

Da descrição apresentada por Morgan, cada estado da civilização humana era, por sua vez, subdividido em três fases distintas: a fase inferior, a fase média e a fase superior. No estado selvagem, a fase inferior é aquela em que os homens permaneciam em bosques tropicais ou subtropicais, tinham como alimentos apenas os frutos, nozes e raízes, sendo que o único marco dessa fase foi o desenvolvimento da linguagem articulada. Na fase média, observa-se uma melhora na alimentação do homem com a introdução de peixes, crustáceos e moluscos em razão da descoberta do fogo, que também foi o facilitador de um povoamento maior em novos lugares. A fase superior é marcada com a invenção do arco e flecha, que torna a caça uma ocupação normal e costumeira. Em simultâneo, aparece o desenvolvimento da cerâmica.

A barbárie começa, na sua fase inferior, com a introdução da cerâmica, desenvolvida no último estágio da fase média. Neste período, já começa a fazer-se sentir a diferença de condições entre os dois continentes (Ocidental e Oriental) através da atividade de domesticação e criação de animais e do cultivo de plantas. O continente Oriental já tinha quase todos os animais domesticáveis e todos cereais próprios para o cultivo, enquanto que o continente Ocidental apenas tinha um animal domesticável, a lhama, e o milho como único cereal cultivável. Essas condições diferenciadas fazem com que as populações de cada hemisfério se desenvolvam de maneira particular e diferenciada. Na fase média da barbárie, no leste, inicia-se a domesticação de animais e o oeste se moderniza com o cultivo de hortaliças por meio de irrigação e emprego de tijolo cru (secado ao sol) e da pedra nas construções. A fase superior se caracteriza com a fundição do minério de ferro, com a introdução da escrita alfabética e com um acentuado progresso da produção. 
De acordo com Engels (1987), no estado selvagem, há uma apropriação dos produtos da natureza prontos para serem utilizados, estando as produções artificiais do homem destinadas a facilitar essa apropriação. Na barbárie, são introduzidas a criação do gado e a agricultura, o que mostra que se aprende a incrementar a produção da natureza por meio do trabalho humano. Na civilização, há uma continuação do aprendizado na elaboração de produtos naturais, além do aparecimento da indústria propriamente dita e da arte.

Portanto, Engels (1987) dizia que a família se desenvolve acompanhando a dinâmica do desenvolvimento da sociedade. Nessa lógica, considera-se que a família seja um elemento ativo, na medida em que nunca permanece estacionária, pois, acompanhando esse desenvolvimento da civilização humana, passa de uma forma inferior a uma forma superior, à medida que a sociedade evolui de um grau mais baixo para outro mais elevado. Isso vai se diferenciar dos sistemas de parentescos por estes se apresentarem passivos, pois só depois de longos intervalos é que registram os progressos feitos pela família e não sofrem uma modificação radical, a não ser quando a família já tenha se modificado radicalmente.

No processo de evolução da família, diz Engels (1987) que a conclusão de Morgan é de que existiu uma época primitiva em que imperava no seio da tribo o comércio sexual promíscuo, em que cada mulher pertencia igualmente a todos os homens e cada homem a todas as mulheres. Desse estado primitivo de promiscuidade, formaram-se a família consanguínea, a punaluana, a sindiásmica e a monogâmica, descritas segundo Engles (1987).

\section{A família consanguínea}

Esta representa a primeira etapa da família. Nelas, os cônjuges formavam-se por gerações: todos os avôs e avós, no limite da família, são marido e mulher entre si e formam a primeira geração. $\mathrm{O}$ mesmo sucede com seus filhos, que serão a segunda geração e, por conseguinte, com os filhos dos filhos daqueles, que é a terceira geração.

\section{A família punaluana}

Nela, exclui-se pais, filhos e, mais tarde, irmãos das relações sexuais recíprocas. Esse progresso, para Morgan, foi uma forma de mostrar como atua o princípio da seleção natural. Nesta etapa da família, os filhos das irmãs da minha mãe são também filhos desta; os filhos dos irmãos do meu pai são também filhos deste. Aqui, exclui-se os filhos dos irmãos da minha mãe e os filhos das irmãs do meu pai, que serão somente 
sobrinhos deste e todos eles são apenas meus primos. Nessa lógica, os maridos das irmãs da minha mãe e as mulheres dos irmãos do meu pai são também maridos da minha mãe e mulheres do meu pai, respectivamente. Seguindo este princípio, a paternidade de uma criança será algo desconhecido, mas, com certeza, sabe-se quem é a mãe. Por isso, a descendência é pelo lado materno, o que leva a ser reconhecida somente a linhagem feminina.

\section{A família sindiásmica}

É gerada de uniões aos pares de duração mais ou menos longa. Nestas famílias, um homem passa a viver com uma mulher, de maneira tal que a poligamia e a infidelidade ocasional continuam a ser um direito dos homens, em que, em contrapartida, exige-se a mais rigorosa fidelidade das mulheres enquanto dure a vida em comum. O adultério da mulher será, assim, cruelmente castigado. Apesar dessa exigência de fidelidade, os filhos continuam pertencentes exclusivamente à mãe e passa a haver um reconhecimento exclusivo de uma mãe própria. Isso mostra que as mulheres continuam sendo a força dentro dos clãs e a categoria de mãe é vista com grande apreço.

A família sindiásmica aparece no limite entre o estado selvagem e a barbárie. Durante este período, sabe-se que também se desenvolveu a propriedade privada dos rebanhos, utensílios de metais, os objetos de luxo, bem como surgiu o "gado humano" - os escravos. Essas riquezas seriam então convertidas em propriedades particulares das famílias. Se era, então, considerada uma forma de matrimônio mais sólida, em que havia uma estrutura familiar composta por uma verdadeira mãe, junto a esta havia um posto de verdadeiro pai. Na divisão de trabalho, cabia a este, o homem, procurar a alimentação e os instrumentos de trabalho. Logo, era, por direito, o proprietário dos respectivos instrumentos. Entretanto, sendo a descendência dos filhos por via materna, os filhos não podiam herdar a herança do pai. Portanto, em situação de morte dos proprietários, esses instrumentos passavam, em primeiro lugar, aos seus irmãos e irmãs e aos filhos destes ou aos descendentes das irmãs de sua mãe. Na sequência, à medida que a riqueza ia aumentando, o estatuto e a importância do homem na família ia se tornando superior ao da mulher, instigando a ideia e a necessidade de valer-se dessa vantagem para modificar, em proveito dos seus filhos, a ordem da herança estabelecida. Para isso, teriam de abolir o direito materno, estabelecendo-se, assim, a filiação masculina e o direito hereditário paterno. Surge, daí, o patriarcado.

No processo de evolução da unidade familiar, o homem apoderou-se ainda da direção da casa, degradando o papel da mulher, que passa a ser servidora e convertida 
em escrava. A mulher passa a ser, simplesmente, um instrumento de reprodução. A família passa a ter uma organização de certo número de indivíduos livres e um outro número de indivíduos não livres, submetidos ao poder paterno do seu chefe. Portanto, na família sindiásmica, além de se incorporar os escravos, o domínio passa a ser paterno.

Foi nessa ótica da família patriarcal que a expressão "família" passa a representar herança como novo organismo social, cujo chefe mantinha sob seu domínio a mulher, os filhos e certo número de escravos, com o direito de vida e morte sobre eles. Nessa descrição, Marx acrescenta à família moderna a servidão. Portanto, esta forma de família assinala a passagem do matrimônio sindiásmico à monogamia.

\section{A família monogâmica}

Este tipo de família surge na transição entre a fase média e a fase superior da barbárie. O predomínio, aqui, é dado ao homem e este vai formar a sua família com a finalidade de procriar filhos (herdeiros) cuja paternidade seja indiscutível. A diferença da monogamia em relação ao matrimônio sindiásmico é a solidez maior dos laços conjugais, que já não podem ser rompidos por vontade de qualquer das partes. Só o homem pode romper e repudiar sua mulher e ao homem é ainda lhe dado o direito à infidelidade conjugal.

Entre vários aspectos que caracterizaram a monogamia, dois aspectos valem a pena serem mencionados com relação à família monogâmica. Primeiro, na monogamia, as famílias não eram formadas ou geradas por amor sexual individual, baseadas em condições naturais, mas sim, imperavam condições econômicas que permitiam o triunfo da propriedade privada sobre a propriedade comum primitiva. Segundo, a monogamia não aparece na história como uma reconciliação entre o homem e a mulher, e tampouco representa uma forma mais elevada do matrimônio. Pelo contrário, surge sobre a forma de escravidão de um sexo sobre o outro, proclamando um conflito entre os sexos outrora ignorado.

Portanto, Engels (1987) descreve três formas principais de matrimônio correspondentes aos três estágios fundamentais da evolução humana, que foram: o estágio selvagem, com o matrimônio por grupos, a barbárie, com o matrimônio sindiásmico e a civilização, com a família monogâmica. A condição monogâmica tampouco indicou a fidelidade dentro do casamento, pelo contrário, veio com diversos componentes, entre eles, o adultério conferido aos homens e a prostituição conferida às mulheres. A própria monogamia surge da concentração da riqueza nas mãos do homem 
e do desejo de transmiti-las por herança. Daí a necessidade de uniões mais sólidas, em que era fundamental a fidelidade da mulher. Por isso que nessa sucessão de formas de matrimonio assiste-se a retirada gradual da liberdade sexual da mulher, característica do matrimônio por grupo.

\subsection{A Perspectiva Africana de Família}

Para um contexto africano, os estudos centrados na origem da família tomam como referência as leituras eurocêntricas, sendo que muito pouco é estudado tendo como o ponto de partida o lugar africano. Nessa perspectiva, o que mais se observa são interpretações de cultura e dados africanos por meio de enunciados ocidentais, sem desafiar nem as teorias recebidas, nem os enquadramentos conceituais (ADESINA, 2012). Entretanto, a colonização tardia da África interrompeu um processo que ainda se encontra em curso em pontos focalizados, o que mostra, segundo Adesina (2012), a necessidade de um recuo a períodos anteriores ao colonialismo tardio, que mostra como as influências indo-europeias remodelaram profundamente muitas sociedades africanas.

Adesina (2012) apropria-se de dois estudos realizados por duas acadêmicas africanas para teorizar a matrifocalidade partindo da África, que rompem ideias préconcebidas da epistemologia na compreensão sociológica das relações de gênero, bem como o próprio significado de gênero. Inicia mostrando que o conceito de matrifocalidade ou família matrifocal é popularmente usado para designar agregados familiares chefiados por mulheres, em que, na maior parte dos casos, ocorre por ausência do pai ou do esposo. Segundo Adesina (2012), Parkim (1977) define a família matrifocal como aquela em que os adultos do sexo masculino se ausentam da casa por longos períodos de tempo por motivos de trabalho ou outras razões, mas, vale lembrar que o primeiro estudioso que teria ligado esta estrutura familiar, apropriada e ligada ao conceito matrifocal, foi Raymond Smith (1996).

Seu ponto de partida para mostrar o que os trabalhos das duas acadêmicas africanas trazem de diferente está centrado no estudo de Smith (1956) sobre os agregados familiares de "classes mais baixas" nas Guianas. Adesina (2012) mostra que, na visão deste autor, nas estruturas matricêntricas, durante os períodos iniciais de 
crescimento da criança, a mulher é dependente do esposo num processo de rígida divisão de trabalho: o homem tem uma ação limitada ou nenhuma no desenvolvimento da criança, mas apoia a mulher que se encontra preocupada com a educação dessa mesma criança.

À medida que as crianças crescem... [a] mulher vai sendo gradualmente libertada do trabalho de cuidar delas com maior permanência, e quando as crianças começam a auferir alguns ganhos passam a contribuir para as despesas diárias do agregado familiar. É nesta fase que se começa a notar com maior clareza o padrão subjacente das relações dentro do grupo doméstico; a mulher passa do centro em redor do qual se desenvolvem os laços afetivos, para se tornar agora, em conjunto com os seus filhos, no centro de uma coligação económica e de tomada de decisões. Este crescimento da qualidade 'matrifocal' ocorre, quer o esposo-pai esteja presente ou não (ADESINA 2012, p. 197 apud SMITH 1996, p. 42).

Adesina (2012) mostra que Smith percebia um parentesco bilateral das famílias matrifocais, em que a matrifocalidade aparece ligada à divisão de trabalho, seja no nível doméstico ou não, mas que era uma estrutura ligada aos agregados familiares de classes mais baixas, nas quais se exclui a mulher das atividades econômicas extra-domésticas. Nesta lógica, a matrifocalidade diminui na medida em que se desloca para o sentido ascendente dentro das estruturas de classes da sociedade. Portanto, para Adesina (2012), Smith não considera a matrifocalidade um estado da sociedade e tampouco caracteriza os sistemas de parentesco das sociedades. Aparece sim, como resultado de um status econômico baixo e de exclusão jurídica da mulher, manifestando-se sob três domínios: relações domésticas, laços familiares e estratificação social.

Ora, Adesina (2012) procura, então, mostrar um outro ponto de vista da matrifocalidade como conceitos organizadores, com base nos trabalhos das africanas Ifi Amadiume e Oyeronke Oyewumi, nas comunidades de Nnobi (da Nigéria Oriental) e Yorùbá respectivamente. Por meio desses trabalhos, Adesina (2012) conclui que as famílias matrifocais não o são por causa da sua baixa condição econômica, de pobreza, de ausência de homens, da distribuição de tarefas domésticas com base na divisão de gênero ou de exclusão econômica da mulher. Elas assim o são por serem estruturalmente matricêntricas.

De acordo com Adesina (2012), a ideia linear de evolução humana com primazia à família monogâmica e patriarcal não deve ser generalizada para contextos africanos, pois, em muitas sociedades africanas, mais que a patrifocalidade, a norma é a matrifocalidade. Entretanto, a autora considera que não deve ser observado o 
matriarcado como um sistema totalitário, e sim como um sistema estrutural em justaposição a outro sistema numa estrutura social. A autora sustenta a posição de que deve-se dar mais atenção aos dados etnográficos, nos quais se revela que a unidade matricêntrica é uma unidade não só de produção autônoma, mas também uma unidade ideológica que gera códigos normais distintos.

É nessa lógica que, segundo Adesina (2012), quando estudava a comunidade Nnobi, Amadiume (1987) mostrou que as dinâmicas desta comunidade têm uma forte inclinação para a dualidade sexual, mas que, ainda assim, a comunidade era predominantemente matricêntrica, desde a sua origem até ao agregado familiar, no modo de organizar da produção econômica até o sistema de governação. Essa dualidade sexual na origem e organização da comunidade mostra que homens e mulheres detêm dos mesmos direitos e prestígio, e do princípio da maternidade compartilhada ainda se verifica:

A instituição de "primeiras filhas" significa que tanto elas como os homens podem ter várias "esposas" (...) as primeiras filhas, mulheres estéreis e viúvas ricas, esposas de homens ricos e mulheres camponesas ou comerciantes bem sucedidas tomam esposas para si, (...) "esposos femininos". As relações sexuais com o intuito de procriação ocorrem entre a esposa e parentes escolhidos do "esposo feminino", sendo as crianças daí resultantes, reconhecidas como filhos do "esposo feminino" (ADESINA, 2012, p. 200).

Esta é a lógica da comunidade, que mostra um agregado familiar composto por todos componentes gerados dentro de um matrimônio com todas as suas particularidades. Segundo Adesina (2012), os papeis da dualidade sexual na comunidade Nnobi aparece também refletido em termos jurídicos:

(...) as linhagens masculina e feminina desempenham papeis jurídicos distintos. A organização das filhas patrilineares (umu okpu) é formal, abrangendo filhas casadas e solteiras, sendo a liderança baseada na senioridade. A filha mais velha dirige o umu okpu, independentemente do seu estatuto conjugal (ADESINA, 2012, p. 200).

De acordo com Adesina (2012), os dados de Amadiume (1987) sugerem que o que mais entra em questão é a idade e menos a condição de gênero de quem detém o poder. Esse aspecto, voltado ao estatuto de senioridade baseado em relações consanguíneas dentro da matrifocalidade, foi verificado também no trabalho de Oyewumi (1997), junto à comunidade Yorùbá.

Segundo Adesina (2012), Oyewumi mostrou nos seus dados etnográficos que, na comunidade Yorùbá, homens e mulheres não são classificados segundo distinções 
anatômicas, tampouco havia a designação mulheres na definição estrita de gênero. Tanto que, observa a autora, Oyewumi (1997) disse que, antes da colonização pelo ocidente, os princípios de gênero não faziam parte dos princípios organizativos da sociedade Yorùbá, pelo que o princípio pautava-se pela senioridade definida pela idade relativa, sendo que as designações "masculino" e "feminino" são de difícil tradução linguística e não carregam consigo privilégios ou desvantagens sociais. Portanto, um superior é assim designado independente da forma do corpo, e a condição de senioridade é relacional e situacional, pois ninguém ocupará para sempre uma posição sênior ou júnior.

Segundo Adesina (2012), na sociedade Yorùbá mostrada por Oyewumi, o princípio da maternidade informa o quadro ideológico da ordem e das relações sociais, nas quais até as mulheres, como educadoras dos filhos, podem adquirir poderes sagrados/mitos. Outro aspecto de relevância tomado em conta por Adesina (2012) é o parentesco uterino definido à volta da maternidade, ainda assim, a autora diz que essas sociedades são melhor compreendidas numa espécie de linhagem dupla.

Para Adesina (2012), Oyewumi mostra em seu trabalho que, fora da esfera doméstica, as atividades econômicas das mulheres são de caráter independente e autônomo, estando estas no domínio dos mercados e do comércio a longa distância, bem como verifica-se a presença de mulheres na esfera da administração pública:

(...) mais uma vez, os dados de Oyewumi sugerem a presença de mulheres na esfera política até ao nível do Alâfin Oyo - o cargo de líder político do Reino de Oyo. Vários funcionários públicos de escalão político mais baixo (Baálè) eram também mulheres. A história política recente dos Ibadan, um segmento dos Yorùbá, sugere que as mulheres ocupavam ativamente o cargo político sênior de Iyálóde. A história do Reino de Oyo mostra a existência de ilárí anafemininos e ana- masculinos, funcionários políticos que também desempenhavam as funções de guarda-costas do Alâfin (ADESINA, 2012, p. 202).

Esses trabalhos mostrados por Adesina (2012), além de trazerem ideias direcionadas a uma “(...) mudança epistêmica na nossa compreensão sobre a ideia global de gênero" (ADESINA 2012, p. 202) mostram ainda que, na África, o processo de evolução humana foi interrompido com a colonização, sendo às sociedades impostos princípios e valores tidos como "ideais para a civilização" das comunidades vistas como atrasadas ou o "outro" dentro de um padrão de entendimento voltado para o Ocidente. 


\subsection{A Família em Moçambique}

A nação moçambicana encontra-se ainda em construção, depois de um longo processo de colonização e guerra civil que ocorreu logo depois da independência nacional. Entretanto, tal como a África no geral, Moçambique é de uma diversidade cultural, rica em valores tradicionais que, apesar de considerados "retrógrados", persistem nos dias atuais, o que dão ao indivíduo a sua identidade como pertencente à determinada comunidade e, assim, expressam sua moçambicanidade e, especialmente à mulher, possibilita uma gama de possibilidades de atuação, mostrando sua participação tanto na esfera pública como na tradicional de poder.

Como muitos dos povos africanos, os povos de Moçambique têm as suas origens no grande grupo dos povos Bantu que povoa quase toda a África ao sul do Saara. O nome Bantu significa gente ou povo e não é nome de raça ou tribo. É apenas o nome de grupos de línguas dos diferentes grupos étnicos da África, incluindo Moçambique. Dentre os vários grupos étnicos que povoam o país ao norte do rio Zambeze, encontram-se os Swahilis, Macua-lomwes (a mais numerosa etnia de Moçambique e com predominância matrilinear) Ajauas, Maravis e Macondes. Ao sul de Zambeze encontram-se os Chonas, Angonis, Tsongas, Bitongas e Chopes, com predominância patrilinear, sendo a etnia chope a que será abordada neste trabalho. Entretanto, há que se destacar, juntamente a estes grupos, a componente do povo moçambicano constituída por asiáticos, precisamente os indianos trazidos pelos contatos comerciais com o país, iniciados bem antes da colonização europeia.

Para Garcia (2001), tal como na grande maioria das sociedades africanas, as particularidades da sociedade moçambicana são mostradas na sua percepção da vida. No geral, entendem a vida como um processo dinâmico, onde nele devem ser levados em conta os vivos, os mortos, as coisas inanimadas e os elementos da Natureza. Uma das características comuns dentro dos grupos étnicos, como de um modo geral acontece nas sociedades africanas é a sua concentração em família extensa, o que fortalece a coesão do grupo. Essas famílias possuem basicamente um caráter comunitário no que tange às diferentes frentes, religiosa, econômica, bem como de simples existência. As atividades dos indivíduos visam ao interesse coletivo, sendo que seus objetivos são subordinados aos objetivos gerais, tal como observou Miguel Garcia (2001). 
Em outros contextos, Pinho (2011), em suas leituras sobre a articulação dos sistemas de parentesco, mostrou posições que indicavam que, na África, a função social do parentesco pouco se importava com vínculos afetivos e biológicos resultantes da descendência ou do casamento. Afinal, segundo o autor, o exercício prático da vida social torna o parentesco um ato de reconhecimento da relação entre pai e filho. Neste caso, o casamento é o guia das relações sociais que confere dinamismo à sociedade, entendido o dinamismo como reprodução de uma ordem dada dentro de um contexto determinado, contexto este que foi posto em pauta com as alterações que a ocupação colonial, as missões e o dinheiro trouxeram às sociedades africanas. Segundo Pinho (2011), enquanto nas sociedades ocidentais, tal como descritas por Engels (1987), o matrimônio ocorre sob a égide do amor romântico e do individualismo, nas sociedades africanas o matrimônio envolve todo o grupo social, pois emerge da articulação entre grupos distintos e visam à reprodução do grupo (produzir crianças), o que torna a instituição do casamento o meio pelo qual uma criança adquire uma situação legítima na sociedade, como mostra Pinho (2011) com o decurso que deu na sua revisão de literatura.

Certamente, essas características peculiares das sociedades vão colocar homens e mulheres em posições distintas e com papeis diferenciados. No contexto familiar, a posição da mulher em Moçambique é bastante diferenciada, e é definida a partir da caracterização da cultura do seu grupo étnico. Os mitos, as verdades, os tabus ou os hábitos irão determinar o domínio de atuação da mulher no contexto familiar, bem como o tipo de sociedade, entre matrilinear ou patrilinear, que também são fatores que colocam em questão a posição e o papel da mulher dentro do seu grupo.

2.3.1. As comunidades com predominância matrilinear: o exemplo dos Macua-lomwe

No caso das comunidades matrilineares, que se encontram no norte do país, a mais abrangente é o grupo linguístico Macua-Lomwe, localizado, em grande maioria, na província de Nampula. Nessas comunidades, a arte de sedução é um elemento específico de domínio feminino, bem como as relações sexuais e afetivas, que emergem como um espaço de poder controlado pelas mulheres. Os Macua-Lomwe correspondem a um povo caracterizado pelos seus ritos de iniciação típicos das regiões centro e norte 
do país. Os ritos de iniciação têm por objetivo integrar o indivíduo numa ordem simbólica e religiosa específica. Constituem o apogeu da educação tradicional, sendo o momento em que se ensina a moral com respeito aos outros e aos mais velhos, ou seja, as crianças aprendem tudo sobre a vida. Numa discussão sobre a importância e objetivo dos ritos de iniciação feita no trabalho de Osório e Macuácua (2013), pode-se extrair, entre várias descritas pelas autoras, a importância dos ritos contendo a:

(...) função de padronização de comportamentos e valores com o fim de reforçar a pertença ao grupo. Os ritos ordenam, classificam e orientam, salvam do caos e da desordem, tendo assim um papel de harmonização (...) o iniciado fica curado da infância e prepara- se para viver e pensar em função de um novo estatuto que o qualifica como adulto (...) a iniciação é um rito de formação que vai diferenciar os participantes ou o círculo de neófitos dos de fora, daqueles exatamente não-iniciados (OSÓRIO E MACUÁCA, 2013, pp. 7172).

Essa importância dos ritos de iniciação para os Macua-Lomwe, para além de representar a sua identidade como grupo, faz com que cada membro iniciado se sinta superior e purificado com sua passagem pelos ritos. Esse fato Chiziane (2002, p. 3940) mostra com a seguinte passagem, brevemente resumida:

- Frequentaste os ritos de Iniciação? (...)

- Não (...). - Frequentei outras escolas (...)

- Refiro-me as escolas de amor e vida (...)

- O que aprendem então nesses ritos, que vos faz sentir mais mulheres do que nos?

- Muitas coisas: de amor, de sedução, de maternidade, de sociedade (...). Como queres ser feliz no lar se não recebeste as lições básicas de amor e sexo. Na iniciação aprendes a conhecer o tesouro que tens dentro de ti (...). aprendes a conhecer a anatomia e todos os astros que gravitam dentro de ti. Aprendes o ritmo dos corações que palpitam dentro de ti (...).

- Sem eles (...) não te podes casar, ninguém te aceita. Se te aceitar, logo depois te abandona. Não podes participar num funeral, muito menos aproximar-te de um cadáver porque não tens maturidade. Nem podes assistir a um parto. Não podes tratar de assuntos de casamento porque és impura.

Existem ainda, dentro destas matrilinhagens, os clãs (n'loko) e linhagens (nihimo) chefiados por homens, como também as linhagens "rainhas" designada de awiyamwene ou apwiyamwene nihimo, confiadas para a resolução de problemas da comunidade, bem como na preservação da tradição. A apwiyamwene é a irmã mais velha do chefe ou régulo. É considerada uma autoridade mítica na qual se buscam conselhos e opiniões, que são inquestionavelmente seguidas. Se apresenta como uma autoridade dentro do sistema. As apwiyamwene, na qualidade de conselheiras, tomam conhecimento de tudo 
que acontece na linhagem e exercem influência na decisão do chefe da linhagem, pois, somente depois de ouvidas, é que o chefe da linhagem toma uma decisão. A desobediência a este grupo pode, acredita-se, atrair para si todas as iras dos antepassados com consequências mesmo depois da morte (GARCIA, 2001; TVEDTEN, PAULO e TUOMINEN, 2009).

Nessas matrilinhagens, a influência dá-se pelo lado da mãe, através dos seus membros masculinos (pai ou irmão mais velho da mãe). Originalmente, o padrão de residência era uxorilocal, o que implicava ao homem mudar-se para a casa da mulher (TVEDTEN, PAULO e TUOMINEN, 2009). Segundo Negrão (2000), além da residência uxorilocal, a matrilinhagem também permite o casamento patrilocal, em que a mulher se muda para a aldeia do marido, forma esta que veio a crescer significativamente durante o século $\mathrm{XX}$. Na forma de casamento matrilocal (a residência uxorilocal), Negrão (2000) acrescenta que a mulher, ainda que possua o direito de copropriedade, está sob domínio de um tio materno sobre quem recai a responsabilidade da matrilinhagem e transmitida, na sua morte para o filho mais velho da filha primogênita da sua mãe. No caso de morte da mulher, uma outra, com a mesma designação clânica, a substitui, assumindo o estatuto, o marido e as terras da matrilinhagem.

Os Macuas-Lomwe tiveram uma grande influência dos povos árabes, que trouxeram a religião muçulmana, que veio a se contrariar com a tradição matrilinear desses povos. Os muçulmanos privilegiam a posição dos homens e a linha masculina em assuntos econômicos, familiares e religiosos. Reforçam ainda a tradição de poligamia, sendo o número de esposas uma expressão de valor mundano, bem como piedoso. À primeira mulher cabia-lhe mais direitos e obrigações para com seu marido, ainda que, pelo Corão, o homem deva tratar todas esposas com o mesmo respeito (TVEDTEN, PAULO e TUOMINEN, 2009). Essa tradição muçulmana chegou a se enraizar nas estruturas do poder local (as autoridades tradicionais), tendo de coabitar com a tradição da matrilinhagem, exemplo mostrado quando se observam autoridades femininas que promovem a ligação entre a família e o espaço mais amplo dos antepassados e asseguram a reprodução da linhagem (MENESES, 2008).

A chegada dos portugueses veio reforçar ainda mais a posição dos homens dentro dessas comunidades. Com o sistema de trabalho forçado (xibalo), nas matrilinhagens, as mulheres acabaram direcionando-se apenas às atividades agrícolas de subsistência, à produção de culturas de rendimento que garantissem o pagamento de impostos 
coloniais e à gerência do lar, enquanto que o homem trabalhava para os agricultores portugueses, para as indústrias nas áreas urbanas, onde recebiam em dinheiro ou espécie, fortalecendo sua base econômica para a sua posição sócio-cultural junto à comunidade (TVEDTEN, PAULO e TUOMINEN, 2009). Da mesma forma, alguns homens preferiram investir seus esforços na ocupação de "terras dispersas", onde apenas as dedicavam para culturas de rendimento, deixando as terras da matrilinhagem para as atividades agrícolas de subsistência, ou por outra opção, deslocava-se com sua esposa para as "terras dispersas", reduzindo ao mínimo o poder de decisão do tio materno e da própria mulher (NEGRÃO, 2000). Neste último caso, acrescenta o autor, a herança do homem passa a ser transmitida para seu filho primogênito, que ainda assim continua subordinado ao seu tio materno com quem tem a mesma designação clânica. Assim, essa dupla subordinação condicionou o surgimento do casamento entre primos cruzados, pois o homem, na qualidade de pai dos seus filhos varões e na qualidade de tio das suas sobrinhas, passa a dar preferência ao casamento entre eles.

Outro aspecto de relevância verificado com a chegada dos portugueses foi a legitimidade dos chefes locais (agora autoridades tradicionais) promovida pelo governo colonial. Mediante a sua integração no sistema colonial português do poder local, esse fato reforçou a perda de visibilidade da mulher na esfera pública de poder (MENESES, 2008). Na verdade, nada mais foi que uma maneira de fragilizar a cultura e eliminá-la com determinadas práticas que, por conseguinte, poderiam interferir negativamente no seu projeto de ocupação. Portanto, houve aqui uma tentativa de fragilização da cultura, bem como a ruptura da tradição, tal como observa Garcia (2001), ao afirmar que o projeto do poder português se percebeu da necessidade de dividir as forças tradicionais, pois não se mostravam viáveis para a manutenção da liderança da administração portuguesa.

\subsubsection{As comunidades de predominância patrilinear}

As patrilinhagens predominam a maior parte do território moçambicano. Sobre estas sociedades pouco se encontra de estudos que focalizem no contexto do processo de evolução da família, que culmina com a família monogâmica e patriarcal, apesar de Junod (1996) considerar que, em determinadas tribos do sul do país, ainda possuam 
resquícios dos diferentes sistemas de parentescos tratados por Engels (1987). Na concepção de Junod (1996), as comunidades do sul de Moçambique atingiram, em algum momento, o quarto estágio, correspondente à família patriarcal favorecida pelo desenvolvimento da propriedade privada. Junod (1996) acrescenta que as famílias se apresentam com o pai como o proprietário dos bens e com direitos absolutos, ao mesmo tempo que reserva-se ao direito de manter certas atitudes que conduzam à ideia de que permanecem entre estas famílias vestígios de períodos anteriores.

Um dos aspectos apontados, do qual concordo, ainda que não comungue com a ideia de se tratar de um vestígio de períodos anteriores, é a presença da poligamia na maior parte das comunidades moçambicanas, especialmente nas famílias do sul do país. Ainda que, na sua maior parte, as famílias se apresentem como monogâmicas, a poligamia é um aspecto comum, principalmente nos espaços rurais, onde ela é interiorizada e socialmente aceita.

Entre várias razões que justificam a presença ainda recorrente da poligamia identificadas por Junod (1996), a mais comum é a infertilidade da primeira esposa e, com maior frequência, a necessidade de mão de obra para o trabalho agrícola. Arnaldo (2011), estudando os contextos em que a poligamia ocorre no seio da sociedade moçambicana, no geral, identificou, entre outras, as dimensões econômicas e culturais como categorias que explicam a poligamia. A infertilidade da mulher enquadra-se no contexto cultural de valorização da ancestralidade e descendência, que, por conseguinte, condena a esterilidade ou ter poucos filhos no casamento. Assim, a esterilidade da primeira mulher de um homem, por si só se torna num argumento para a prática da poligamia. Interessante e pouco falado, pois fica trancado ao cuidado de poucos, é o tratamento da infertilidade do homem que, ainda que não gere a condição de poliandria no sul, tal fato "possibilita" a partilha da mulher, como forma de garantir a reprodução humana dentro do casamento. Contado no romance de Chiziane (2002, p. 41) “no sul (...) só se entrega a mulher ao irmão de sangue ou de circuncisão quando o homem é estéril. (...) Solidariedade é partilhar pão, manta e sêmen”. Por sua vez, a categoria econômica eleva a importância da mulher no grupo familiar em que está inserida, quando torna a mulher a principal atuante do trabalho agrícola. Arnaldo (2011), citando Broserup (1970), classificou a sociedade com fracas tecnologias agrícolas como possuidoras de sistemas agrícolas femininos ou masculinos. Nos sistemas femininos, geralmente, pratica-se a rotação de culturas, em que as mulheres desempenham a maior parte do trabalho, elevando o seu valor econômico perante o 
homem. Tal fato o motiva a procurar mais mulheres e, consequentemente, mais filhos, como forma de obtenção de força de trabalho e possibilidade de obtenção de áreas mais extensas de cultivo, propiciando, assim, a poligamia.

Ora, Junod (1996) acredita que a poligamia tenha se estabilizado como costume, derivado do sistema de casamentos em grupo, considerando que a tribo por ele estudada, a tribo Tsonga, tenha passado por esse estágio de evolução familiar. Contando que o casamento por grupos descrito por Engels (1987) consistia em uma poligamia e poliandria em simultâneo, Junod (1996) considera como uma hipótese que na tribo Tsonga, por exemplo, o contexto de matlulana ${ }^{13}$ teria acabado com a poliandria.

As outras hipóteses na origem da poligamia levantadas por diversos autores, à semelhança de Junod (1996), seriam:

(i) as guerras, que diminuíram o número de homens; as altas taxas de fecundidade, com predominância para as mulheres se manterem vivas nos primeiros cinco anos de idade, bem como as diferenças de idade do casamento de acordo com o gênero.

(ii) o levirato, no contexto das leis de sucessão que regulam a família entre a maioria das tribos patrilineares. Nelas, permite-se que um irmão herde a viúva do irmão mais velho, quer seja casado ou não. Geralmente, consideram que o homem que possui um harém tem todas as chances de vir a ser um homem rico.

(iii) A prolongada abstinência sexual após o parto que, muitas vezes, nas sociedades africanas, chega a atingir os dois anos. Neste caso, a poligamia entra em socorro à privação sexual do homem.

Entretanto, Junod (1996) percebeu a existência de diferentes costumes que acredita terem contribuído para o surgimento da poligamia, contando com a hipótese de presença de monogamia primitiva.

O primeiro destes costumes é a incisão ritual na região inguinal feita à primeira mulher depois da morte do marido; não se faz nas outras mulheres. Da mesma maneira, o viúvo pratica o mesmo rito só quando lhe morre a primeira mulher, e não quando morrem as "mulheres pequenas". O segundo costume encontra-se nos ritos da

\footnotetext{
${ }^{13}$ Tabu que proíbe a dois irmãos terem relações sexuais ou afetivas com a mesma mulher (JUNOD, 1996).
} 
fecundação da povoação ${ }^{14}$ (...) a primeira mulher desempenha um papel especial nestas cerimônias significativas. (...) A primeira mulher é a verdadeira mulher e as outras não são mais que ladras (JUNOD, 1996, p. 261)

Este é um aspecto relevante quando se trata do casamento do chefe principal da povoação. Assim, na percepção do autor, esse caráter sagrado conferido à primeira mulher acontece, principalmente, pelo fato de o casamento com esta mulher ocorrer com o dinheiro dado pelos seus súditos, o que lhe garante poderes rituais importantes. Portanto, conclui o autor que este será o verdadeiro casamento, sendo as pequenas ou outras mulheres simples concubinas.

Fato interessante sobre a poligamia é o esforço empreendido por diversos autores na tentativa de encontrar explicações para a sua existência e permanência ainda pelos dias de hoje. Das estórias contadas por Paulina Chiziane em seus romances, a poligamia toma diversas dimensões. Ela é entendida como uma questão cultural, hábito e tradições enraizadas no seio da sociedade moçambicana, explicação que renega a condição de resíduo de um processo de evolução da família. Assim, a forma como Chiziane (2002) coloca a questão da poligamia em Niketche remete a observar a poligamia como um hábito gerado pelo interesse sexual e afetivo, o que de certa forma corrobora a ideia de satisfação do desejo sexual e afetivo do homem em abstinência:

A poligamia é uma rede de pesca lançada ao mar para pescar mulheres de todos os tipos, (...) poligamia é um uivo solitário à lua cheia. Viver a madrugada na ansiedade ou no esquecimento. Abrir o peito com as mãos, amputar o coração. Drená-lo até se tornar sólido e seco como uma pedra, para matar o amor e extirpar a dor quando o teu homem dorme com outra, mesmo ao lado. Poligamia é uma procissão de esposas cada uma com o seu petisco para alimentar o senhor (Chiziane, 2002, p.93).

Esta forma de encarar a poligamia remete a um sentimento de não concordância, um sentimento de abandono, tratando as diversas mulheres como amantes, mas, que em paralelo ao primeiro casamento, o oficial, foram formando famílias com o homem polígamo. Entretanto, vale lembrar que a autora se coloca no lugar da primeira esposa, ou pelo menos a oficial, a legítima, que, por causa da poligamia, sente-se acuada ao

\footnotetext{
${ }^{14}$ São ritos de definição do chefe da povoação. Esta é concedida ao irmão mais velho de uma comunidade (no caso a tribo tsonga, estudada por Junod). No ato da formação da mesma, o chefe deve ser o primeiro a ir à nova povoação e ter relações com a mulher principal, como forma de tomar posse da povoação. $\mathrm{O}$ símbolo de tomada de posse da povoação deve exclusivamente ser feito apenas com a primeira mulher, a principal e não com outra das suas mulheres, caso tenha outras. Esta mulher principal passa também a ser a dona da povoação tanto quanto é o chefe (JUNOD, 1996).
} 
mesmo tempo que revoltada por perceber a forma enganosa com que as mulheres restantes foram entrando na vida do seu esposo.

Se, por um lado, Chiziane conseguiu resgatar o lado tradicional da poligamia como expressão sexual e afetiva no seu livro "Niketche", por outro, no seu romance "O sétimo juramento" (2009), a escritora mostra a poligamia como um jogo de interesse de quem a pratica. A poligamia é, aqui, influenciada e originada por ganância no relacionamento e na forma individual de encarar a vida. A capacidade financeira e física do homem polígamo atrai mulheres também interessadas nesse "poder", ao mesmo tempo que o homem se vê ostentando tal "poder" em relação aos outros. Chiziane (2009) considera tal poder viciante, adquirido na mentira, no roubo, na traição, na superstição: "És rei! Serás ainda mais rico e terás muitos homens sob o teu comando" (Chiziane, 2009, p. 84). A ostentação o torna poderoso e com desejo de ter cada vez mais como forma de afirmação na sociedade: "Saúde, dinheiro e amor. Terás quatro esposas. Quatro pilares que te erguerão até ao mais alto dos montes. (...) Elas darão a vida por ti. (...) quatro é um número de estabilidade" (Chiziane, 2009, p. 87). Nesta estória, o homem assume a poligamia como um negócio, a única forma a ele imposta para adquirir o tão sonhado poder, tal como observado por Junod (1996), poligamia como forma de um homem se tornar rico e poderoso. Portanto, esta é uma percepção de poligamia que aflige de forma conflituosa a mulher, especialmente no sul do país. Ao mesmo tempo que as submete à condição de segunda, terceira esposa ou mesmo à condição de amante, a mulher nesta situação luta para que saia do anonimato, não no sentido de rejeitar sua condição, mas sim, procurando o caminho do prestígio e da aliança pelo casamento.

\subsubsection{O grupo étnico Chope}

Os Chopes são um dos menores grupos étnicos de Moçambique. São povos que têm suas origens na tradição Bantu, estando eles de acordo com Macamo (2008), entre os primeiros habitantes de Moçambique. Esses povos habitam as regiões ao sul das províncias de Inhambane e Gaza, áreas rodeadas demograficamente pelos povos Tsonga, dos quais são culturalmente aparentados. Essa região habitada pelos Chopes 
foi bastante afetada pela política econômica do sistema colonial, que a transformou numa reserva de mão de obra para as minas de ouro da África do Sul.

Tal como o nome da etnia, a língua falada por esses povos se chama chope. Segundo a tradição oral, o nome Chope deriva do conhecimento que este povo desenvolveu no uso do arco e flecha para se defender e/ou atacar seus inimigos das investidas nas cobranças de tributos, fundamentalmente investidas de Ngungunhane ${ }^{15}$ no século XIX, quando pressionava os povos Tsonga no sul de Moçambique para pagarem tributos. Os Chopes, diferentemente de outros grupos que usavam somente a lança (azagaia), já usavam o arco e flechas e, com ele, atacavam ao inimigo num ato chamado "ku chopa". Daí, a eles atribuiu-se o nome Chope.

De acordo com Pinho (2011), os chopes possuem um sistema de parentesco do tipo Omaha, isto é, primos paralelos são designados como irmãos e irmãs. Primos cruzados matrilineares são designados como mãe e irmão da mãe (ou pai da mãe). Primos cruzados patrilineares são chamados de netos. O autor acrescenta ainda que os chopes praticam o casamento exogâmico. O casamento com qualquer membro do clã da mãe ou do pai é expressamente proibido; como consequência, o efeito do sistema chope é espalhar alianças matrimoniais por toda sociedade (PINHO, 2011). Ainda segundo Pinho (2011), a linha de descendência desses povos é agnática, porém, existindo estruturas alternativas de parentesco matrilateral, o que sugere a existência de um sistema bilateral latente. Essa estrutura foi observada em um dos povoados estudados, em uma família que tem a sua antecedência bilateral. Pelo relato oral de um membro da respectiva família, tudo começa quando seu bisavô, ao se casar, convidou o irmão da esposa para frequentar a sua casa, e este acabou se casando com a irmã do seu cunhado. Este instalou sua residência no território da esposa, em terras cedidas pelo chefe do grupo familiar, que o recebeu e de lá continuou com a sua linhagem.

Culturalmente, os chopes são ricos em tradições e atividades. A música é a manifestação predominante da identidade chope. São detentores da Mbila/Timbila, que representa um instrumento e ao mesmo tempo que é música e dança:

Mbila é a versão dos Chope para o principal instrumento utilizado nesta forma de expressão cultural, um xilofone de construção artesanal bastante difundido no sul da África e eventualmente, em outras regiões do continente. "Timbila" refere-se aos grupos

\footnotetext{
${ }^{15}$ Quarto e último imperador do Império de Gaza, território onde atualmente é Moçambique. Foi chamado o Leão de Gaza devido ao seu comportamento hostil. Muito foi escrito sobre Ngungunhane. Neste trabalho, faz-se referência ao trabalho de Ferreira (1982), no qual pode-se inteirar melhor sobre o assunto.
} 
orquestrais compostos de várias mbila - de diferentes tonalidades, tamanhos e funções musicais - além de outros instrumentos, basicamente percussivos; na orquestra, os músicos são acompanhados por um grupo de dançarinos e todos são regidos por um "maestro". Assim, timbila é o nome dado a todo este complexo formado pela música, pela dança pela teatralidade e a literatura oral presente no conteúdo das suas canções (WANE, 2010, p. 8).

Esse instrumento levou à difusão internacional da música Chope, resultando no reconhecimento pela UNESCO como Patrimônio Cultural Oral e Imaterial da Humanidade.

Em termos de ritos tradicionais, os chopes se identificam pelos seus ritos de circuncisão (Wukhwera/In Sungi). Trata-se de um rito de iniciação feito a sangue frio (sem anestesia), geralmente num matagal cerrado, sem o qual um machope dificilmente pode ter mulher. Para eles, a circuncisão traz a conotação de pureza e maturidade e por isso representa o início da fase adulta. O ritual é exercido ao som do batuque e com muita dança e festa, o que mostra que a dança está presente em todos eventos, pois, através dela, expressam seus sentimentos, sejam eles, alegres ou tristes.

Os chopes são, em sua maioria, um povo rural e costeiro, habitando áreas de baixa altitude e de abundância de águas, mas com um solo bastante pobre e arenoso. Apesar disso, são tradicionalmente reconhecidos, principalmente como agricultores, dedicando-se ainda às atividades de manufatura e recreativas, sem contar a experiência secular no aproveitamento dos frutos silvestres na produção de bebidas alcoólicas. Segundo Ferreira (1982), o homem chope, desde cedo, primou-se por desenvolver uma economia autossuficiente e dotada de notável dinamismo na manufatura e nos trabalhos agrários, mostrando, assim, uma criatividade na confecção de ferramentas pesadas e nas tarefas que necessitassem do recurso de utensílios de ferro. É também tradição chope os homens desfilarem em poder de um pequeno machado (Ndzanga), de produção caseira, bem como o fabrico de Dithevele (espécie de caldeira), a partir do tronco da figueira africana para a destilação da aguardente.

Da mesma forma, o trabalho agrícola ficou sempre repartido entre os homens e as mulheres, sendo que, dada a forma intensiva da agricultura praticada, apoiam-se na ajuda que seus filhos podem lhes dar no trabalho de produção. Os homens também se dedicam na exploração de colmeias de abelhas domésticas, no fabrico e comércio de bebidas alcoólicas, bem como no comércio com povoações vizinhas. 
Na sua culinária, os chopes se destacam com a sua xiguinha ${ }^{16}$ de cacana $^{17}$ e com o feijão nhemba ${ }^{18}$, mathapa ${ }^{19}$, xibeye entre outros. Um condimento, não somente usado para a alimentação na culinária chope, mas como uma preciosidade, outrora usada no pagamento de tributos, é o óleo de Mafurra ${ }^{20}$ (M’tona/Munyanzi. Da Mafurra é ainda extraído o Matolo, unguento usado no tratamento das parturientes, das suas vestes e do enxoval (Si Beso) do bebê.

Os chopes têm fortes ligações com a sua origem e casa, de tal forma que raramente se tratam pelo primeiro nome, privilegiando a expressão wamhwani, que é "fulano de determinada família", em que a referência ao sobrenome é fundamental. Portanto, mostram uma organização em torno da nyumba (casa), onde o principal agrupamento doméstico é a família monogâmica, não se excluindo a existência da poligamia.

A nyumba (foto 4) é uma unidade doméstica de habitação, produção, consumo, religião e políticas autônomas. Possui uma organização interna definida hierarquicamente de acordo com as gerações, ordem de nascimento e sexo. Geralmente, a nyumba é composta de famílias alargadas. As gerações que compõem a nyumba são os pais, filhos e netos, em que os irmãos são distinguidos pela ordem de nascimento. $\mathrm{O}$ chefe do grupo familiar, em quase todas famílias estudadas, é o homem. Portanto, o homem chefe do grupo familiar dirige as mulheres, filhos, avós e todos que vivam na casa. Na nyumba, a relação entre os gêneros é bem estratificada. No geral, fato este observado no trabalho de campo, atribui-se autoridade quase que total ao homem, bem como os espaços e papeis para homens e mulheres são diferenciados e claramente definidos. Ainda que se observe uma coparticipação no trabalho agrícola entre homens e mulheres, aos homens são incentivadas buscas por atividades exteriores de trabalho assalariado, criação de gado, caça ou pesca ficando as mulheres com a responsabilidade geral da casa, isto é, cuidado com os filhos, a busca de água e lenha e a cozinha sem contar com o trabalho agrícola.

\footnotetext{
${ }^{16}$ Prato à base de mandioca, coco e amendoim, que pode ser misturado com cacana ou feijão nhemba.

${ }^{17}$ Planta usada para a alimentação e para fins medicinais, largamente difundida no sul de Moçambique.

${ }^{18}$ Um tipo de feijão que em Brasília é comum chamarem de feijão verde.

${ }_{19}$ Prato à base de folhas de mandioca com amendoim e coco, enriquecido com frequência com caranguejo.

${ }^{20}$ Fruto (sementes oleaginosas) extraído da mafurreira (tipo de árvore).
} 


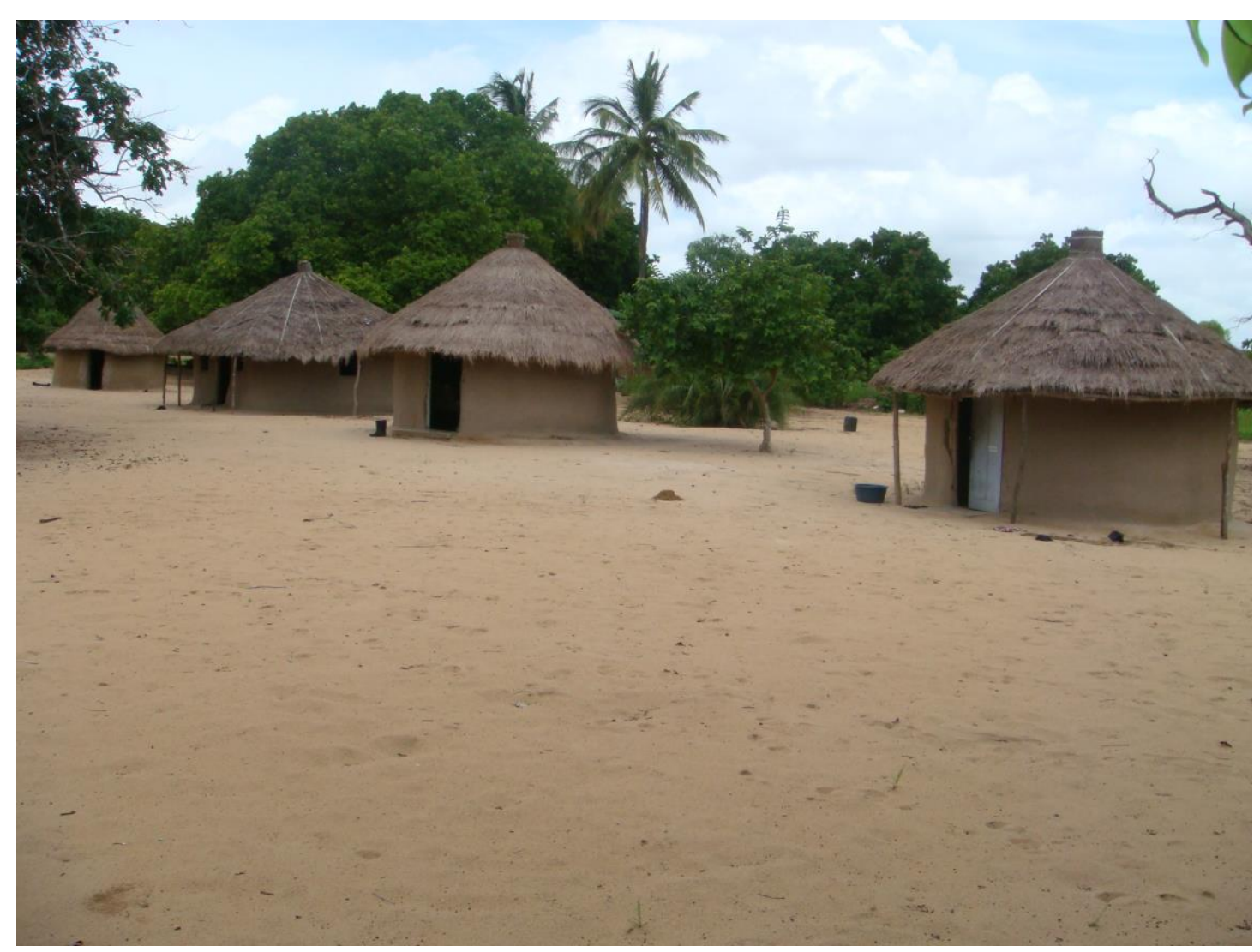

Foto 4. Exemplo de uma nyumba

Fonte: A autora

Geralmente, as residências dos componentes da nyumba são construídas individualmente, em pequenas palhotas, como mostra a figura, cujos tamanhos dependerão do quão alargado é o grupo familiar. Grande parte das famílias possui uma mistura de habitações entre uma forma precária ou melhorada, por meio de blocos cobertos de chapas de zinco. Os cômodos são construídos de forma separada, distribuídos isoladamente pelo terreno que constituem quartos de dormir. No centro, sempre junto a uma árvore (normalmente a mafureira), encontra-se o cômodo usado como cozinha, junto o celeiro.

Para Ferreira (1982), o acúmulo de atividades domésticas por parte dos homens, bem como a necessidade de compartilhar com as mulheres as tarefas agrícolas, explica a existência de um maior equilíbrio numérico entre os sexos e a menor incidência da poligamia entre os povos chopes (fato posto em questão para o que se observa na prática ultimamente). Para a autora, a poligamia mais se desenvolveu em casos específicos de alguns dirigentes de origem exógenas e/ou em alianças matrimoniais com chefes. Entretanto, no caso de um casamento polígamo do chefe do grupo familiar, cada esposa terá seu cômodo, que será constituído por um quarto e sala para a primeira esposa e 
apenas um quarto para a segunda esposa e mais, caso existirem outras. Os filhos pequenos dormem com as mães e os maiores terão seus cômodos espalhados pelo terreno familiar. No caso de existirem dois irmãos com as suas respectivas famílias, cada irmão irá construir seu cômodo de dormir de acordo com suas capacidades, partilhando da mesma cozinha e do celeiro, ou poderá ocorrer o fato de cada um construir sua residência, separando esses elementos de coesão do grupo (cozinha e celeiro), ainda que apenas um deles seja considerado chefe do grupo familiar. No caso em que o chefe do grupo familiar se responsabilize pelos pais, haverá um cômodo principal de dois compartimentos, que serão dos avós do grupo familiar.

A terra para estes povos é também o local onde descansam os ancestrais, sendo a campa de cada grupo familiar um dos lugares mais sagrados e de importância para o grupo. É, portanto, elemento de importância simbólica, pelos rituais e cultos a ela sujeita, especialmente o culto aos antepassados, adoração aos defuntos, etc. Daí, o controle da terra ser exercido pelo homem, mantendo a hierarquia entre os mais velhos e os mais novos. É tradição chope saber evocar os antepassados até no mínimo dez gerações, ato esse designado de "Ku ti Thopa/Ku Hlambanya" e que garante o conhecimento por parte dos seus membros da origem de sua etnia e nome. Para os chopes, as pessoas não morrem, deixam-nos (va hi side), desaparecem (va mwalade). A foto 5 mostra o momento de invocação que se realiza junto ao cemitério familiar, normalmente localizado junto às residências da família que compõe a nyumba. A cerimônia ocorreu em agosto de 2013. 


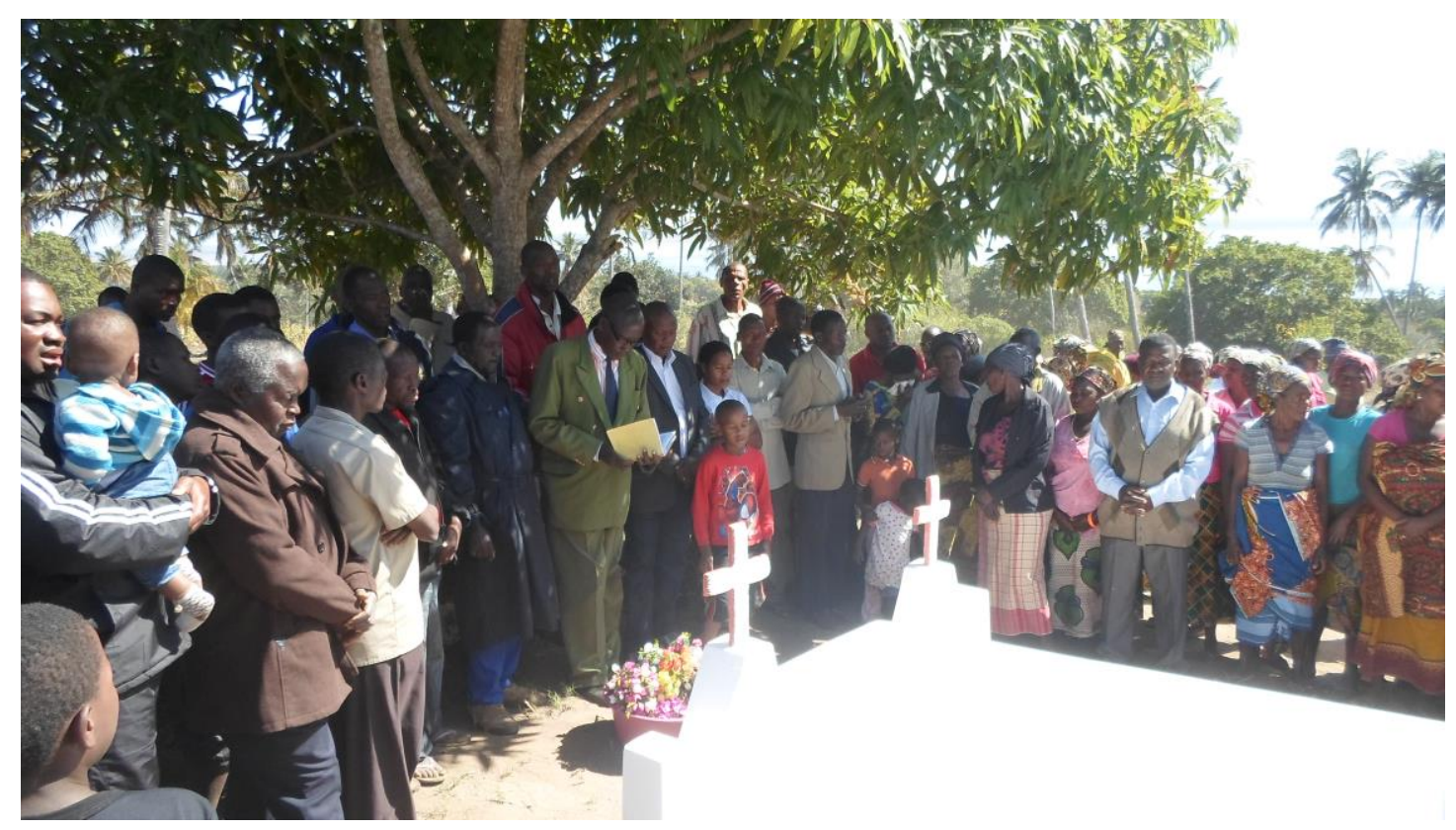

Foto 5. Um momento da cerimônia de adoração aos antepassados Fonte: A autora

O casamento entre os Chopes, em regra, é monogâmico, sendo um ritual exercido com maior importância para a sua forma tradicional - o lobolo, detalhado no capítulo seguinte, que na língua chope é chamado lowola.

Junod (1987) resume o significado do lobolo como a aquisição de um membro novo por parte de um grupo familiar. O grupo que cede o membro se sente lesado, reclama alguma coisa que, teoricamente, seria para reconstruir-se, com a aquisição de outra mulher para o grupo. Assim, a mulher adquirida, bem como os filhos por ela gerados, passam a pertencer ao conjunto do grupo familiar para onde foi lobolada. Nessa lógica, a mulher passa a ser esposa de todos os membros masculinos do grupo familiar, no entanto, não sendo permitidos que outros, além do seu esposo, mantenham relações sexuais com ela. Aos restantes, caberá esperar, em caso de morte do marido, recebê-la como herança.

O ritual do lobolo corresponde a três partes fundamentais, especialmente quando se trata das regiões rurais:

1. O noivo mostra a sua intenção de ter um laço matrimonial com a mulher, e esta é encaminhada por seus representantes aos familiares da futura noiva, numa cerimônia designada "hikombela mati", que literalmente traduzido, significa “estamos a pedir agua", que quer dizer "pedir a mão ou entrada"; 
2. Feito o pedido de entrada, é fornecida aos representantes do futuro noivo uma lista dos bens necessários para a realização do lobolo. Junod (1987), no conjunto das suas pesquisas, verificou que, por muito tempo, era hábito usar-se bois como forma de pagamento do lobolo. Tal fato veio a mudar quando, por diversas razões, especialmente as guerras, o gado tornou-se escasso, passando a serem usadas as enxadas. No entanto, a grande revolução veio mesmo com o aparecimento do dinheiro na sociedade Bantu e com a entrada dos indígenas no trabalho assalariado, em que passam, então, a ser incluídos nas listas do lobolo o dinheiro, joias e outros bens materiais facilmente adquiridos por dinheiro. Assim, reunidas as condições exigidas, os representantes do futuro noivo voltam à casa da noiva para a realização do lobolo, onde, a partir deste, a noiva passa a fazer parte do grupo familiar do noivo e o noivo, então, se efetiva como genro para a família da noiva. A foto 6 mostra parte dos bens exigidos numa cerimônia de lobolo da filha de um membro de uma comunidade chope. A cerimônia ocorreu em outubro de 2015;

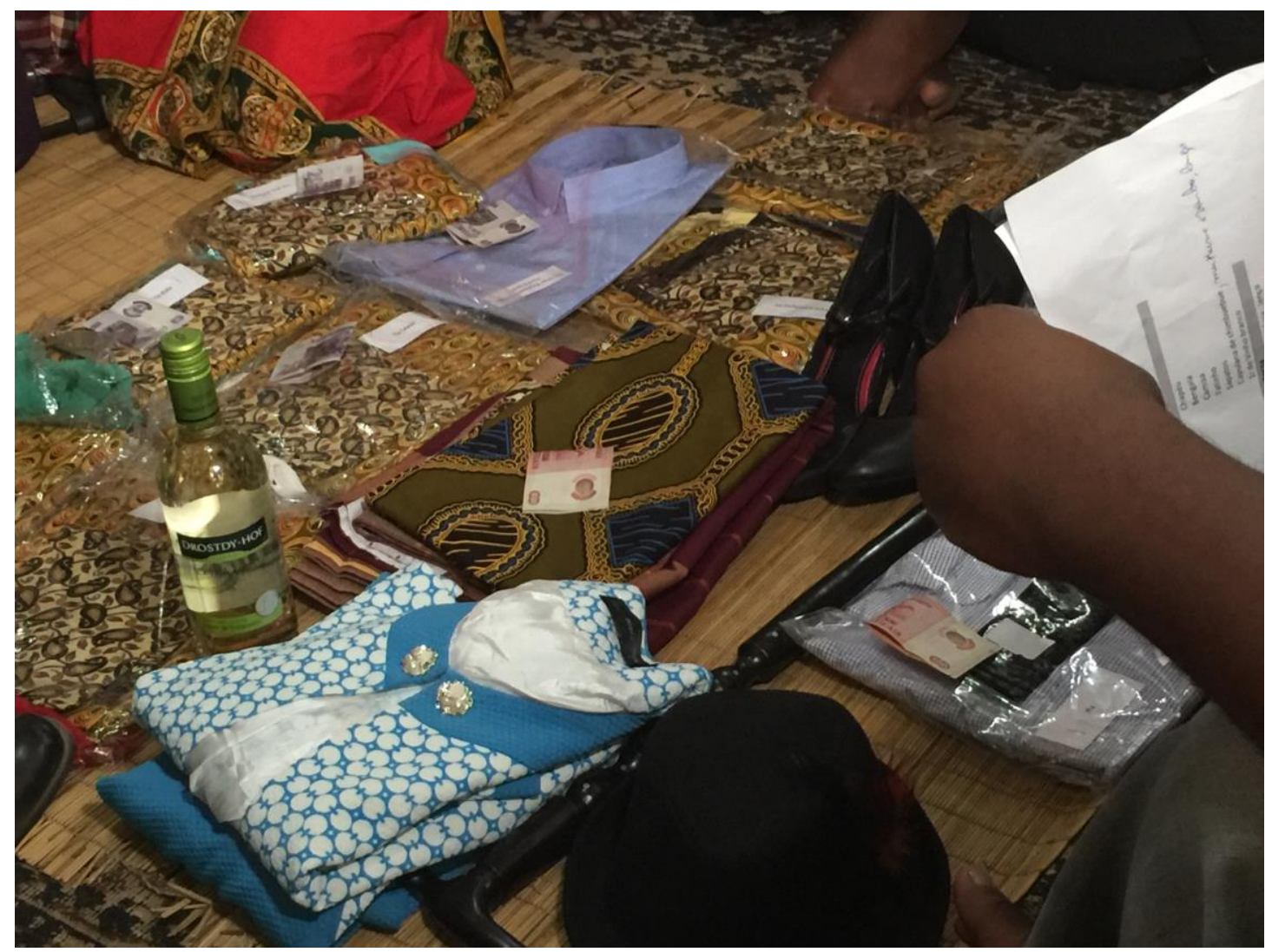

Foto 6. Parte dos requisitos exigidos para a cerimónia do lobolo.

Fonte: A autora 
3. Feito o lobolo, o casal parte para a sua noite de núpcias, enquanto a família da noiva se prepara para fazer a entrega formal da noiva com todos seus pertences no seu mais novo grupo familiar, numa cerimônia designada xiguiyane, que normalmente ocorre no dia seguinte ao lobolo, no espaço do grupo familiar do noivo. Cumpridas todas etapas, o casal passa então a viver com os familiares do marido ou em uma residência independente.

Este ato é de extrema importância para a mulher, pois representa uma forma de acesso à terra pela mulher, afinal, a família do marido deve indicar a nora recebida por via do casamento tradicional, a machamba que passará a cultivar e o local onde será construída a palhota (residência) do futuro casal. Além disso, o casamento tradicional, no contexto da família chope, é um acesso a um status social superior, fazendo com que muitas mulheres aceitem a condição de segunda ou terceira mulher de um homem, desde que passe pelo ritual do casamento tradicional. Para o homem, o casamento tradicional the confere direitos sobre a mulher e os filhos, mesmo que estes sejam resultado de adultério.

A par do casamento tradicional estão os rituais de levirato, herança das viúvas e o sororato, casamento com uma das irmãs da mulher falecida que, para Pinho (2011), são rituais os quais os chopes praticam de modo mais ideal que efetivo. Umas das cerimônias que ocorrem no levirato é a decisão da sorte da(s) viúva(s) no grupo familiar. Junod (1987) descreve o processo como dirigido pelas mulheres, especialmente as irmãs do morto, ainda que não possuam poderes absolutos. Segundo o autor, em caso de o homem possuir mais de uma mulher, a divisão obedece a seguinte regra:

1. A mulher principal é o "pilar da aldeia", isso caso tenha se casado com o chefe do grupo familiar. A esta é atribuída ao irmão, a seguir, ao defunto, que se torna o senhor da povoação. Existe relutância em aceitar que essa mulher abandone o lar pois, sendo o pilar da aldeia, sua partida pode significar o desaparecimento da aldeia. Entretanto, a ela é também permitida a recusa de um marido, desde que permaneça na aldeia sem marido, mostrando que as relações interpessoais por ela criadas na aldeia tomam aqui também um papel relevante. Se o defunto é o mais novo dos irmãos, em caso muito excepcionais, seu irmão mais velho pode herdar sua primeira esposa; 
2. As restantes são atribuídas aos irmãos subsequentes, podendo estas chegarem aos filhos do respectivo morto que, por ser a mulher "(...) a mais nova de todas; casou-se quando seu pai era já velho, e o filho mais velho do morto talvez seja de mais idade do que ela" (JUNOD, 1987, p. 190).

Entretanto, para Junod (1996), essas leis de sucessão que regulam as famílias contribuem para a existência e consolidação da poligamia. Em um dos povoados onde ocorreu o levantamento de dados, pôde-se destacar uma família de dois irmãos que mantiveram presente o sentido tradicional da nyumba. Numa mesma nyumba, os irmãos dividiram todas as atividades, bem como a responsabilidade dos seus componentes (esposas, filhos, noras e netos). Das observações feitas à família, bem como das conversas extraídas durante a entrevista coletiva, numa visita que tomaria o dia todo, pôde-se perceber, ainda que não de forma explícita, que essa família teria passado pelo contexto do ritual de herança da viúva, com a morte de um dos irmãos (o mais velho deles). Se não de forma efetiva, pelo menos existe a possibilidade de tal ter ocorrido de forma simbólica, forma esta considerada presente entre os chopes por Pinho (2001). Estavam bem claros e presentes todos rituais que representam o respeito com que é tratada a viúva herdada no que concerne a decisões a serem tomadas, rituais no condimento dos alimentos, entre outros.

Historicamente, o povo chope sofreu situações de preconceito e discriminação por parte de povos de outras tribos e depois, com a colonização portuguesa. Segundo Ferreira (1982), fugindo das hostilizações sofridas em consequências das invasões e destruições dos Angunes e depois pelos dirigentes do império de Gaza, especialmente Ngungunhane, vários chopes procuraram refúgio nas Terras da Coroa, bem como junto aos governadores de Inhambane e Lourenço Marques (hoje Maputo). Eles foram, pelos portugueses, usados apenas como força de trabalho intensiva e produtiva na agricultura e/ou como empregados domésticos (FERREIRA, 1982; MACAMO, 2008). Segundo Ferreira (1982), no contexto das guerrilhas em que os Chopes estiveram envolvidos, vários teriam sido massacrados e reduzidos à escravidão sob a designação de tinhloco (cabeças). Macamo (2008) diz que os chopes foram vistos, por muito tempo, como instrumentos de trabalho intensamente usados pelos portugueses na forma de empregados domésticos, que também receberam o desprezo por parte de outras sociedades que os consideravam serviçais e leais ao sistema de colonização portuguesa, devido à sua condição de dominados pelo regime. $\mathrm{O}$ autor acrescenta que, apesar de 
serem um povo criteriosamente rural, a cidade sempre foi, para eles, a representação de exploração e prosperidade e, com a política colonial do xibalo, intensificou-se sua condição de migrante para as cidades, onde aceitavam qualquer forma de trabalho que não os submetesse à condição de indigentes. Entretanto, a sociedade focava suas relações com indivíduos chopes nos aspectos de trabalho de salubridade (no qual facilmente podiam se empregar), a ponto de chegarem ao extremo de observarem um chope como uma "não pessoa", "uma pessoa das fezes" (MACAMO, 2008). Fontes orais chegam a afirmar que o tratamento pejorativo aos povos chopes chegou ao extremo de serem considerados "ninguém" em casos de acidentes, quando frequentemente se repetia a seguinte frase: "não morreu ninguém só estavam lá machopes".

Essa forma de relacionamento, com toda a certeza, gerou um espírito defensivo por parte de alguns membros da comunidade chope. Vários deles afastaram-se das suas origens, aliando-se mais ao sistema colonial, afinal, com ele poderiam ter melhores condições de trabalho em empregos domésticos nas residências dos portugueses ou por meio da política da assimilação, que possibilitou-os a aderirem ao ensino formal de alfabetização e se emanciparem por via da formação acadêmica profissional.

\section{Conclusão}

Procurou-se, neste capítulo, compreender a gênese da família sob visão Ocidental. O decorrer das leituras mostrou que, para o caso de Moçambique, tal qual Adesina (2012) mencionou com a situação de algumas comunidades africanas, a evolução da família foi um processo interrompido com a expansão das economias do Ocidente em busca da dominação no mundo.

Não se pretendeu, no capítulo, refutar o trabalho exaustivo apresentado por Engels. Contudo, é fato evidente que, abordando a questão da família africana no geral, e especificamente a família moçambicana, é de se concordar que existiu sim uma interrupção do processo evolutivo, bem como uma tentativa de eliminar as culturas seculares dos povos colonizados. Seus conhecimentos foram reduzidos a "nada", tudo isso com explicações aliadas a uma visão de necessidade de incutir aos nativos "valores ideais para a civilização". Na verdade, tais valores são a causa desse processo de 
interrupção. Constituem, hoje, um elemento de negação de culturas e tradições em algumas pessoas. Ainda que a África seja um continente de população negra, entre nós mesmos é perceptível, em alguns casos, que ser branco é condição para a submissão, é motivo de privilégios de diversa ordem, é eternamente o "patrão" para muitos. Afinal, a própria construção de identidades distintas dos povos africanos ficou abalada por percepções que nos conduziriam à condição de dependência, não somente nos modelos econômicos, como também, vale a pena incluir, nos modelos culturais e sociais outrora vividos nas sociedades ocidentais tipicamente patriarcais e machistas. 


\section{CAPÍTULO III - AS FORMAS DE ACESSO, POSSE E CONTROLE DE TERRA EM MOÇAMBIQUE}

\section{Introdução}

A terra é a base do poder político, onde se legitima a soberania de um Estado e o desenvolvimento econômico em geral. Nesse contexto, a terra representa um bem de extrema importância e com diferentes significados para qualquer sociedade. Para as sociedades rurais, o recurso à terra varia entre uma necessidade econômica, social, simbólica e/ou como recurso que garante a segurança social das famílias.

No contexto das comunidades rurais, a terra não é um bem ao qual a mulher tem facilidade de acesso. Tal fato está enredado num conjunto de relações desiguais entre homens e mulheres em seus contextos familiares, tradições e culturas. No geral, os direitos das mulheres acabam ficando comprometidos por estas relações, que conferem a categoria de chefe de família ao homem e, portanto, a posse dos bens da família, entre os quais, a terra.

É sobre essa temática que este capítulo ira se debruçar. Numa primeira fase, fazse a contextualização dos caminhos tomados para o acesso, posse e controle da terra em Moçambique, buscando caracterizar o período colonial e os contornos deste depois da independência até a atualidade. Em seguida, descortina-se a questão das leis de regulamentação de posse e controle e, com base nos dados de pesquisa, mostra-se como a mulher é colocada perante a sua comunidade, sua família, suas tradições e perante a lei, bem como as estratégias que ela utiliza nas questões de acesso, posse e controle de terra.

\subsection{O Contexto Geral da Questão Fundiária no Domínio Comunitário Rural}

A terra constitui um bem de suma importância em qualquer sociedade. Na África, e especialmente para Moçambique, dado o número acentuado da população habitando nos meios rurais, a importância da terra é maior, pois dela dependem para a 
subsistência, bem como para a reprodução da família. Benjamim Alfredo (2009), em sua tese de doutorado, mostra questões que constituem debates com relação à África também a Moçambique, sobre o tema da terra e sua posse. Entre elas, destacam-se:

1. A legislação sobre a posse e o uso da terra é adequada para a situação atual das economias, que cada vez mais estão carentes de terra para realizarem as suas atividades?

2. Qual a capacidade dos estados da região da África Austral na gestão da terra e dos recursos naturais?

3. Qual o papel das comunidades locais no processo de alocação da terra?

4. Que benefícios retêm os estados com a cedência de terras para investimentos estrangeiros?

5. Como evitar ou resolver os conflitos sobre a posse da terra?

6. Qual a vantagem da coexistência de dois sistemas de gestão da terra: o legal e o costumeiro?

7. Quais as vantagens da privatização da terra?

Estas questões são hoje levantadas diante das complexidades que alguns países africanos, em que Moçambique não é exceção, apresentam quando se trata da questão da propriedade da terra. Em paralelo a esses debates, pensar na questão dos camponeses e das mulheres, que na verdade caracterizam os espaços rurais na África, suscitam em outras questões diante da crescente modernização agrícola e da entrada de investimentos nos meios rurais, que têm se estendido para os sistemas de produção tradicionais praticados por esse grupo de pequenos produtores. Gengenbach (1998), em seu trabalho, mostrou diversos estudos em que vêm se debruçando, principalmente nas questões relacionadas aos camponeses e às mulheres, de forma que se torna pertinente acrescentar as seguintes questões:

8. Diante da cedente atração de investimento privado para a exploração do solo em diversos países africanos, como proteger os direitos dos camponeses à terra?

9. Reconhecendo que a mulher é a principal usuária da terra nos espaços rurais, de que forma esta estaria garantida nos seus direitos para o acesso à terra? 
3.1.1. A evolução histórica do acesso posse e controle da terra

A questão do acesso, posse e controle da terra sofreu diversas modificações ao longo do tempo, fundamentalmente ditadas pela intervenção colonial na África, que veio a mudar estruturalmente as formas existentes de organização das comunidades nativas.

$\mathrm{Na}$ África, a terra representa, para a grande parte da população rural, a base de existência e sobrevivência. O seu acesso e a sua posse pelos camponeses, que são os que em grande medida povoam os espaços rurais na África, são indispensáveis em face da produção que nela desenvolvem, bem como da sua utilização como espaço de reprodução social, criando raízes, expressando seus saberes e tradições milenares. A organização anterior ao período colonial centrava-se nos chefes tradicionais que lideravam todo o processo de vida dentro da comunidade. Assim, cabia a estes e seus régulos controlar, além das populações junto às suas comunidades, as pequenas parcelas de terras localizadas dentro de um determinado regulado. Segundo Alfredo (2009), o ancião da geração mais antiga tinha a responsabilidade sobre a fertilidade dos solos, cabendo-lhe a tarefa de gestão e organização dos ritos necessários para que tal fertilidade se observasse, além da distribuição da terra pela comunidade, famílias e pessoas individuais.

No entanto, a invasão colonial veio a criar uma distorção no seio das populações rurais que, além de retirar-lhes as parcelas de terras férteis, alterou sobremaneira as formas de posse e uso destas. Segundo Direito (2013), um dos aspectos marcantes para as comunidades locais foi o não reconhecimento aos régulos e outras chefaturas indígenas dos direitos de propriedade sobre a terra, ainda que não existisse uma individualização da terra em Moçambique, sendo o regime de usufruto coletivo, mas, sob controle do regulado. Esse também foi o argumento levantado por Direito (2013) para justificar que a falta de individualização representava, no contexto da evolução da família, um atraso que impossibilitava o colono a observar o indígena com capacidade e preparo para entrar no processo de individualização da terra. Portanto, tal fato ditou a coexistência de dois sistemas de propriedade: o comunal, para os indígenas, regidos pelas leis costumeiras, e o individual, para os tidos como evoluídos na percepção de propriedade. Disso resultou a dualidade nas regras de posse da terra, observável na 
atualidade, com as formas costumeiras e legais caminhando lado a lado, legitimadas e constitucionalmente aceitas.

Na verdade, Alfredo (2009) constatou que, para o caso da África Austral, os direitos costumeiros da terra se assemelham, com a característica em comum de serem exercidos por um grupo que detém o poder na comunidade de forma absoluta, exclusiva e perpétua, com a sucessão de tais direitos para os seus dependentes. Acrescenta o autor que este pequeno grupo tem a terra como um bem sagrado, pertencente ao Divino e, por isso, não cogitam a hipótese de que a terra seja alienada ou dada com garantia ou qualquer outra forma semelhante, sendo que, a quem fosse-lhe concedida a graça de controlá-la, tinha em si, também, os poderes que emanam do Divino. Nessa lógica, fazia então sentido a propriedade comunal em detrimento da propriedade individual da terra. No entanto, esta é uma posição que, em séculos, deixou de fazer sentido, porém, sua utilização e aceitação consagraram o direito costumeiro como uma realidade na África. Entretanto, a relação entre o direito costumeiro e o sistema jurídico legal sobre a terra torna o primeiro válido somente se sua formulação se conformar com o postulado pela lei formal.

Pelo sistema costumeiro, os modos de aquisição do direito sobre a terra devem verificar:

1. A ocupação da terra por um fato que confirma a sua utilização organizada e aproveitamento visível;

2. A ocupação que resulte de um ato que, à luz dos costumes e de boa fé, possa se equiparar (doação ou venda);

3. O direito de sucessão para alguém devidamente reconhecido pela comunidade.

Caso não se verifique estes elementos, em qualquer das circunstâncias, os direitos sobre a terra poderão não ser reconhecidos pela comunidade ou pelo Estado (ALFREDO, 2009).

De um modo geral, Whitehead e Tsikata (2003) afirmam que, na África, conseguiu-se manter os dois regimes de posse durante a colonização e por motivos diferentes houve uma tentativa de preservação dos direitos costumeiros de posse de terra, respeitando-se a propriedade comunal em detrimento da individual. Tal fato veio a mudar quando verificou-se a intensificação do desenvolvimento agrícola, que via os direitos costumeiros como obstáculos aos objetivos de produção, sendo a propriedade 
individual a opção mais interessante para o investimento, como acrescentam Whitehead e Tsikata (2003).

Em Moçambique, essa coexistência entre o poder colonial e o sistema costumeiro local foi altamente tensa, fato que se acentuou quando Portugal, diante da sua fraqueza econômica, viu-se obrigado a ceder parcelas do território às companhias majestáticas, que passaram a gerir o centro e o norte do território moçambicano. Essa forma de alocação de terras foi designada de $\operatorname{prazos}^{21}$. Neles se desenvolviam diversas atividades, com destaque para o comércio de escravos, além de se utilizar a mão de obra local para as grandes plantações ou monoculturas desenvolvidas para a exportação, como o algodão, a cana de açúcar, o chá, o tabaco, o sisal, entre outras. Sabe-se que os prazos representavam autênticos poderes, chegando a posicionar-se como se tratassem de governos independentes, pois, além de gerirem a terra a eles cedida, cobravam impostos, implementavam leis produzidas por órgãos sem legitimidade alguma e cunhavam moedas, entre outras formas de demonstração de poder (CABAÇO, 2007; ALFREDO, 2009).

Ainda assim, no contexto dessas grandes mudanças na utilização da terra, teoricamente, foram preservadas não só as formas costumeiras, como os direitos das populações indígenas à terra. No entanto, de fato, as populações indígenas passavam a ocupar as terras marginais, ou seja, residuais, não somente da grande agricultura, como também da população não indígena, contando, para tanto, com terrenos menos férteis, com fraca capacidade de gerar bons resultados diante das práticas agrícolas aos moldes da população indígena. Consequentemente, poucas oportunidades de sobrevivência restavam aos indígenas senão inserir-se no mercado de trabalho. Para Direito (2013, p. $13)$,

(...) a crescente presença branca na colónia foi paulatinamente expulsando a população rural das áreas mais férteis (...) acabaram por contribuir para uma crescente desestruturação dos processos de produção camponesa e por acelerar a criação e expansão de uma força de trabalho para o mercado.

Para Alfredo (2009, p. 41-42), ainda que os direitos das populações fossem legalmente reconhecidos pelo governo colonial, a diminuição das áreas de cultivo em favor da grande agricultura gerou “(...) um aumento da dependência do mercado de

\footnotetext{
${ }^{21}$ Os prazos foram uma das formas que tomou a colonização portuguesa em Moçambique, nos anos 1600. Correspondiam a concessões de terras que eram definidas por duas ou três gerações e transmitidas por via feminina (mais especificamente, a filha mais velha) (UEM, 1983).
} 
trabalho como forma de obter rendimentos numerários indispensáveis para a sobrevivência e reprodução da família rural”. Segundo Hernández (2009), como resultado da introdução da agricultura comercial, observou-se uma mudança estrutural especialmente nos espaços rurais, onde os camponeses locais passam, então, a se subordinar às relações de produção capitalistas trazidas pelos colonos. O autor acrescenta que, na perspectiva de busca de rendimentos numerários, as populações, por exemplo, das regiões do sul do rio Save, viram nas migrações para as plantações de cana de açúcar a forma de se inserirem no contexto capitalista, o que mostra que o fenômeno da migração é de longa data e culturalmente aceito, pois representava o cotidiano das populações, especialmente do sul do país.

Com a independência do país, o então Governo da FRELIMO transformou a propriedade da terra numa questão nacionalista (NEGRÃO, s/d), visando ao reconhecimento da necessidade de mudança de uso da terra em favor da população nativa nas aldeias comunais. A terra, bem como os recursos naturais, passa a ser propriedade do Estado, pertencendo ao povo moçambicano, sendo o Estado quem determina as formas e as condições do seu aproveitamento e do seu uso (MOÇAMBIQUE, 1990).

Ainda que se abrisse espaço para que os detentores do direito da terra do período colonial regularizassem seus direitos para o contínuo uso e aproveitamento, na prática, esses não exerceriam o direito de propriedade sobre a terra, mas sim o direito de uso e aproveitamento pois, já nesta altura, a legislação impedia a sua venda, arrendamento, hipoteca ou penhora (ALFREDO, 2009).

Apesar da política de nacionalização verificada após a independência nacional, alguns autores afirmam que não se verificou em Moçambique uma redistribuição de terras aos nativos, mas a transformação de propriedades agrícolas privadas em machambas estatais. Afinal,

Os camponeses não viram concretizadas as suas expectativas de recuperação das terras ocupadas com a colonização. As empresas estatais e as cooperativas, no quadro da socialização do meio rural e da coletivização agrária ocuparam as terras deixadas pelas empresas dos agricultores que abandonaram o país (MOSCA, 2014, p. 13).

No entanto, pelos princípios da política de socialização (“a terra é de quem a trabalha"), o setor familiar permaneceu com o direito à terra nos locais onde outrora já trabalhavam, o que excluía as áreas extensivas e não exploradas, ainda que fizessem 
parte do seu território, o que, de certa forma, retirava os direitos naturais das famílias (ALFREDO, 2009).

No contexto de produção agrícola, Alfredo (2009) diz que o governo da FRELIMO procurou observar o campesinato e as sociedades camponesas como uma realidade homogênea, capaz de operar fora dos contextos de acumulação sem depender do mercado, pois tinha a alternativa de se retirar da economia mercantil e era dotado de capacidade de auto sustento. Na sequência, a estratégia de concentração de recursos técnicos nas unidades de produção estatal era tomada como o caminho mais rápido para se alcançar o desenvolvimento, sendo que, na prática, entendia-se estarem asseguradas às famílias a posse da terra para a produção de alimentos, e os rendimentos monetários seriam buscados nas grandes empresas agropecuárias. Tal fato culminou, segundo autores como Castel-Branco (1994), no não enfrentamento do problema da transformação da estrutura das relações de produção e de troca nos meios rurais, em que, na prática, apenas houve a mudança do centro de acumulação do setor capitalista colonial e multinacional para o setor estatal, mantendo-se intactas as estruturas e as relações de produção herdadas.

A Constituição da República de Moçambique de 1990 veio reforçar o legado da propriedade da terra em favor do Estado, quando, no artigo 109, diz que: "A terra é propriedade do Estado. Como meio universal de criação de riqueza e do bem-estar social, o uso e aproveitamento da terra é direito de todo o povo moçambicano" (MOÇAMBIQUE, 1990). Ao mesmo tempo, verifica-se uma mudança da política econômica, em que Moçambique alia-se aos preceitos da economia de mercado. No contexto da implementação dos programas estruturais no meio rural, as áreas de terra estatal passam para o setor privado e para o campesinato mais próspero, pois, objetivava-se para o setor agrícola:

1. Reforço do papel do setor privado;

2. Reforma da política de preços;

3. Alocação dos fatores de produção pelos mecanismos de mercado.

Para Castel-Branco (1994), o fim da guerra civil, que teve como consequência o abandono de grande parte da população rural para as grandes cidades, deixando grandes áreas livres para grupos favorecidos pela política do mercado livre, tornou a pressão sobre a terra um dos aspectos centrais, porém, subvalorizados pelos programas de reforma estrutural. Afinal assistiu-se a uma crescente tendência para a requisição de 
terras nas áreas rurais com maior potencial econômico por parte dos agricultores privados, ao mesmo tempo que as famílias rurais retornavam às suas terras de origem, sendo que parte delas se encontrava ocupada pela agricultura mais próspera.

Entretanto, diante de todas constatações que levavam ao questionamento das políticas governamentais, há o reconhecimento de que a atual Lei de Terras, aprovada em 1997 como resultado da Política Nacional de Terras formulada em 1995, foi a grande sacada do governo. De acordo com Alfredo (2009), a Política Nacional de Terras surge em decorrência de formulações nada claras em relação às formas de utilização da terra, depois que a sua titularidade foi revertida em favor do Estado na altura da Independência Nacional. Para tal, houve a necessidade de criar-se um mecanismo adequado que possibilitasse uma melhor colocação do recurso em favor da nação.

Alfredo (2009) descreve como objetivos da Política Nacional de Terras:

1. A criação de condições para um acesso à terra por parte das camadas mais pobres (os agricultores e a população rural no geral) como forma de incentivar a produção agrícola que garantisse a segurança alimentar das famílias e da nação;

2. A criação e estímulo do auto emprego nas regiões agrícolas;

3. O desenvolvimento da produção agrícola que também privilegiasse culturas de alto rendimento e que alimentasse tanto o mercado interno como as exportações, de forma a diminuir o desequilíbrio da balança de pagamentos do país;

4. A implementação de um processo de gestão dos recursos materiais de forma sustentável.

A verdade é que a Política Nacional de Terras abriu espaço para a percepção de que havia um quase generalizado desconhecimento sobre a então existente legislação da terra, bem como a lacuna para a efetividade da lei de terras e consequente implementação. É assim que, segundo Alfredo (2009), analisados os fatores negativos, houve o reconhecimento de que a legislação sobre a terra deveria:

1. Ser a mais simples e adequada possível, para a fácil compreensão de todos os intervenientes;

2. Incluir as comunidades e seus costumes como elementos fundamentais a serem considerados; 
3. Facilitar e cobrar do Estado, como proprietário da terra, a sua administração de forma eficiente no que concerne aos conflitos de terras e ao mercado clandestino de terras.

Disso resulta o reconhecimento da existência dos direitos tradicionais sobre a terra, bem como o reconhecimento do papel desempenhado pelos líderes comunitários na resolução de conflitos locais de posse de terra.

Nessa lógica, a Lei de Terras de 1997, no seu artigo terceiro, veio reforçar a preservação da propriedade pública do solo, pois "a terra é propriedade do Estado e não pode ser vendida ou, por qualquer forma alienada, hipotecada ou penhorada" (MOÇAMBIQUE, 1997); assim, o artigo 29 define que os camponeses e suas comunidades continuam com os seus direitos de explorar a terra reservados, passando a serem gratuitos o uso e o aproveitamento da terra quando se destinam:

a) ao Estado e suas instituições; b) às associações de utilidade pública reconhecidas pelo Conselho de Ministros; c) às explorações familiares, as comunidades locais e as pessoas singulares que a integram; d) as cooperativas e associações agropecuárias nacionais de pequena escala (MOÇAMBIQUE, 1997).

Entretanto, a Lei de Terras se baseia no Direito de Uso e Aproveitamento de Terra - DUAT, por pedidos dirigidos ao Estado para a utilização da terra em Moçambique, sendo conferidos tanto aos cidadãos nacionais como aos estrangeiros. O DUAT, para os nacionais, pode ser atribuído a pessoas individuais ou coletivas, podendo ser homens, mulheres ou as comunidades locais. Aos estrangeiros, o DUAT é concedido mediante apresentação de um projeto de investimentos devidamente aprovado. Entretanto, para pessoas individuais, pesa a exigência de serem residentes em Moçambique por pelo menos cinco anos, enquanto que, para pessoas coletivas, a exigência é estarem constituídas ou registadas em Moçambique.

Os artigos $12^{\circ}$ e $15^{\circ}$ da Lei de Terras referem que:

O direito de uso e aproveitamento da terra é adquirido por: ocupação por pessoas singulares e pelas comunidades locais, segundo as normas e práticas costumeiras no que não contrariem a Constituição. A comprovação do direito de uso e aproveitamento da terra pode ser feito por prova testemunhal apresentada por membros, homens e mulheres, das comunidades locais (MOÇAMBIQUE, 1997).

Portanto, A Lei tem o mérito de reconhecer, de forma explícita, a necessária participação da comunidade na gestão, resolução de conflitos e no processo de titulação, usando, entre outros, normas e práticas costumeiras. 


\subsection{A Autoridade Tradicional como Elemento Central na Posse da Terra}

Um dos atores sociais de destacável importância junto às comunidades locais são as autoridades tradicionais. As autoridades tradicionais são tidas como um poder local e/ou poder exercido por pessoas influentes e com legitimidade para decidir sobre a vida da comunidade e dos recursos nela existentes, no que concerne à sua forma de uso e aproveitamento. A Lei de Terras, no seu artigo primeiro, define a comunidade local (onde opera o poder da autoridade tradicional) como:

(...) agrupamento de famílias e indivíduos, vivendo numa circunscrição territorial de nível de localidade ou inferior, que visa a salvaguarda de interesses comuns através da proteção de áreas habitacionais, áreas agrícolas, sejam cultivadas ou em pousio, florestas, sítios de importância cultural, pastagens, fontes de água e áreas de expansão (MOÇAMBIQUE, 1997).

Ainda que instituídas e reconhecidas por Lei, Moçambique continua sendo palco de debates sobre o poder e papel das instituições políticas tradicionais. De acordo com Lourenço (2007), continuam não estando claras, nas sociedades africanas no geral e, em particular, para Moçambique, a separação do que pertence ao domínio "tradicional” com o que então irá constituir o "moderno", tampouco estes dois elementos estão, de fato, enquadrados numa realidade política. Tal fato, na opinião de Lourenço (2007), deu-se pela importância que outrora representaram para o governo colonial, quando chegaram a ser usados como intermediários administrativos do poder colonial junto às comunidades que tutelavam.

$\mathrm{Na}$ verdade, Meneses (2009) diz que o reconhecimento das autoridades tradicionais como sistema de administração indireta foi legalizado na gestão colonial em Moçambique em 1929, quando então passam a ser reconhecidos um régulo para cada território tradicional. Entretanto, a autora salienta que esse poder representou para o colono o caminho mais fácil de envolver os nativos nos objetivos da colônia. Afinal, o poder tradicional foi usado pelo sistema colonial no controle de cobrança dos impostos dos indígenas, na garantia do recrutamento da força de trabalho e na resolução de conflitos das populações que tutelavam e, em certos casos, como acrescenta Lourenço (2007), os nativos se tornaram até mesmo agentes de policiamento local da estrutura colonial. Não foi de se admirar que, pouco a pouco, esses títulos tradicionais foram perdendo a essência do seu conteúdo para as suas comunidades, passando estas 
a observar os régulos e seus adjuntos como parte integrante e efetiva do Estado colonial (LOURENÇO, 2007; MENESES, 2009). Ainda assim, para Cristiano José (s/d), a colaboração das autoridades tradicionais com o governo colonial foi bastante controversa, pois o seu posicionamento variou entre resistência, resignação e aliança com o poder colonial.

Apesar disso, sabe-se que as autoridades tradicionais exerceram um papel relevante para a colocação da população indígena no contexto colonial. Segundo Meneses (2009), a busca de identidade indígena foi definida pelas suas ligações ancestrais a uma região. Na sequência, o local de nascimento e/ou a associação a uma linhagem de um determinado grupo seria o meio pelo qual estariam representados seus interesses, pois estes não eram considerados de forma individual, mas sim, vistos como interesses da coletividade. Para Cabaço (2007), isso significou retirar qualquer possibilidade de existência individual ao indígena, se não colocando-o apenas como membro de uma "tribo". Afinal, seria esta, a tribo, o local da representação do indígena. Portanto, a autoridade tradicional, como coordenador das atividades do grupo, tomaria importância sobremaneira para essa representação do indígena.

Ora, se no contexto do período colonial o indígena deveria estar assente numa pertença étnica (tribo), para Meneses (2009), a FRELIMO, com o seu projeto revolucionário, focou suas ações com vista a levar a igualdade de todos os cidadãos, independente de suas origens étnicas, com o único objetivo de "construção de uma nação" (grifo nosso). Assim, passa a ser questionado o poder tradicional, com a chegada da independência. Na verdade, a essência do poder tradicional como poder opressor da população indígena e os projetos desenhados pela FRELIMO no intuito de libertar o indivíduo da opressão representava uma relação conflituosa e percebida por ambas as partes, tanto que, segundo Lourenço (2007), os chefes tradicionais chegaram, na sua atuação, a colocar-se a colaborar em campanhas contra a libertação de Moçambique.

Levando em conta os princípios filosóficos que guiaram a revolução liderada pela FRELIMO, a saber: o "escangalhamento do Estado colonial"; a "criação do Homem novo" e a "destruição das ideias coloniais e práticas obscurantistas” (MENESES, 2009, p. 25), é natural que neles constassem a abolição dos sistemas tradicionais, que era vista como uma forma de destruir as estruturas do passado e mudar radicalmente a estrutura governativa deixada pelo poder colonial.

Logicamente, mesmo se tal destruição do poder tradicional não tenha sido efetivada na prática, pelo menos observou-se que, no período pós-independência, o 
poder tradicional ficou marginalizado pelo então governo da FRELIMO. O poder tradicional também ficou fragilizado na sua essência, embora não tivessem perdido, de fato, seu reconhecimento e sua coexistência junto às comunidades rurais (LOURENÇO, 2007). Afinal, acrescenta José (s/d), no contexto político pós-colonial, houve uma reciclagem e recriação da legitimidade do poder tradicional e sua integração junto às estruturas partidárias, de forma a conquistar, preservar e ampliar seus espaços de atuação, com base no poder tradicional.

Portanto, ainda que tivesse ocorrido uma reação momentânea de negação do poder tradicional diante do poder que este representava, ou seja, a sua condição de representação de uma cultura, isso implicou, no contexto comunitário, na perda de valores culturais e tradições existentes.

A verdade é que o intuito de manter a organização das populações e a coesão dos grupos populacionais prevaleceu como elemento central de atuação do governo da FRELIMO. Com isso, foram criadas outras alternativas ao poder tradicional, com novas figuras junto às comunidades. É dentro desse contexto que surgem os grupos dinamizadores e, em seguida, os secretários de bairro, entre outros elementos de coesão. Não à toa que, de acordo com Meneses (2009), estas novas estruturas administrativas ${ }^{22}$, ainda que totalmente partidárias e ligadas à FRELIMO, foram criadas para gerirem questões sociais, mediarem conflitos e exercerem o policiamento, a administração e a regulação das comunidades de sua jurisdição.

Na sequência, seria no contexto da guerra civil, ou seja, no final do conflito armado em Moçambique que opôs a FRELIMO e a RENAMO, de acordo com Meneses (2009), o momento em que as autoridades tradicionais voltariam a fazer sentido no país. Afinal, diversos autores compartilham da opinião de que essas autoridades teriam sido altamente usadas, tanto pela FRELIMO como pela oposição, no apoio aos processos eleitorais junto às comunidades (LOURENÇO, 2007; MENESES, 2009; JOSÉ, s/d). Na sequência, no Decreto-Lei ${ }^{\circ} 15$ de 20 de Junho de 2000, aprovado pelo conselho de Ministros no quadro da descentralização administrativa, é, então, formalmente reconhecida a:

(...) valorização da organização social das comunidades locais e aperfeiçoamento das condições da sua participação na administração pública para o desenvolvimento sócio cultural de Moçambique, (...),

\footnotetext{
${ }^{22}$ Meneses (2009) toma como exemplo a figura do secretário do bairro, uma figura relevante em nível local, que acumulava tarefas políticas de representação ao partido FRELIMO no bairro e tarefas administrativas.
} 
tornando-se necessário estabelecer as formas de articulação política e/ou administrativa dos órgãos locais do Estado com as autoridades comunitárias. Para os efeitos do presente Decreto-Lei são autoridades comunitárias os chefes tradicionais, os secretários de bairro ou aldeia e outros líderes legitimados como tais pelas respectivas comunidades locais. No desempenho das suas funções administrativas, órgãos locais do Estado deverão articular com as autoridades comunitárias, auscultando opiniões, na concepção e implementação de programas e planos econômicos, sociais e culturais em prol do desenvolvimento local (LOURENÇO, 2007, p. 204)

Assim, apesar da ambiguidade em termos de seu enquadramento na estrutura política administrativa do Estado moçambicano, o reconhecimento formal que as autoridades tradicionais usufruem junto às comunidades e sua legitimidade e poder incontestáveis mostram o retorno à tradição e o reviver de crenças e costumes, ou seja, a essência da cultura que caracteriza-nos e identifica-nos como Moçambicanos.

\subsection{Mecanismos de Controle e Posse da Terra em Moçambique}

Como foi referido anteriormente, em Moçambique, a terra é propriedade do Estado e, para a comunidade, representa uma dádiva Divina, pertencendo ao conjunto da comunidade. Assim, cabe ao chefe dessa comunidade, portanto, a autoridade local, também designada autoridade tradicional, determinar as regras de sua posse, ocupação e uso por parte particular, sendo o critério determinante os princípios locais onde o acesso, uso e controle é regulado pelas suas próprias tradições.

Transpondo o modelo tradicional de acesso e controle de terra para a família, o trabalho de Gengenbach (1998) sintetiza melhor a forma como ele ocorre. Segundo o autor, de um modo geral, quem detém o controle das terras é o regulado, quem arbitra sobre a coletividade. Este, por sua vez, divide a terra pelos grupos familiares residentes em seu povoado. Por grupo familiar, Gengenbach (1998, p. 10) refere-se ao "chefe do grupo, seus irmãos, os filhos (homens) casados (ligação agnática), a esposa ou as esposas do chefe do grupo e sua prole. O grupo familiar é composto de casas formadas por cada mulher casada e seus filhos" (tradução nossa).

Portanto, cabe ao chefe de cada grupo garantir que todos membros tenham acesso à terra suficiente para agricultura e residência. Para Alfredo (2009), o controle da terra opera-se, normalmente, junto às famílias e/ou indivíduos isolados, que podem, 
nomeadamente, fazer o repasse, aluguel ou empréstimo da terra. No entanto, a linhagem ou outra hierarquia da comunidade, no caso, o regulado ou a autoridade tradicional, pode ter o direito de aprovar ou não quando se trata do repasse dessa terra.

$\mathrm{Na}$ verdade, ainda que se fale de controle de terra por parte do regulado, dos grupos familiares ou dos indivíduos, na prática, o fato de a terra em Moçambique ser da pertença do Estado, não se admite que particulares detenham de títulos de propriedade da terra. O que indivíduos pertencentes a uma comunidade podem obter, para lhes garantir a posse e, consequentemente, o controle da terra, é o direito de posse das mesmas. Segundo Alfredo (2009), a posse representa uma situação em que a pessoa que tem acesso à terra é capaz de fazer algum uso do recurso, podendo a posse representar um poder correspondente ao exercício do direito de propriedade ou situação na qual a pessoa terá o controle de alguma coisa. No contexto da terra, o autor considera que o conceito da posse de terra se estende às condições segundo as quais são definidos os direitos e obrigações de quem ocupa ou detém a terra.

É nesse contexto que, com o auxílio da lei formal, indivíduos ou famílias pertencentes a uma comunidade podem obter o DUAT, que significa o Direito de Uso e Aproveitamento da Terra. O DUAT é definido pela Lei de Terras, no seu artigo primeiro, como: “(...) direito que as pessoas singulares ou coletivas e as comunidades adquirem sobre a terra, com as exigências e limitações da presente Lei”. Nesta lógica, cabe ao Estado gerir os direitos sobre a terra, podendo:

Em caso de extrema necessidade e atendendo às questões de justiça social, o Estado também procede a redistribuição da terra, como forma de permitir a sua utilização equilibrada e racional pelas várias camadas da sociedade, com realce para as camadas rurais camponesas que mais necessitam da terra para a sua subsistência (ALFREDO, 2009, p. 125).

Entretanto, é com base na Lei de Terras que o Estado toma as suas decisões para a concessão do DUAT. No entanto, a ocupação das terras pode resultar de um ato costumeiro dentro do que é definido pelos princípios tradicionais, a que todos devem obediência e ocupação por boa fé é $^{23}$ e por autorização formal. No primeiro caso, apenas é permitido para pessoas nacionais e comunidades locais; o segundo, apenas para pessoas nacionais e o terceiro caso, quando se trata de sujeitos de direito nacionais e também estrangeiros (ALFREDO, 2009).

\footnotetext{
${ }^{23}$ Neste caso, alguém inicia uma atividade num espaço de terra virgem, efetuando o seu desbravamento e limpeza e, por longos períodos, exerce sua atividade ou estabelece moradia sem que alguém se oponha ao fato.
} 
Assim, para a aquisição do DUAT o processo acontece da seguinte maneira (ALFREDO, 2009, p. 127-128):

1. Adquire-se o formulário nos respectivos Serviços Provinciais de Geografia e Cadastro (SPGC) da província/distrito onde se localiza o terreno pretendido;

2. Sendo o formulário preenchido e entregue aos serviços de cadastro, efetua-se o pagamento dos custos referentes à deslocação dos técnicos dos Serviços Provinciais Geografia e Cadastro para o reconhecimento e consulta às comunidades locais;

3. É feita uma identificação prévia, o reconhecimento do terreno e o esboço da localização da parcela pretendida, efetuando, em seguida, a descrição do terreno e marcação da data para a consulta à comunidade local;

4. Durante a consulta, participam os Serviços Provinciais de Geografia e Cadastro, o Administrador do Distrito ou seu representante, o Diretor Distrital da Agricultura e os membros da Comunidade Local. O resultado deverá ser redigido a punho e assinado por um mínimo de três e um máximo de nove representantes da comunidade local, bem como pelos titulares ou ocupantes dos terrenos limítrofes. Esses representantes da Comunidade devem ser escolhidos pelos membros desta, durante o processo de consulta;

5. Na sequência, é feita a atualização do esboço de localização e da memória descritiva, bem como o preenchimento do edital, que ficam disponíveis para consultas junto à comunidade e na administração do distrito;

6. Feita a aprovação da comunidade, o requerente submete os documentos obrigatórios exigidos por Lei à constituição do processo, sendo eles: o formulário, os documentos de identificação (B.I./Dire/Estatutos-para pessoas coletivas), esboço de localização, plano de exploração (quando para atividades econômicas e/ou projeto de investimentos devidamente aprovados), ata da consulta às comunidades locais, cópia do edital, guia de depósito e o recibo comprovativo do pagamento de taxa;

7. Reunidas todas as condições e formalidades, os Serviços de Cadastro elaboram a proposta para o despacho da entidade competente.

A questão do DUAT tem levantado sérios debates quanto à possibilidade deste constituir-se ou não um impedimento para o surgimento de um mercado de terras diante do avultado fluxo de investimento no meio rural, especialmente nas atividades ligadas 
à terra. Na verdade, a todos interessados, independentemente do tipo de exploração a ser feita na terra, podem adquirir o DUAT das instituições governamentais responsáveis. Assim, cabe ao governador da província a concessão do DUAT para parcelas de até mil hectares. A decisão será do Ministro da Agricultura quando as parcelas ultrapassam os 1.000 ha e são inferiores a 10.000ha. As que ultrapassam a competência do Ministro da Agricultura ficam a critério do Conselho de Ministros (NOVUNGA, 2006, ROSE, 2014).

Ora, esse debate já vem ocorrendo desde a aprovação da Lei de Terras, quando se afirmava precária na sua concepção. Por um lado, a posição de autores, à semelhança de Ribeiro (2006), considerava que, a forma como a Lei de Terra teria sido concebida, conduzia à instabilidade da estratégia de desenvolvimento da agricultura, que incentiva investimentos estrangeiros no setor, ainda que reconhecesse que a não privatização da terra nunca se constituiu um problema para os interessados no investimento agrícola comercial, diante dos grupos empresariais agrícolas que continuaram em Moçambique mesmo depois da independência, a exemplo dos grupos Entreposto e João Ferreira dos Santos. Por outro, autores como Mosca (2014) consideram que a avultada penetração do investimento em capital mineiro e agrário nas regiões rurais, bem como outra natureza de investimento em atividades referentes ao uso da terra acabam pondo em xeque o cumprimento do princípio de que "a terra é propriedade do Estado e não pode ser vendida, ou por qualquer forma alienada, hipotecada ou penhorada" (MOSCA, 2014, p. 13).

Esses fatos não ficam alheios às concepções governamentais que procuram, de certa forma, proteger os direitos individuais de posse de terra sem, no entanto, excluir a possibilidade da entrada de capitais no país que, no meio rural, dirigem-se especialmente às atividades agrícola e mineira. Não obstante, em 2010 foi criado o Fórum de Consulta sobre a Terra, com o objetivo de "proporcionar uma plataforma onde o governo, setor privado e outras organizações da sociedade civil pudessem debater reformas jurídicas e políticas relacionadas com o setor das terras" (ROSE, 2014, p.1). Dentre os vários debates sobre a terra em curso no âmbito do Fórum, destacamse:

1. O desmembramento das parcelas individuais de terras comunitárias;

2. O direito das mulheres à terra;

3. A proposta de regulamentação que rege os procedimentos envolvidos na implantação de uma cessão de exploração no âmbito do DUAT. 
A proposta de regulamentação comporta objetivos jurídicos, legais e políticos, nomeadamente:

Reforçar o sistema dos direitos de uso da terra (DUAT) e acelerar a emissão dos DUAT, para permitir assegurar aos pequenos proprietários de terra (mulheres e homens) a posse de terra e promover o investimento pelo agronegócio (...). Elaborar e aprovar regulamentos que autorizem as comunidades a envolver-se em parcerias através de arrendamentos ou sub-arrendamentos (cessão de exploração) (ROSE, 2014, p. 1-2).

De acordo com Rose (2014), a proposta foca em uma atribuição temporária dos direitos de uso da terra para efeitos de desenvolvimento, facilitando o investimento e o desenvolvimento de terras pouco utilizadas. $\mathrm{O}$ autor parte do pressuposto de que a Constituição, no seu artigo 109, proíbe explicitamente a venda, hipoteca ou alienação, mas não explicitando diretamente a proibição do seu arrendamento,

(1) A terra é propriedade do Estado. (2) A terra não pode ser vendida, ou por qualquer outra forma alienada, nem hipotecada ou penhorada. (3) Como meio universal de criação de riqueza e do bem-estar social, o uso e aproveitamento da terra é direito de todo o povo moçambicano (MOÇAMBIQUE, 1990).

Diante desse pressuposto, bem como do ponto de vista de que menos restrições governamentais poderiam ativar transações econômicas e estimular o crescimento, Rose (2014), considera que a garantia de posse dos DUAT de longo prazo, com direitos renováveis firmes, iria servir como um bom substituto para a propriedade. $\mathrm{Na}$ sequência, possibilitaria o arrendamento de longo prazo (na verdade, os DUAT já têm essa função nos casos concedidos ou reconhecidos pelo Estado), com limitada intervenção do Estado na definição dos critérios de renovabilidade e transferibilidade, tornando a posse pelo DUAT muito perto dos direitos de "plena" propriedade. $\mathrm{Na}$ verdade, Rose (2014) não se prende na propriedade da terra, em termos técnicos, pelo Estado, afinal, segundo o autor, os mesmos direitos de propriedade, exercidos em vários países do mundo, poucos acarretam à qualidade absoluta de tais direitos dentro de um contexto de países soberanos.

Portanto, o debate em torno da proposta de regulamentos gira em torno da ideia de que, se o país preza por uma política de atração de fluxo de capital para investimentos na terra, então, a proposta de regulamentos estaria destinada à redução do risco que o envolvimento do Estado representa na tramitação dos DUAT?

Vejamos que, pelas explicações sequenciais, muito bem dadas por Alfredo (2009), para a aquisição do DUAT, o ponto seis (6) levanta a necessidade de existência 
de um plano de exploração devidamente aprovado por parte da entidade governamental respectiva. No mesmo plano de exploração, sua conclusão ou evolução é condição para a atribuição do DUAT definitivo, bem como para a transferibilidade da terra. Nesse contexto, segundo Rose (2014, p. 4),

(..) o titular do DUAT não pode prever, com confiança a possibilidade de transferir o seu investimento através da venda a um potencial comprador de qualquer melhoria que tenha efetuado sobre a terra porque a transferência do DUAT está sujeita ao critério de várias entidades estatais (que podem, por exemplo, não permitir a transferência por concluírem que não se esta a cumprir o plano de exploração).

O autor acrescenta que, na verdade, o mesmo plano de exploração representa um risco para o próprio titular na aquisição do DUAT definitivo, pois, segundo Rose (2014, p. 4-5) “(...) o fato de não se encontrar em conformidade com o plano de exploração pode dar origem à renovação do DUAT por parte do Estado, sem direito a qualquer indemnização do Estado pelas melhorias feitas" (grifo do autor).

Os mais bem posicionados em termos de formação, conhecimento técnico, e recursos financeiros para a legalização e exploração da terra de forma mais produtiva tomam precauções que suavizem o impacto do risco com a intervenção estatal, redigindo planos de exploração menos específicos possíveis. Assim, um mercado de terras sem restrições iria funcionar de forma a eventualmente colocar a terra nas mãos dessa pequena "elite sofisticada".

Ora, se para um pequeno grupo a legislação priva o ideal de constituição de um mercado de terra, a não ser que sejam minimizadas as intervenções do Estado, para os detentores de pequenas parcelas de terras, bem como as comunidades detentoras de direitos relacionados à terra comunitária, quer estas estejam ou não formalizados num processo de delimitação ou demarcação que pretenda ceder os seus direitos de uso de terra a um potencial investidor, a legislação os favorece. No primeiro caso, de titulares de pequenas parcelas, a possibilidade destes estarem legalizados e, portanto, com um plano de exploração na forma empresarial, é quase nula. No segundo caso, das comunidades, estas possuem pouca probabilidade de aderirem a um mecanismo de transferência permanente dos seus direitos de terra, tanto que para este grupo existe o compromisso de desenvolverem-se “(...) regulamentos que autorizem às comunidades a envolverem-se em parceria pelo meio de arrendamentos" (ROSE, 2014, p. 12). No entanto, dúvidas pairam quando se trata de deixar a critério do mecanismo de consentimento da comunidade para tal envolvimento. Afinal, segundo Rose (2014) o 
próprio mecanismo de consulta da comunidade na aquisição de terras em nada garante que os membros delegados na consulta à comunidade sejam genuinamente representantes da comunidade.

$\mathrm{Na}$ verdade, várias instituições têm se empenhado na proteção dos direitos comunitários sobre a terra. É o caso da iniciativa para Terras Comunitárias (iTC), que atua para a delimitação e demarcação das terras comunitárias, protegendo os direitos rurais sobre a terra, bem como fortificando a capacidade e garantindo direitos legais de uso da terra em nível da comunidade, em parceria com instituições governamentais e outras organizações não governamentais nacionais e internacionais. $\mathrm{O}$ órgão existe desde 2006 e opera em todas as províncias, à exceção de Maputo e Inhambane (iTC/ NEWSLETTER, 2015).

Não à toa que as pesquisas de campo indicaram que o distrito de Inharrime registra pouca afluência na procura dos títulos do DUAT para os detentores de pequenas parcelas individuais de terra, bem como parcelas de terra comunitárias. A entrevista realizada com o representante dos Serviços Provinciais das Atividades Econômicas foi elucidativa quanto ao nível de legalização de terrenos comunitários e de parcelas individuais dos seus membros. Segundo o entrevistado ${ }^{24}$, o que mais tem se verificado é a procura do DUAT para terras destinadas à habitação, especialmente na vila sede e arredores, bem como nas áreas costeiras, para implantação de negócios turísticos. Nas palavras do entrevistado:

Temos tido muita gente que vem cá se informar a cerca de como legalizar seus terrenos. Mulheres também tem aparecido. Existem muitas mulheres com negócios na área de turismo aqui no distrito, então procuram-nos como forma de proteger seus negócios. Mulheres que trabalham na agricultura, temos sim, mas não posso precisar agora o número, mas a avaliar pela nossa cultura aqui, acho que os homens é que procuram mais legalizar suas terras.

Lembrando que, no geral, a província de Inhambane tem um potencial turístico vantajoso. É um polo de atração turístico de quase toda região da África Austral, constituindo o destino da grande maioria dos visitantes da Europa, bem como dos nacionais oriundos dos diversos cantos do país. Além das ilhas do Arquipélago de Bazaruto, Inhambane goza de praias fantásticas, entre elas as praias de: Zavala, Závora, Baia dos Cocos, Tofo, Barra, etc. Destas praias, a praia de Závora localiza-se no distrito de Inharrime, em um dos mais belos trechos da costa, favorecida pelo seu belo recife

\footnotetext{
${ }^{24} \mathrm{O}$ representante dos serviços de atividades econômicas pediu anonimato, tanto que não se mostrou confortável durante todo decorrer da entrevista, realizada em 06/01/15.
} 
natural adequado ao mergulho, rico em diversidades aquáticas, como baleias e golfinhos. Závora é também conhecida como uma das melhores áreas de pesca em Moçambique.

O secretário do bairro de um dos povoados do distrito ${ }^{25}$ foi mais explícito ao dizer que, nos povoados de sua jurisdição, a legalização de terrenos é quase inexistente:

O governo fala da legalização dos terrenos mas ninguém fez esse trabalho. As pessoas sabem que tem que legalizar. A pessoa fala para eles, amanhã para não criar problemas prepara documento desse seu terreno para você ter o testemunho, qualquer gatuno quando quer te mexer, você vai apresentar esses documentos. Mas a pessoa vai dizer "essa machamba é do meu avô, tratar documento para quê?". Pode haver pessoa que tratou, mas se tratou, fez sozinho sem ninguém saber. Porque o que chateia aqui é a tradição: "esta é minha terra, era do meu avô". Enquanto nem o avô dele fez nada aqui. "Tratar documento sobre meu terreno? Esses documentos aqui não importa. Se alguém quiser trabalhar aqui vem falar comigo". É o que muitas vezes as pessoas dizem.

A secretaria distrital da $\mathrm{OMM}^{26}$ em Inharrime disse que, no âmbito da mobilização junto às mulheres, em uma das tarefas de intervenção da organização é feita a divulgação das leis, especialmente da Lei de Terras e da Família. Nas suas palavras:

A Lei da Família às vezes é fácil eles aceitarem e já começam a perceber que a herança deve ser de todos os irmãos. Mas a Lei da Terra é difícil eles perceberem, mas divulgamos e explicamos as mulheres que nós temos o nosso direito.

Esse é um fato preocupante observado nas comunidades e famílias visitadas. Ainda que não observáveis de forma frequente, ocorrem conflitos de terra entre membros do mesmo grupo familiar, ou mesmo entre famílias vizinhas, devido, especialmente, à cedência de terras a terceiros sem qualquer registro formal sobre o ato. Em consequência, o único recurso que as famílias acabam tendo para a resolução de tais conflitos são os líderes comunitários, ou seja, os madodas. Segundo o secretário do bairro, existem muitas disputas de terrenos entre primos que, em decorrência do processo migratório, ficaram por anos vivendo nas grandes cidades. Com o regresso aos seus povoados, a questão da titularidade resulta em brigas. Nas suas palavras:

Para sabermos a razão das disputas vamos ter com os antigos da zona para saber quem fazia machamba nos tempos. Então os madodas que estão ai, vão dizer "a primeira pessoa a cavar, capinar esse mato, plantar arvores foi pai deste aqui, mas depois apareceu pai deste

\footnotetext{
${ }^{25}$ Entrevista realizada no dia 10/01/15.

${ }^{26}$ Entrevista realizada no dia 07/01/15.
} 
aqui e também fez o trabalho por cima deste aqui". Mas como os dois querem trabalhar aqui vamos dividir no meio. Mas se existirem coqueiros, mangas, já não da para dividir o terreno e fica com quem plantou.

Portanto, constitui um fato que poucas famílias possuem o registro legal das suas parcelas de terra em Inharrime. No conjunto das famílias visitadas em entrevista, das famílias ligadas ao nosso convívio geral (amigos e vizinhos) e da família em que me casei, nenhuma teria feito o registro legal das suas terras, não estando aqui, em questão, o conhecimento ou não da Lei de Terras e a necessidade de legalização das parcelas individuais.

Questionando-se sobre o conhecimento da lei e sua divulgação nos seus círculos comunitários, no geral, as famílias mostraram, de certa forma, estar informadas, ainda que afirmassem existir pouca divulgação sobre a matéria de Leis junto às comunidades. Entretanto, ficou notório o fato de que, das mulheres dos mesmos grupos familiares, bem como daquelas que compuseram o grupo focal estudado, poucas sabiam da existência da Lei de Terras, e quase nenhuma sabia da mobilização e do incentivo feito pelo governo no sentido de as famílias se atentarem para a delimitação e demarcação das parcelas individuais de terra. Na sua grande maioria, as mulheres afirmam ter conhecimento desses aspectos por via dos seus maridos, que são os que mais participam nas reuniões comunitárias. Esse aspecto sustenta a posição de Karina Dulobo (2010), quando afirma que a ausência de políticas e programas coerentes faz com que as mulheres não observem, como traduzidas na prática, as mudanças da realidade para com o controle dos recursos, ainda que estes sejam por elas mesmas produzidos, pelo fato de se imperarem as relações familiares neles, tendo o homem ou mesmo seus filhos e/ou familiares (no caso de mulheres viúvas) a figura central nas decisões e no controle de tais recursos.

De acordo com os dados apurados em campo, as mesmas mulheres, de um modo geral, têm uma participação fraca nas reuniões comunitárias, limitando-se mais aos encontros ligados à sensibilização e mobilização feitos pelos Serviços de Ação Social, bem como pela OMM, na divulgação da necessidade de planejamento familiar, cuidados com doenças de transmissão sexual, especialmente o HIV-SIDA, entre outros assuntos de âmbito social. 


\subsection{O Acesso à Terra}

O campo de acesso à terra nas zonas rurais constitui um dos elementos mais elucidativos das relações sociais no contexto tradicional moçambicano. Uma vez que é o ativo principal na geração de condições que proporcionem o preenchimento adequado das necessidades básicas da maioria da população moçambicana, a terra é o local onde se constroem as habitações, onde se exercem os cultos de adoração aos antepassados, etc., mostrando que, para as comunidades rurais, ela representa um meio de reprodução social mais que um simples recurso produtivo. Nesse contexto, a forma como a terra é adjudicada, controlada e herdada constitui uma das bases mais importantes de socialização que influencia as escolhas dos diferentes grupos sociais (NEGRÃO, 2000).

Não à toa que o mecanismo de acesso à terra tem sido um tema fascinante e de interesse de estudo por muitos autores, dada a sua complexidade no seio das comunidades rurais, na medida em que constitui a melhor via de incursão nas tradições, que podem ajudar a compreender a forma como estas moldam e são moldadas pelas construções sociais que determinam o lugar e a função dos sexos na sociedade moçambicana. Portanto, serão aqui tratadas três formas pelas quais pessoas individuais, especialmente mulheres das comunidades rurais, têm para aceder à terra: o processo de sucessão de geração em geração dentro de uma mesma descendência linhageira, o casamento e o empréstimo.

\subsubsection{Acesso por herança - o exemplo de Esperança}

No caso do critério de sucessão de geração em geração, nas sociedades patrilineares do sul do país, as normas e práticas costumeiras estabelecem que apenas os indivíduos do sexo masculino estão dotados do direito à herança. A terra socialmente representa o lugar físico de coesão do grupo familiar, o elemento de construção de identidade e o local onde são criadas e recriadas culturas e tradições (a reprodução da vida social e individual). Todavia, apenas o homem pode herdar a terra que pertencera aos seus ascendentes. 
Entretanto, A Lei de Terras confere oportunidades e direitos iguais para homens e mulheres no acesso, posse e controle da terra. A Lei da Família 10/2004, preza pelos mesmos princípios de não diferenciação de gênero. A mulher e o homem têm os mesmos direitos no que diz respeito ao casamento, ao divórcio, à guarda dos filhos, bem como à divisão de bens no casamento. A Lei da Família estende a proteção dos direitos da mulher quando exclui a discriminação contra a mulher nas questões de casamentos polígamos, relações estáveis, herança e estatuto da viúva. Ainda que, pelos trâmites legais, não exista distinção entre homens e mulheres, apenas é reservado aos homens o poder de decidir sobre as parcelas a serem atribuídas aos restantes membros da família, como no caso das irmãs e/ou primas que permanecem na família de nascença, bem como daquelas que, por divórcio, separação, viuvez ou outras circunstâncias, regressem do lar e necessitem de terra para dar continuidade às suas vidas.

Segundo Gengenbach (1998), as mulheres (no contexto do seu estudo no distrito de Magude) quase nunca podem herdar a terra ou mantê-la de forma independente ou adquirir direitos de usufruto seguros senão através de uma vida ligada ao casamento. De acordo com essa perspectiva, a romancista Chiziane resgata o sentimento observável em uma mulher que perde a noção de pertencimento em qualquer se seja o grupo familiar, em decorrência desses princípios baseado no homem:

Preciso de um espaço para repousar o meu ser. Preciso de um pedaço de terra. Mas onde está minha terra? Na terra do meu marido? Não, não sou de lá. Ele diz-me que não sou de lá, e se os espíritos da sua família não me quiserem lá, podem expulsar-me de lá. O meu cordão umbilical foi enterrado na terra onde nasci, mas a tradição também diz que não sou de lá. Na terra do meu marido sou estrangeira, na terra dos meus pais sou passageira (CHIZIANE, 2002, p. 92).

Este é um relato feito por uma mulher que acaba se enquadrando na condição de viajante, em que lhe acaba sendo negado o direito de possuir terra, por conta de tradições nas quais o povo acredita e não se coloca na condição de questioná-las.

Ainda assim, esforços de instituições governamentais e organizações de diversas naturezas têm se empenhado para a mudança desse cenário, especialmente no seio da mulher rural em Moçambique. As campanhas de mobilização da OMM visam especialmente a elucidar à mulher seus direitos e as formas de se protegerem perante tais "agressões" (grifo nosso). Segundo a representante distrital da OMM, por vezes, tiveram de intervir junto aos grupos familiares diante de atos totalmente prejudiciais à mulher e da exclusão de alguns grupos na herança familiar. Nas suas palavras: 
Às vezes existem muitas dificuldades de fazeres entender a própria mulher para não desistir de lutar pelo que tem de direito. Muitas vezes tivemos que ir para casa de algumas famílias. Aconteceu no ano passado um caso de dois irmãos em que faleceu os pais. A irmã foi ao lar, voltou do lar e pediu espaço ao irmão que lhe cedeu um pedaço de terra onde ela construiu, plantou coqueiros, cajueiros, mafureiras e outras árvores. Agora que os filhos estão grandes o tio não permitia que eles construíssem nessas terras. Disse que "eles não podem construir aqui. Tem que ir lá a casa dos pais porque esta herança não te pertence porque você é uma mulher"

Casos dessa natureza são bastante comuns nas comunidades rurais em Moçambique. Em uma das tantas conversas com o grupo de autoridades locais, surgiu a questão sobre a forma como eram tratados os conflitos de herança na comunidade, bem como a percepção destes na questão. Era de concordância geral que as mulheres não deviam ter direito à herança, pois, em algum momento das suas vidas, deixariam a casa da família para criar a sua. Nas palavras de um dos líderes comunitários:

Eu, mesmo tendo nascido só mulheres não aceito que estas fiquem com a minha herança. Para quê? Vir um homem de outra família usufruir do que é meu? Prefiro deixar com meus sobrinhos, pelo menos carregam meu nome (sobrenome). Irão cuidar dos bens que deixarei e se ele só comer sem pensar no futuro, me consolo de ser ele e não filho de quem nem sei quem é.

A questão da herança toma dimensões prejudiciais para a mulher. Na comunidade onde sediei a minha observação existem pelo menos cinco casos de mulheres que, por diversas razões, retornaram dos seus lares e ficaram à mercê dos seus familiares homens para a aquisição de terra para residência e trabalho. Em alguns casos, sequer são deixadas construir casas melhoradas para habitação, com a mera justificativa de que essa, a mulher, não faz parte daqueles privilegiados para herdar terras. Pelo que, esse tipo de residência poderá ser motivo de disputas no futuro. O caso contado a seguir espelha um conflito de herança:

Esperança é uma mulher dos seus aproximadamente 68 anos que vive atualmente em terras cedidas pelo seu irmão. A mulher esteve casada e do seu casamento nasceram dois filhos, um casal. Em decorrência da morte do seu marido foi expulsa do grupo familiar do marido, onde recebeu como explicação, o grupo pretender ocupar as terras pertencentes ao casal com outros membros do grupo familiar, uma vez que esta não fazia parte dos beneficiários da herança do marido. A família (pai e irmãos da Esperança) procuraram, na altura, ajuda junto ao poder tradicional uma vez que esta tinha dois filhos menores. Com intervenção deste poder, a condição foi que ela deixasse o filho homem com a família do marido ou que apenas pudesse colher os frutos das arvores por eles plantadas. Teve que retornar a residência dos pais e por anos viveu nessas condições e dessa forma criara seus filhos, na casa dos seus. Entretanto, o filho 
homem de Esperança veio a perder a vida em um acidente de viação na cidade capital de Maputo, sem deixar nenhum herdeiro. Tomando conhecimento da morte do único herdeiro de Esperança e seu falecido marido, a família deste proibiu terminantemente que Esperança retirasse qualquer benefício do que havia construído durante o tempo que estivesse em seu lar. Hoje existe um total desligamento não somente de Esperança, como também dos seus netos, filhos da filha de Esperança com relação ao grupo familiar onde construiu seu único lar ${ }^{27}$.

A expressão de tristeza e de não pertencimento são bem visíveis no rosto desta mulher, afinal, segundo Esperança, desde então, nunca mais pôde dizer "este espaço é meu". A mulher se sente agradecida pelo gesto do irmão, que depois da morte de seu pai teria a cedido uma parcela de terra separada da nyumba como forma de concederlhe uma vida mais autônoma. Ora, observou-se na expressão dessa mulher ausência total de ideias reivindicativas à herança dos bens deixados pelo pai, limitando-se ao conformismo diante da parcela a ela cedida e espirito de agradecimento pelo fato de não ter sido expulsa de casa em decorrência da morte do pai.

\subsubsection{Acesso pelo casamento}

O casamento é a forma que as mulheres têm de aceder à terra em Moçambique. O que muito tem motivado no estudo do campo de acesso à terra no contexto africano é o acesso à terra por via do casamento tradicional, o lobolo. Esta é a forma mais observável nos espaços rurais em Moçambique. O lobolo, como forma de casamento tradicional nas sociedades patrilineares, será a garantia para a mulher obter a terra necessária para a construção de sua residência e para a agricultura. Segundo Gengenbach (1998), o lobolo, pelo menos teoricamente, obriga o chefe do grupo familiar a tomar como uma das suas principais tarefas depois do casamento de um membro masculino de sua família, a procura de uma parcela de terra a ele alocada para a noiva mais recente da família.

$\mathrm{Na}$ verdade, para além de ser um meio de garantia de acesso à terra por parte das mulheres, o ritual do lobolo é tão importante tanto para a mulher como para o homem, pois é um ritual de invocação dos antepassados para evitar a violência, as doenças e

\footnotetext{
${ }^{27}$ Entrevista realizada no dia 10/11/16.
} 
problemas de diversa ordem, tanto que, durante a sua realização, é feita, anteriormente, uma comunicação aos antepassados de ambas as partes em determinado lugar escolhido como o altar da família, como descreve Bagnol (2008, p. 256):

Cedo, pela manhã, no dia do lovolo, a avó paterna (...) fez o muphahlu com vinho branco e rapé na sala de jantar, onde a cerimónia ia ser realizada algumas horas mais tarde. Dirige-se aos espíritos (...) expressando os seus temores e desejos (...). Simultaneamente, realizava-se um muphahlu similar na residência da família do noivo.

Para Gengenbach (1998), tal como para Negrão (2000), no contexto rural, o "lobolo" representa e é a expressão pública de que a família receptora da fillha, garantelhe o acesso à terra para habitação, agricultura e recolecção. A família receptora adjudica a terra ao novo casal da casa, que é constituída pela menor unidade espacial de habitação, produção e consumo da família rural. Além de ser uma unidade espacial, Negrão (2000) acrescenta que ela é também um organismo social de estrutura bemdefinida, no qual se encontra a família rural "regulamentada por leis costumeiras que são aceites por todos" (grifo nosso). O acesso à terra fica, assim, condicionado pelo uso de acordo com o que é determinado pela família receptora, e a segurança de acesso à terra pela mulher será realizada não apenas pela sua inserção ao novo grupo familiar, mas também será garantida quanto maior o número de filhos que ela puder gerar.

Afinal, o lobolo não apenas legitima a mulher como membro do novo grupo familiar, como também aos filhos por ela gerados nesse grupo. Os filhos gerados de um casamento em que ocorre o lobolo pertencem ao pai, vivem com ele e recebem o nome da família do pai. É de concepção geral que filhos homens fortificam e perpetuam o grupo, enquanto filhas mulheres um dia sairão de casa, passando a pertencer a uma nova família. Portanto, o recurso aos filhos homens é a outra opção que a mulher passa a ter para o acesso à terra, o que leva à conclusão de que o fato de ter filhos passa a ser um fator de importância maior, a fim de que a mulher ganhe o acesso aos bens, incluindo a terra.

No caso de filhos de uma mulher não lobolada, estes não podem ser tomados pelo grupo familiar do marido. Pertencem à família da mãe e usam o nome da família desta, podendo, inclusive, viver na aldeia do tio materno. Com essa colocação, conclui-se que o lobolo representa uma instituição forte e incorruptível, pois é um meio de afirmação como grupo social perante o mundo, como mostra Chiziane (2002, pp. 48-49), em seu romance: 
No sul, homem que não "lobola" a sua mulher perde direito à paternidade, não pode realizar o funeral da sua esposa nem filhos. Porque é um ser inferior. Porque é menos homem. Filhos nascidos de um casamento sem "lobolo" não têm pátria. Não podem herdar a terra do pai, muito menos da mãe. [...] Há homens que "lobolaram" as suas esposas depois de mortas, só para lhes poderem dar um funeral condigno. Há homens que "loboraram" os filhos e netos já crescidos, só para lhes poder deixar a herança. Mulher não "lobolada" não tem pátria. É de tal maneira rejeitada que não pode pisar o chão paterno nem mesmo depois de morta.

É fato, como disse uma das participantes do grupo focal (Tereza de 38 anos), que vale a pena contar em primeira pessoa:

Meu lar acabou, meu marido foi à África do Sul e ficou por lá cinco anos sem vir visitar a família. Eu morava com minha sogra e já tinha dois filhos crescidos e este último que na altura ele deixou na barriga. Este nem conhece o pai. Depois de cinco anos ele voltou mas terminou sua viagem em Maputo e lá levou uma mulher para ir ficar com ele na África do Sul. Não foi capaz sequer de visitar-nos em casa. Eu vi que não valia mais a pena continuar no lar. Afinal, nem lobolado ele sequer tinha lobolado. Tínhamos as coisas organizadas para o lobolo. Só faltava o dinheiro que pediram. Então peguei nas minhas crianças, despedi meus sogros e voltei à casa da minha mãe. Passados mais cinco anos, meu marido voltou e veio pedir que meu filho mais velho fosse com ele. Meus pais mandaramno embora com paus. Bateram até os vizinhos virem acudir. Disseram para ele que já não era só o lobolo que queriam, mas também o valor da multa por não ter lobolado, feito filhos em mim e ainda não criá-los. Até hoje nunca mais veio. Os filhos nem querem saber dele. Eu já disse, se quiser, vão. Mas eles dizem, "mama nosso pai e mãe es tu’. Deixa aquele lá.

Logicamente que, casamentos mal sucedidos acarretam consigo graves consequências, principalmente para a mulher e suas filhas. Tais consequências se estendem não apenas junto ao novo grupo familiar, como também à sua família de origem, que fica reticente se, porventura, já tiver feito uso do valor do lobolo, habitualmente expressado como "comer" o dinheiro ou os bois do lobolo. Afinal, dependendo do motivo do não sucesso do casamento, o noivo pode pedir a restituição do que foi cedido como forma de lobolo. Em caso de insuficiência de recursos, a família receptora do lobolo pode ter relutância em aceitar a mulher de volta, uma vez que esta já não está contada entre os que devem ter acesso à terra e outros recursos na família.

Em caso de separação, Gengenbach (1998) acha que as circunstâncias do lar que a recebeu e/ou das relações interpessoais estabelecidas dentro do seu lar com a(s) sogra(s), cunhadas e cunhados, bem como as suas rivais são fundamentais para o seu futuro posicionamento dentro do grupo. Numa situação em que a mulher não tenha 
responsabilidade na separação, esta pode continuar cultivando nas terras do marido, muitas vezes incentivada pelos próprios parentes do marido, que a encorajam para que permaneçam, ela e seus filhos, na casa da família receptora. Entretanto, em caso de divórcio por adultério, esterilidade, mau comportamento e/ou acusação de feitiçaria, a mulher perde o direito de acesso e uso da terra e é devolvida à casa dos pais, onde estes providenciam um espaço para que ela possa produzir. O exemplo mostrado a seguir espelha a situação da perda dos filhos e devolução do dinheiro do lobolo em decorrência da separação:

Aurina, mulher de 41 anos separada do marido, mora e trabalha em terras cedidas pelos seus pais. Devido à sua condição de lobolada, não pode levar nenhum dos quatro filhos gerados no casamento, ainda que menores de idade. Manteve contato com os filhos graças às relações interpessoais boas que desenvolvera com a sogra, que sempre criou condições para que não houvesse um desligamento total entre eles. Entretanto, hoje trabalha e junta o dinheiro que deve devolver em consequência de a ela ser imposta a culpa da separação, sendo esta a condição para que ela mantenha contato permanente e legal com os filhos ${ }^{28}$.

No caso de morte do marido, é sugerida à viúva unir-se com o irmão mais velho dentre os filhos vivos da família, num ritual designado de levirato, e o acesso aos recursos passam a estar condicionados a essa prática, pois subentende-se que poderá se inserir numa nova família receptora via casamento. Tão importante é o ato para o grupo familiar, que a aceitação por parte de quem cabe-lhe a viúva do irmão obriga-o ao abandono dos seus propósitos de vida particular, em resposta ao chamado da cultura e das tradições familiares, tal como o exemplo a seguir:

Tendo que regressar à casa em decorrência do falecimento do seu irmão, o produtor fica com responsabilidade de cuidar de todos os membros residentes na unidade familiar, respectivamente os filhos do irmão, uma irmã do produtor divorciada e a viúva do irmão. Pela sua tradição, como último e único filho homem vivo da família, é quem tem a prerrogativa de herdar e responsabilizar-se pelos bens deixados pela família, incluindo a "guarda" da viúva do irmão, podendo tomá-la para sua esposa. Para tal, é realizada uma cerimônia que junta a família a fim de saber a sorte elou destino que tomará a viúva do irmão (...). Caso a família ou a viúva não concorde com o ato, a viúva é solicitada a abandonar imediatamente a casa, sem direito a nada pertencente ao falecido marido, nem mesmo poderá levar consigo algum dos filhos que pertencem a família do produtor. Entretanto, no caso de consentimento, é preparado o lobolo (...) e a viúva do irmão tornar-se-á sua esposa (CHAMBE, 2012, p. 143-144).

\footnotetext{
${ }^{28}$ Relato retirado do grupo focal.
} 
A prática do lobolo mostra um peso significativo das relações sociais que se abatem sobre as mulheres, definindo a reputação destas perante seus grupos familiares ao mesmo tempo que se apresenta em caráter contraditório. De um lado, subordina a mulher, ao dificultar e gerar mais barreiras para sua emancipação. Afinal, ao aceitar o lobolo, subentende-se um pagamento pela noiva, fato que, no "senso comum", o homem passa até a chamar sua esposa de "a mulher dos meus bois", em decorrência dos bois que teve de ceder para ter a mulher para si (JUNOD, 1987). A aceitação implica também que a mulher deva trabalhar para o marido, ainda que não seja de forma escravizada, o que, de certa forma, impacta na forma de distribuição de terra no grupo familiar, pois, para Gengenbach (1998), a mulher terá o tanto de terra que ela for capaz de cultivar, fazendo com que o objetivo de cada mulher seja cultivar o tanto de tempo que sua estrutura física permitir. Acredita-se, ainda, que o esforço acima dos limites que a mulher desprender no trabalho agrícola, mostrado pelo tempo gasto para produzir, seu empenho e a qualidade da cultura serão critérios avaliadores do seu comprometimento com o lar, também importantes na avaliação da sua reputação, sendo que, facilmente, essas mulheres conseguem manter um casamento saudável e livre de poligamia.

A senhora Khafi é uma mulher de aproximadamente 75 anos. Foi lobolada pela primeira esposa do seu falecido marido, senhor Sautiane, e tornou-se a sua segunda esposa. Entretanto, a primeira esposa de Sautiane, também já falecida, havia a levado da casa dos seus pais na condição de servir de cuidadora dos seus filhos enquanto esta estivesse na machamba. Sautiane, na altura, era trabalhador migrante nas minas da África do Sul. Durante as férias de Sautiane junto à família, este se engraçara com Khafi e engravidou-a. Pelo fato, Sautiane teria que lobolar a senhora e cedéla parte das suas terras. Contrariada, a primeira esposa de Sautiane paga, ela mesma, o lobolo de Khafi e esta se torna esposa de Sautiane lobolada pela sua primeira esposa. Na prática, implicava que o destino de Khafi seria definido pela primeira esposa de Sautiane. Uma vez que esta não pretendia ceder nenhuma parcela de sua terra a Khafi, esta teve que trabalhar nas machambas emprestadas da primeira esposa. Da mesma forma, sendo ela lobolada pela primeira esposa de Sautiane, os filhos desta passaram a pertencer a primeira esposa, tanto que, na prática, dois primeiros de quatro filhos de Khafi, foram registrados em nome da primeira esposa de Sautiane ${ }^{29}$.

Por outro lado, a prática do lobolo, com todas as suas consequências, ampara a mulher, pois, culturalmente, fortifica o sentido de família, na medida em que ela é acolhida por todos os membros e não apenas pelo marido, não importando o local de

\footnotetext{
${ }^{29}$ Entrevista realizada no dia 11/02/15.
} 
residência. Isso marca uma diferença entre a legitimidade ou não de um casamento, bem como fortifica as próprias relações matrimoniais, dificultando sua dissolução, ao envolver todo o grupo familiar para a sua realização. Em caso de casamentos polígamos, o lobolo confere prestígio à mulher. No caso, este representa para ela a “(...) dignidade, a unidade, a aliança. (...). Dá estatuto. (...) a sociedade inteira fica a saber que conta com mais uma mulher adulta, séria, digna, com mais uma família, um lar", como conta em Niketche, Chiziane (2009, p. 90). Tecnicamente, para a dissolução de um casamento em que tenha ocorrido o lobolo, precisa da concentração dos mesmos representantes no ato do lobolo ou representantes correspondentes a cada uma das partes.

A senhora Paula, é uma mulher de 36 anos. Migrou para a cidade de Maputo ainda jovem, onde conheceu seu marido. Paula trabalhava como empregada doméstica e o marido é um empregado autônomo. Por diversas vezes, o marido pedira que ela abandonasse o emprego e fossem morar juntos, perto dos seus familiares, em sua comunidade. O fato de não a ter lobolado foi motivo de recusa, pois o estatuto a ela conferido de mulher lobolada imperava como forma de aceitação pela família do marido. Afinal, não seria apenas uma "intrusa", alguém que pudesse ser descartada sem nenhuma explicação plausível no futuro. Largar um emprego por alguém que sequer havia a lobolado não fazia sentido, na concepção de Paula ${ }^{30}$.

Com todas as suas contradições, a prática do lobolo sofreu e ainda hoje sofre diversas interpretações, sendo a mais comum, a ideia de que não passa de um negócio. Segundo Bagnol (2008), no passado colonial, devido à grande circulação do gado bovino em consequência do lobolo, o governo colonial procurou controlar a prática, estabelecendo um valor a ser pago pelo lobolo como forma de controlar o movimento do gado. Na sequência, tornou obrigatória a comunicação junto à administração e a transferência do gado de um grupo familiar ao outro.

No primeiro governo da FRELIMO, foram tomadas medidas no sentido da eliminação do lobolo, pois foi tomado como um valor retrógado da sociedade tradicional. De acordo com Bagnol (2008), a FRELIMO, além de considerar a prática retrógada, considerava humilhante para a mulher, fato que a colocava como fonte de riqueza, objeto de compra, de herança, como se de bem material se tratasse. Acontece que decorre, durante o ato do lobolo, a entrega, por parte da noiva, do montante de dinheiro exigido pela sua família ao membro familiar, seu protetor, quem possa

\footnotetext{
${ }^{30}$ Relato retirado do grupo focal.
} 
"comer" o dinheiro do lobolo. A foto 7 mostra o momento de entrega do dinheiro do lobolo ao irmão da noiva. Esta cerimônia ocorreu em outubro de 2015.

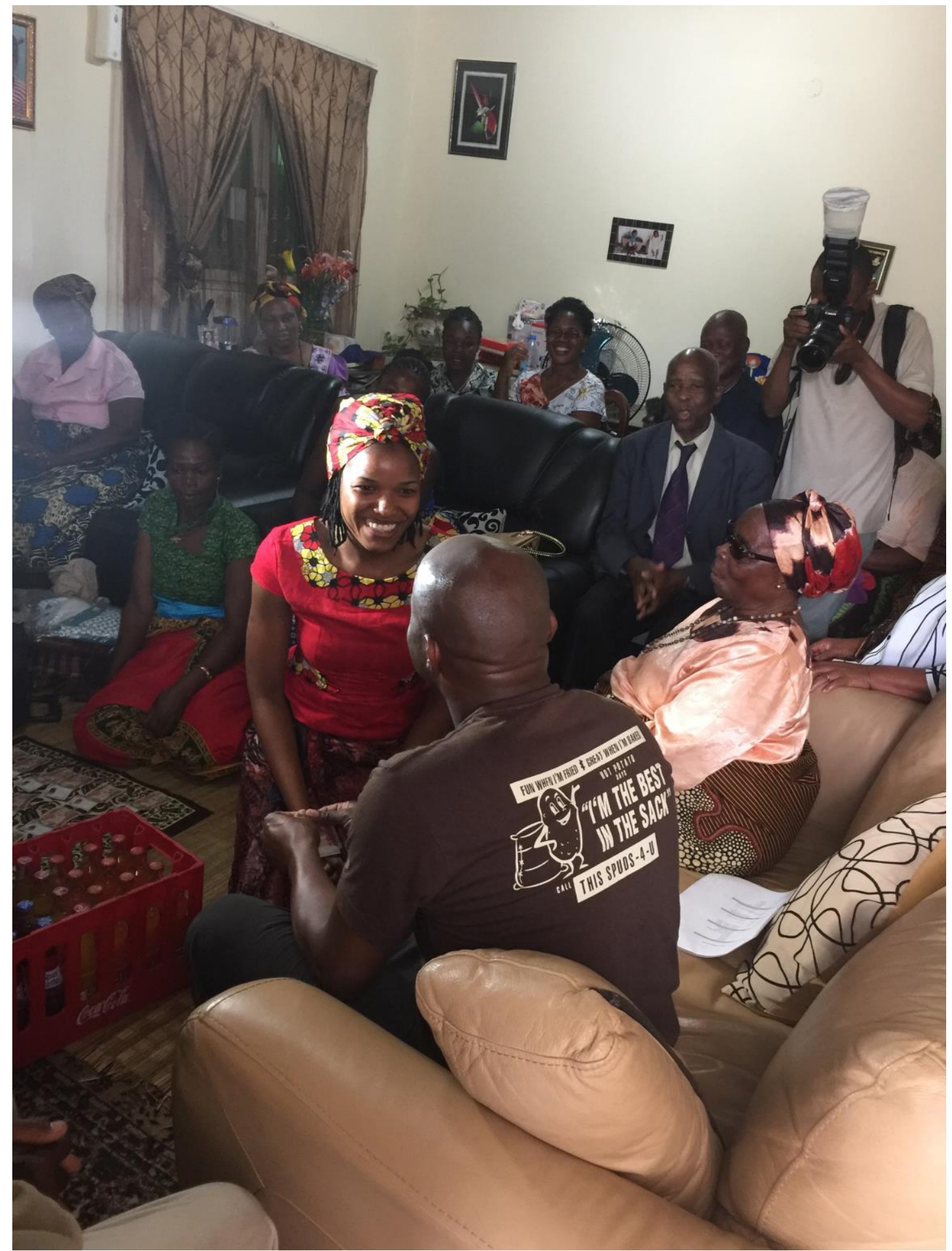

Foto 7. Momento da entrega do dinheiro do lobolo por parte da noiva.

Fonte: A autora

Assim, em 1978, o projeto de lei estabeleceu uma nova concepção a ser observada sobre o casamento: 
O casamento não é um negócio e não se destina a obter em troca qualquer vantagem material para os cônjuges ou seus familiares. $\mathrm{O}$ Estado combate, em particular, a entrega de quaisquer valores ou bens a título de lovolo, gratificação, anelamento ou indemnização (BAGNOL, 2008, p. 254).

Tal como com todas as práticas culturais de referência para a população, o lobolo continuou ocorrendo, principalmente nos meios rurais, onde era, praticamente, a única forma de casamento observável entre a população. Entretanto, progressos foram feitos no sentido de resgatar a prática como uma forma de vida da população, que ficou expresso quando, em 2003, a nova Lei da Família estabeleceu a possibilidade de reconhecer os casamentos religiosos e tradicionais, o que, de certa forma, iria garantir aos casados dentro desse contexto, o acesso aos direitos e obrigações estabelecidas pela lei formal (BAGNOL, 2008).

\subsubsection{Acesso por empréstimo}

O acesso à terra por via de empréstimo ocorre quando um indivíduo ou uma família cede, por entendimento mútuo com um outro indivíduo ou família, uma parcela de terra para exploração durante um determinado período. Essa forma de obtenção de terra gera limitações por parte de quem pede o empréstimo, diante do seu caráter temporário de posse. $\mathrm{O}$ utente de terras emprestadas não pode realizar projetos duradouros em terras emprestadas, como a construção de moradia, plantio de árvores, devendo apenas usá-las para a produção agrícola com culturas de ciclo produtivo curto, para evitar conflitos de terra e benfeitorias no futuro.

Ainda que o empréstimo de terras não dê segurança de posse e nem perspectiva de continuidade, no geral, o empréstimo é a forma estratégica usada por mulheres solteiras, divorciadas e/ou viúvas para o acesso à terra, ou para aumentarem as parcelas em uso. Das mulheres que fizeram parte do grupo focal, várias disseram trabalhar em terras emprestadas além daquelas à elas cedidas em decorrência do lobolo. O motivo por que procuraram por terras adicionais foi a insuficiência de terras para a atividade agrícola, especialmente no momento de pousio da terra. Entretanto, foi interessante o caso de uma, cuja motivação para recorrer a terras emprestadas teria sido o fato de ainda não ter sido lobolada. Segundo esta: 
O marido não lhe dera terra e nenhum outro membro da família o fizera. Ela não pode exigir, pois não foi lobolada e foi por vontade própria morar com o marido, sabendo que este já tinha duas outras esposas. A condição para permanecer na casa seria, então, de trabalhar junto com as outras duas nas suas machambas, ou seja, ajudar alternativamente as duas outras esposas do marido. Sentido que estaria a trabalhar para as outras, tomou a iniciativa de procurar por si terras na forma de empréstimos, onde trabalha e delas tira o sustento para si e seus filhos. Continua exigindo o lobolo, na esperança de um dia poder ter finalmente suas terras para a garantia dos seus filhos ${ }^{31}$.

Essa é uma estratégia de sobrevivência usada por muitas mulheres, especialmente mulheres solteiras, divorciadas, bem como por aquelas que, de alguma forma, precisam aumentar suas parcelas de cultivo como forma de obterem mais autonomia daquilo que produzem.

$\mathrm{Na}$ verdade, o que leva as mulheres a recorrerem ao empréstimo de terras deriva das relações interpessoais que desenvolvem com os "membros de poder" do grupo familiar onde estão inseridas. Posso aqui citar o caso da sogra e da primeira esposa em caso de um casamento polígamo. É fato, e já foi mencionado em outros momentos por Gengenbach (1998), que a entrega da mulher ao trabalho na terra é também um dos requisitos para avaliar a sua dedicação ao lar. Assim, as relações entre sogras e noras, primeira e segunda, ou outras mulheres do mesmo homem são marcadas por cumplicidade ou tensões, especialmente na partilha de terra e nos trabalhos domésticos. Geralmente, as primeiras (sogras e primeira esposa) tendem a manter a nova integrante ocupada em afazeres domésticos pouco visíveis ou perceptíveis quanto ao seu valor, aliados ao trabalho nas suas machambas. Foi o caso de uma mulher integrante do grupo focal, também sogra, que diz adiar a designação parcela de terra da esposa do seu filho, migrante na África do Sul. Como ela diz: "meu filho engravidou e veio deixá-la em casa. Não lobolou e nem nos disse bem se vai ou não ficar com ela. Então, temos primeiro que ver se aguenta ou não trabalhando comigo". Tal estratégia é usada para adiar o quanto possível ceder terra para a nova integrante, bem como limitar a sua entrega e dedicação a um trabalho que possa gerar visibilidade da nova integrante no seio familiar.

\footnotetext{
${ }^{31}$ Relato retirado do grupo focal.
} 


\section{Conclusão}

O capítulo procurou mostrar as particularidades das questões da terra em Moçambique, especificando as formas de acesso, posse e controle existentes no contexto da sociedade moçambicana, concretamente para a mulher rural. Fazendo um resgate do tempo em que o país esteve sob o regime colonial, viu-se que, nesse período, já foram consolidadas a dicotomia de acesso, posse e controle, mediante o reconhecimento da necessidade de respeitar-se às leis costumeiras no que tange à vivência das comunidades locais, bem como a uma certa "elite" referente ao poder tradicional que guia e determina os destinos comunitários.

Em Moçambique independente, ainda que tenham existido mal-entendidos e/ou interpretações errôneas sobre as questões tradicionais e seus poderes, o fato de se prezar por uma visão nacionalista, com privilégios a serem cedidos ao povo, não se podia deixar à parte suas culturas, tradições, hábitos e costumes. Não obstante, por Lei, são, então, reconhecidos os poderes tradicionais e as leis costumeiras no que tange, principalmente, à posse dos recursos naturais.

Ora, pelo que ficou claro no contexto geral da sociedade moçambicana, ainda que se tratando de comunidades matrilineares ou patrilineares, em que a centralidade e o domínio comunitário gravitam em torno do homem, naturalmente, para a mulher, o acesso, posse e controle dos recursos em geral e da terra, especificamente, se mostrará fortemente limitado. Afinal, o homem, ao facilitar o acesso aos recursos à mulher, coloca-se numa situação de vulnerabilidade em relação ao seu poder junto à família, uma vez que, diante da sua condição de ausente em decorrência do trabalho, na prática, ele tem consciência de que a sua condição de chefe da família é algo apenas teórico. Ainda assim, segundo a Lei formal, a mulher é tomada com os mesmos direitos em relação ao homem, ou seja, pode ter para ela a posse e o controle da terra, independentemente do homem.

Bom, se isso é uma verdade, não deixa de ser verdade também que, na prática, as tradições e culturas comunitárias acabam sendo um obstáculo para que a mulher efetive seus direitos, sendo que o trabalho de campo mostrou que poucas mulheres possuem, de fato, o controle dos recursos, entre eles a terra, junto aos seus agregados familiares. 


\section{CONSIDERAÇÕES FINAIS}

Chegou-se à etapa final do estudo: tecer algumas opiniões conclusivas sobre o mesmo. Não pretende-se trazer aqui uma conclusão sobre o tema de acesso posse e controle da terra pela mulher rural, mas sim, mostrar a percepção com que fiquei depois do estudo do tema nesses quatro últimos anos do doutorado e com a pesquisa de campo que realizei junto às mulheres rurais de alguns pontos de Inharrime.

Por sinal, o tema é bastante aberto e inconclusivo. Isto deve-se à complexidade, aos atores sociais e aos interesses envolvidos, especialmente por centrar-se na terra, recurso bastante cobiçado em nível global, no qual projetam-se possibilidades de escassez de alimentos e subida de preços, fato que coloca os países pobres, concretamente os africanos e suas populações, em estado de vulnerabilidade à pobreza e à fome (MOSCA, 2014). Da mesma forma, tem sido nos países africanos onde mais se verificam as corridas para a compra de terras no mundo, daí a importância da terra como recurso produtivo sujeito a polêmicas.

Pensando nesse cenário global e em outros de âmbito local, aborda-se, no início desta tese, o tema da dependência externa da economia moçambicana. Sobre esta temática, a conclusão que tirei foi de que as políticas coloniais, além do açambarcamento das terras aos indígenas e da criação de condições que gerassem dependência para com as poderosas economias vizinhas, por via do envio de mão-deobra barata para o trabalho mineiro, tão pouco preocupou-se, como concluíram diversos autores devidamente citados no trabalho, em criar bases de sustentação da economia moçambicana com um sistema agrícola e industrial autossuficiente. A exemplo disso, falou-se muito da economia do caju. Anteriormente, em meu trabalho de mestrado, abordando a questão dos pequenos produtores de caju em Moçambique, concretamente no distrito de Manjacaze, as pesquisas levaram-me a concluir que a produção agrícola estava voltada mais para o setor de exportação do caju in natura, fato também levantado por vários outros autores. A própria organização da produção atual percebeu-se não ter respondido às demandas de investimento agrícola exigidos, àquela altura, para uma próspera produção do caju que se perspectivava no setor. Refiro-me devidamente no trabalho que 1972 foi o auge da produção agrícola do caju para Moçambique, mas isso teria ocorrido apenas porque o país era dotado de condições climáticas favoráveis: “(...)1970, Moçambique foi responsável pela metade da castanha de caju produzida a 
nível mundial. O ano de 1972 foi representado pelo pico histórico da produção (...), resultado de condições climáticas ideais" (CHAMBE, 2012, p. 36). Na verdade, apenas no âmbito da revitalização do setor é que começam a ser observadas práticas mais modernas de produção. Este exemplo e tantas outras situações mostram a total falta de interesse em investimentos em setores produtivos internos, optando-se por uma economia que trouxe como consequências o afastamento dos homens do meio rural, tornando-os migrantes principalmente para os trabalhos nas minas de ouro sulafricanas.

Moçambique torna-se independente com único legado de devolver aos moçambicanos o que nunca deveria ter saído de seu domínio: a terra, a autonomia, a liberdade, a dignidade, etc. Entretanto, herda as consequências de uma economia dependente, não apenas nos parâmetros econômicos, mas especialmente sobre um povo que tornou as formas de vivências ausentes das suas origens uma cultura, uma forma de vida. Na verdade, estava bloqueado todo e qualquer conhecimento prático e secular da população nativa. A percepção de que o correto, o civilizado, o certo, o humano e o digno vinha do Ocidente e que nele devíamos espelhar-nos e inspirar-nos, fazia com que os homens no campo não observassem o rural moçambicano como um lugar próspero, tanto que vemos, hoje, Inharrime despovoado de homens. Inharrime mostroume que é um distrito de mulheres e crianças. E os Jovens? Estes existem sim, mas prontos e à espera de "voarem" e buscarem novas perspectivas de vida, desde que seja fora dali. E quando voltam, os homens estão prontos para definir e decidir sobre o destino de suas filhas e de suas irmãs que pretendiam ir ao lar ou que voltavam do lar em decorrência de uma separação.

A questão que me coloquei anteriormente foi sobre o papel das mulheres nessas famílias rurais, que acabam carregando-as em suas costas, sendo, assim, o seu fardo e, no entanto, pouco ou quase nada podem decidir sobre elas. Pois bem, a família foi, então, o segundo tema de discussão apresentado no trabalho. Com a discussão desse tema, pude perceber que os contextos de família ou as suas formas estavam impostas pelas percepções do que são as famílias ocidentais. Mostro o grande debate trazido por Adesina (2012), em contraposição ao clássico de Engels (1987), que serviu de base de percepção da origem da família. Aprendi com as leituras e o trabalho em campo que a mulher exercia o poder e um jogo de interesses dentro da sua linhagem. Se antes era tal poder era percebido nitidamente, hoje, arriscaria a dizer, que está sim presente, mas de forma sutil, deixando que o homem expresse suas vontades. Aprendi que o patriarcado 
como modelo de dominação do homem e subordinação da mulher não se fazia sentido pensar na África, em Moçambique. Afinal, a mulher africana tinha o domínio, exercia o poder, dominava os mecanismos de sedução e a sexualidade ocorria em torno dela. $\mathrm{O}$ individualismo do homem com relação à mulher era quase inexistente nas sociedades africanas ou, retirando generalidades, em parte delas.

Mas, se tal como Engels (1987) diz, que com a família surge a propriedade privada e o Estado, estes dois últimos elementos não se compadecem em uma sociedade de domínio feminino. Talvez seria o caso de se dizer que a não aceitação de uma sociedade com tal característica justificaria o repúdio de tais práticas e formas de vida. Assim, vemo-nos, hoje, a repudiar a poligamia, o lobolo, o sororato e o levirato como cultura de determinados povos. É mais prático e fácil dizer que ainda não atingimos o nível de civilização tal que acabaria com o patriarcado. Só não lembramo-nos de mostrar o início e/ou quando ficou definido que o ponto de partida e o ponto de chegada para a tal civilização era o Ocidente. Pois, se começo da África, aliás, onde devia ser, pois foi de onde se descobriu o testemunho da primeira existência humana, então, não estaria atrasada e nem à espera de nada melhor do que sou e tenho para ser civilizada. O civilizado seria o que me representa, o que me identifica, o que nada seria sem ele: a minha cultura e tradição, meus hábitos e costumes, as minhas práticas, vivências e saberes. É essa cultura e tradição que trago e mostro com o exemplo da cultura chope. Trago o que de bonito tem dos resíduos dessa transição de um mundo dominado pela mulher para o mundo dominado pelo homem, que também afetou o povo chope. Hoje, as formas de vida dos povos chopes colocam a mulher em vulnerabilidade e subordinação perante o homem, mas, especialmente, trazem um elemento contraditório perante aquilo que ela acreditava ou acredita ser cultura, tradição, não questionável, porque tem de ser assim. Afinal, por que ser de outro jeito? E de que outro jeito seria? A comunidade a qual pertenço, onde se processam os saberes culturais e professam-se as tradições, identifica-me, representa-me, dela sou parte integrante. Sou membro e não preciso lutar por isso ou qualquer outra forma de colocação. Tem quem me represente, tem quem fale por mim: o homem, enquanto ocupo-me com o que mais justifica minha presença na comunidade, que é a reprodução do grupo. Entretanto, essa mesma cultura e tradição repudia-me quando, tratando-se de um direito, usa-me como elemento de geração de riqueza, coloca-me sempre em segundo plano com relação ao homem.

$\mathrm{Na}$ verdade, a mulher rural apenas esqueceu que o homem e ela mesma estão envoltos nesse mundo capitalista, que aliena o ser humano como tal. Tornou-o 
conquistador e ao mesmo tempo ambicioso. O capitalismo te faz vender até o que na lógica humana não teria espaço para negociação, a terra. Afinal, é da pertença do Divino, ninguém produziu, ninguém transformou. Apenas dispomo-nos dela como recurso para a existência humana sob diversos prismas.

A terra é o tema tratado no terceiro capítulo. Mostra-se como a mulher encontra mecanismos de acesso à terra, recurso de extrema necessidade não apenas para ela, que é a garantia da reprodução social, mas para o grupo como um todo. Afinal, a terra, antes de um recurso produtivo, é um símbolo central na organização das comunidades rurais. É na terra onde descansam os ancestrais, sendo o cemitério de cada grupo familiar o local mais importante da família. As árvores plantadas nas casas servem não apenas para o consumo e uso familiar, mas também podem, em alguns casos, ser o altar da família, onde se reúnem para a tomada de grandes decisões, definição de destinos da vida familiar, discussão de ideias, entre outras demandas familiares.

Irei agora recuar nas questões que levanto na introdução do tema: afinal, qual é mesmo o papel da mulher? Qual o sentido e o valor que dão à vida e à terra? O campo me mostrou que a vida não se escreve na academia. A vida é real, dá-se no nosso dia a dia. E foi isso que as comunidades em Inharrime me mostraram. O dia a dia das comunidades é conduzido pela mulher. É fato que quem dá vida às tradições e culturas, nosso manual de convivência humana e em sociedade, é a mulher. Quem assegura a coesão da casa (nyumba) e da família é a mulher, mas, no final de tudo, o controle real da terra acaba sendo feito sob domínio do homem, quem carrega os símbolos da tradição e da cultura.

Um exemplo vivo e presente disso ocorreu na cerimônia de lobolo a qual tive acesso e possibilidade de assistir mais de perto nesses últimos quatro anos de pesquisa de campo. As mulheres tomavam a frente da negociação. As mulheres foram as que fizeram os rituais de apresentação do restante grupo familiar. Elas que tomavam a dianteira para qualquer ato esperado ou surpreso ocorrido durante a cerimônia. Os homens limitavam-se ao seu silêncio, esperando o aval para procederem com sua parte da cerimônia. No final da cerimônia, cheguei à conclusão de que o domínio feminino perante as relações sociais em torno das tradições e culturas do povo chope continua, pelo menos no mundo rural, ainda que tal domínio se manifeste por detrás da figura masculina. Mas isso pode ser confundido com um simples ato de subordinação e submissão. 
Ora, no final das pesquisas, pude perceber que o lobolo é uma forma primária de acesso à terra pela mulher, que, para complementá-la, tem ainda o recurso ao empréstimo. O empréstimo também é a forma usada por outras mulheres não loboladas, viúvas retiradas do seu direito de permanecer nas terras da família dos falecidos maridos e mulheres divorciadas e/ou separadas que perderam seus direitos no seio da família na qual foi lobolada. Portanto, o acesso à terra não constitui problema no meio rural. O que se percebe como problema é a posse e o controle da terra por parte das mulheres. Então, se por um lado a tradição garante, por via do lobolo, o acesso, esta já não garante-lhe a posse e o controle. Aliás, dependendo da tradição, a mulher nunca teria o direito à posse e ao controle das terras. Entretanto, por outras vias, existem possibilidades de ela garantir a sua segurança, ao menos tratando-se nas formas de transmissão de herança, e com o apoio da lei formal em seu favor.

A propósito da lei formal, com o estudo, pude também concluir que, no meio rural, especialmente nos contextos estudados, de pouco ou quase nada as famílias se beneficiam com a existência de uma lei completa em seu favor para a legalização das terras, não só das que estão em poder da comunidade, mas também das próprias terras familiares. O que mais se mostrou como justificativa para a não preocupação com a legalização foi o suporte na tradição, ou seja, o fato de saberem que as leis costumeiras lhes garantem a posse das terras. Ainda que a própria tradição não saiba lidar com situações de conflitos de terras familiares, a existência frequente de tais conflitos não constitui motivos para que, individualmente, as pessoas procurem o apoio da lei para a proteção dos seus direitos e dos seus herdeiros. Esta seria a única forma que poderia garantir, se não controle, pelo menos a posse e a possibilidade de a mulher usar a lei formal (como a Lei da Família, por exemplo) em casos de expulsão pela condição de viúva ou separação, bem como para o direito de herança das filhas.

Foi dito anteriormente que, de alguma forma, percebe-se a capacidade de barganha da mulher com relação ao homem. Isto deve-se muito ao fato de a maior parte das decisões tomadas pelo homem vir de concertações prévias exercidas em domínio particular, isto é, antes de tomada de qualquer decisão, ainda que familiar, o homem no campo tem o cuidado de exercer uma consulta prévia às mulheres mais idosas da sua família ou mesmo à sua companheira. Da maior parte, senão de todas essas consultas, saem as grandes decisões tomadas pelos homens. As mulheres em Inharrime sabem desse poder que têm em suas mãos, mas pouco uso fazem dele. 
$\mathrm{Na}$ verdade, defendo, em meu argumento central, que o poder está com as mulheres. Este não precisa aparecer por mim, como mulher. Não importa se me coloco na frente ou por trás de um homem, o meu homem. A verdade é que esse seria o caminho certo para uma mudança de cenário no mundo rural: o dia em que a mulher tomar consciência de que, usando esse poder, poderá levar o parceiro a legalizar as terras e, através disso, poderá garantir os direitos dela e de suas filhas à herança. 
ACTIONAID. Estudos de base sobre os direitos da mulher à terra nas províncias de Maputo, Zambézia e Nampula. Maputo: Projeto WOLAR, 2009.MOSCA, João. Economia de Moçambique: Século XX. Lisboa: Instituto Piaget, 2005.

ADESINA, Jimi. Práticas da sociologia africana: lições de endogeneidade e gênero na academia. In: Como fazer ciências sociais e humanas na África: questões epistemológicas, metodológicas, teóricas e políticas. Silva, Teresa Cruz e; Coelho, Joao P.B.; Souto, Amélia Neves (orgs). CODESRIA, Dakar/Senegal, 2012, p. 195-210. ALFREDO, Benjamim. Alguns aspectos do regime jurídico da posse do Direito de Uso e Aproveitamento da Terra e os seus conflitos emergentes em Moçambique. Tese de doutorado. Universidade da África do Sul (UNISA). 2009.

ARNALDO, Carlos. Tendências e Factores Associados à Poligamia em Moçambique. In: Mosaico Sociológico. Org. TELES, Nair; MUIANGA, Bastazar e BRÁS, Eugénio. Maputo: UEM, 2011, p. 194-211.

AVELHAN, Lívia Líria. A presença brasileira na África: um estudo sobre o programa Embrapa-Moçambique. In: Revista Perspectivas do Desenvolvimento: um enfoque multidimensional. Volume 12, número 03, 2014.

BAGNOL, Brigitte. Lovolo e espíritos no Sul de Moçambique. In: Análise Social, vol. XLIII (2.o). 2008, p. 251-272.

CABAÇO, José Luís. Moçambique: Identidade, colonialismo e libertação. Tese de doutorado. Universidade de São Paulo, 2007.

CASAL, Adolfo Yánez. Agricultura de Moçambique Pós-Independência: da Experiência Socialista à Recuperação do Modelo Colonial. In Revista Internacional em Língua Portuguesa, III Série, № 21, Lisboa. Associação das Universidades de Língua Portuguesa, 2008, p. 47-66.

CASTEL-BRANCO, C. N. Dependência de ajuda externa, acumulação ownership. Contribuição para um debate de economia politica. Maputo. IESE, 2011.

Problemas Estruturais do Desenvolvimento Agrário em Moçambique”, Perspectivas Económicas, Maputo, UEM - Fundação Fridrich Ebert, 1994.

CHAMBE, Maria Albertina. Agricultura familiar: sistemas produtivos, comunidade e Estado em Moçambique. Brasília: Rossini Corrêa, 2012. 
CHICHAVA, Sérgio. As economias "emergentes" no setor agrícola moçambicano: leituras, implicações e desafios. In: economias "emergentes": desafios para Moçambique. 2011, p. 371-400. Disponível em:

http://www.iese.ac.mz/lib/publication/livros/des2011/IESE_Des2011_14.EconEm.pdf Acesso em 15 nov. 2015.

CHICHAVA, Sérgio e ALDEN, Chris (Org.). IESE, Maputo, 2012, p. 11-32. Disponível e: http://www.iese.ac.mz/lib/publication/livros/MozChin/IESE_MozamChina.pdf, acesso em: 15 nov.15.

CHIZIANE, Paulina. Niketche: uma história de poligamia. Maputo: Ndjira, 2002. . O Sétimo Juramento. Maputo: Ndjira, 2009.

CLEMENTS, Elizabeth Alice e FERNANDES Bernardo Mançano. Land Grabbing, Agribusiness and the Peasantry in Brazil and Mozambique Agrarian South: Journal of Political Economy April 2013 2: 41-69, doi:10.1177/2277976013477185.

DIREITO, Bárbara P. T. Politicas coloniais de terras em Moçambique: o caso de Manica e Sofala sob a companhia de Moçambique 1892-1942. Tese de doutorado. Universidade de Lisboa, 2013.

DOUGHERTY, J. E. e JR. PFALTZGRAFF. Relações Internacionais: teoria em confronto. Lisboa: Gravita, 2003.

DULOBO, Karina. Estratégias de sobrevivência de um grupo de viúvas organizadas em associação, cidade de Maputo, 2008. In: Outras Vozes, no 29-30, fev.-maio 2010. ENGELS, F. Origem da família, propriedade privada e Estado. Civilização brasileira. 1987.

FERREIRA, A. Rita. Fixação portuguesa e história pré-colonial de Moçambique. Lisboa: CDU, 1982.

GARCIA, Francisco Miguel G. P. P. Análise global de uma guerra (Moçambique 1964-1974). Tese de doutorado. Universidade Portucalense: Porto, 2001.

GENGENBACH, Heid. "I'll bury you in the border!": women's land struggles in postwar Facazisse (Magude District) Mozambique. In: Jornal of Southern African Studies, vol.24, No 1. 1998, p. 7-36.

HERNÁNDEZ, Héctor Guerra. Do Rand à RDA? Modernização compulsória e práticas sociais e estratégias de mobilização social. In: Revista d'Antropologia $i$ investigació social no. 3. 2009, p. 61-83.

ITC/NEWSLETTER. Fundação iniciativa para terras comunitárias (em formação) reúne-se em Tete. In: www.itc.co.mz/news/21, 2015. Acesso em: 04 jan. 2016. 
JAKOBSEN, Kjeld; CARVALHO, Daniela Sampaio de. Da pós-independência ao projeto neoliberal e os desafios para os trabalhadores na África Austral: análise comparativa de Moçambique, Ilhas Maurício e Tanzânia. 2008. Disponível em: Www.global.labour_university_org.unicamp_2008.pdf . Acesso em: 12 fev. 2009.

JOSÉ, André Cristiano. Narrativas da resistência contra as "promessas sem destino": crise da indústria de caju e lutas do quotidiano em Angoche. Dissertação Mestrado em sociologia. Universidade de Coimbra. Disponível em:

https://estudogeral.sib.uc.pt/jspui/bitstream/10316/12978/1/dissertacao_AndreCristian oJose_Abril_2009_.pdf , acesso em: 24 mar. 2011.

JUNOD, Henri A. Usos e costumes dos Bantu. Tomo I: vida social. Maputo: Arquivo histórico de Moçambique, 1996.

LOUREIRO, Gustavo Lapido. Projeto ProSavana: cooperação ou cavalo-de-Tróia? A ambiguidade da presença brasileira na África. Uncategorized. 2012. Disponível em: http://matutacoes.wordpress.com/2012/07/06/projeto-prosavana-cooperacao-oucavalo-de-troia-a-ambiguidade-da-presenca-brasileira-em-africa/. Acesso em: 09 out, 2012.

LOURENÇO, Vitor Alexandre. Entre Estado e autoridades tradicionais em Moçambique: velhas aporias ou novas possibilidades políticas? In: Res-Publica Revista lusófona de ciência política e relações internacionais, n. 5/6, p. 195-207, 2007. LUCE, Mathias Seibel. A economia política do subimperialismo em Ruy Mario Marini: uma história conceitual. In: Anais do XXVI: Simpósio Nacional de HistóriaANPUH, São Paulo, 2011.

MACAMO, E. Da disciplinarização de Moçambique: ajustamento Estrutural e as estratégias neoliberais de risco. In: Africana Studia no 6. Porto, 2003, p. 231-255.

MACAMO, Marcos Efraim. The chopis' journey: restoring identity through theology and mission. Dissertação de mestrado em Teologia. Universidade da África do Sul, 2008.

MACHEL, Samora et al. A Libertação da mulher. São Paulo: Parma, 1979. p. 13-44. (Coleção bases n. 15).

MARINI, Rui Mauro. Dialética da dependência. Editora vozes. Petrópolis, 2000. - A acumulação capitalista mundial e o Subimperialismo. Tradução de Maira Machado Bachir e Fábio Pádua dos Santos. In: outrubro n. 20, $1^{\circ}$ semestre 2012, pp 27-70. Disponível em:

http://www.revistaoutubro.com.br/edicoes/20/out20_02.pdf acesso em: 29 jul. 15. 
MELANI, Carlos R. Aprendendo com a história: críticas a experiência de cooperação Norte-Sul e atuais desafios à cooperação Sul-Sul. In: cadernos CRH. Vol. 25, n. 65. Salvador, 2012, p. 211-231.

MENESES, Maria Paula. O indígena africano e o colono europeu: a contribuição da diferença por processos legais. In: Ex aequo. CES, 2010, p. 68-93.

. Poderes, direitos e cidadania: O 'retorno' das autoridades tradicionais em Moçambique. In: Revista Crítica de Ciências Sociais [Online], 87 2009, colocado online no dia 15 Outubro 2012, criado a 15 Julho 2015 . URL: http://rccs.revues.org/1428; DOI: 10.4000/rccs.1428.

. Mulheres insubmissas? Mudanças e conflitos no norte de Moçambique. In: Ex aequo, no 17. Coimbra, CES, 2008, p. 71-87.

MOÇAMBIQUE. Instituto Nacional de Estatística. Estatísticas do distrito de Inharrime. Maputo, INE, 2012a.

- Governo do distrito de Inharrime. Plano estratégico de desenvolvimento do distrito de Inharrime 2011-2015. Inharrime, GDI, 2012b. - Ministério da Administração Estatal. Perfil do distrito de Inharrime: província de Inhambane. Moçambique, 2005. . Lei da família no 10/2004, de 25 ago. 2004. . Lei de terras n ${ }^{\circ}$ 19/97, de 1 out. 1997. . Constituição (1990).

MOSCA, João. Agricultura familiar em Moçambique: ideologias e política. In: CEsA. WP 127. Lisboa, 2014, p. 34.

. Economia de Moçambique: Século XX. Lisboa: Instituto Piaget, 2005.

NEGRÃO, José. Sistemas costumeiros da terra em Moçambique. In: SANTOS; TRINDADE (Org.). 2000. Conflito e Transformação Social: uma paisagem das justiças em Moçambique. CEA/CES, Maputo/Coimbra, v. 2, p. 10.1-10.43. . Contribuição para história de Moçambique. In: Canal de Moçambique, 82, 83, 84. Disponível em: http://macua.blogs.com/mocambique_para todos. Acesso em: 12 fev. 2009.

NETTO, José Paulo e BRAZ, Marcelo. Economia política. 2012

NIPASSA, Orlando. Ajuda externa e desenvolvimento em Moçambique: uma perspectiva crítica. In: IESE. II conferencia - Dinâmicas da pobreza e padrões de acumulação em Moçambique. IESE, Maputo, 2009. 
NOVUNGA, Boaventura. Reforma agrária e desenvolvimento rural em Moçambique: situação atual e perspectivas. Apresentação em Conferência, FAO. 2006.

OSÓRIO, Conceição e MACUÁCUA, Ernesto. Os ritos de iniciação no contexto actual: ajustamentos, rupturas e confrontos. Construindo identidades de género. Maputo: WSLA, 2013.

PINHO, Osmundo. A antropologia na África e o lobolo no sul de Moçambique. In: Afro-Ásia, no. 43. 2011, p. 9-41.

RIBEIRO, Fernando Bessa. A questão fundiária em Moçambique: dinâmicas globais, atores e interesses locais. Congresso africanista na Covilhã, 2006, p. 15.

ROSE, Ian M. Análise da proposta de regulamentação para a cessão de exploração: um mecanismo viável para ativar o mercado de arrendamento de terras? In: USAID/SPEED. Moçambique, 2014.

ROQUE, Paula e ALDEN, Chris. China em Moçambique: prudência, compromisso e colaboração. In: a Mamba e o Dragão. Relações Moçambique-China em perspectiva. TRAD, Leny A. Bomfim. Grupos focais: conceitos, procedimentos e reflexões baseadas em experiências com o uso da técnica em pesquisa de saúde. In: Physis Revista de Saúde Coletiva. Rio de Janeiro, 19[3]. 2009, p. 777-796.

TVEDTEN, Inge; PAUlO, Margarida e TUOMINEN, Minna. "Se homens e mulheres fossem iguais, todos nós seríamos simplesmente pessoas": Género e Pobreza no Norte de Moçambique. Maputo: Chr. Michelsen Institute, 2009. Disponível em www.cmi.no/publications. Acesso em: 22 jun. 2015.

VALLADARES, Licia. Os 10 mandamentos da observação participante. In: Revista Brasileira de Ciências Sociais. Vol. 22, no. 63. São Paulo, 2007, p. 153-155.

WANE, Marílio. A Timbila chopi: construção de identidade étnica e política da diversidade cultural em Moçambique (1934-2005). Dissertação de mestrado. Universidade Federal da Bahia: Salvador, 2010.

WHITEHEAD, Ann e TSIKATA, Dzodzi. Policy Discourses on Women's Land Rights in Sub-Saharan Africa: The Implications of the Re-turn to the Customary. In: Jornal of Agrarian Change, vol. 3, Nos 1 e 2. 2003, p. 67-112. 